\title{
INFORMATION SECURITY AND IT LAW IN CONDITIONS OF INTEGRATION PROCESSES
}

COLLECTIVE MONOGRAPH

Riga, Latvia 2017 


\section{Reviewers:}

Lutz V.V. - Doctor of Law, Professor, Academician of the National Academy of Legal Sciences of Ukraine, Honored Worker of Science and Technics of Ukraine.

Lipkan V.A. - Doctor of Law, Associate Professor, Academician of the Academy of Sciences of Higher Education of Ukraine, Academician of the International Academy of Personnel.

Information security and IT law in conditions of integration processes: [Collective monograph]. Edited by O. Kharytonova, E. Kharytonov. Riga: Izdevnieciba Baltija Publishing, 2017. $178 \mathrm{p}$.

\section{ISBN 978-9934-8675-2-1}

The categories "IT Law", "Information Security" are examined in the monograph, relations and interaction between these categories are researched. The theoretical basis of determination of the relationship between information security and IT law and the specifics of relations between "IT Rights" and "information security" are being analyzed. The questions are researched in the context of modern integration processes in Europe.

Aimed at scientists, scientific-pedagogical staff of the institutions of higher education, post-graduate students, law students, practicing lawyers. May be of interest to everyone who is interested in the problems of "IT law".

UDC 004.056+340.134:354 


\section{CONTENTS}

INTRODUCTION

4

PART I. THEORETICAL BASIS OF DETERMINATION OF THE RELATIONSHIP BETWEEN INFORMATION SECURITY AND IT-LAW . 7

1. INFORMATION SAFETY( SECURITY) AND IT-LAW . . . . 7

2. INFLUENCE OF „IT LAW" TO PUBLIC CONSCIOUSNESS . . . 20

3. SOURCES OF IT LAW . . . . . . . . . . . . . . 32

4. THE GAPS IN LEGAL REGULATION IN IT-AREA AND ITS OVERCOMING.

5. PREVENTION OF UNLAWFUL TRADEMARK USE THROUGH THE INTERNET: BEST EUROPEAN PRACTICES . . . $5 \mathbf{5 4}$

6. DEBT SECURITY OF THE STATE IN CYBERSPACE UNDER GLOBALIZATION

7. PRINCIPLES OF DCFR AS METHODOLOGICAL BASIS FOR IMPROVEMENT OF NATIONAL CIVIL LEGISLATION.

\section{PART II. SPECIFICS OF RELATIONSHIP BETWEEN IT-LAW AND} INFORMATION SECURITY

87

8. IT TRANSACTIONS AND INFORMATION SECURITY,

87

9. PROBLEMS OF COPYRIGHT PROTECTION FROM INFRINGEMENT ON THE INTERNET.

10. USING THE CONCEPT OF „LOOK AND FEEL” FOR THE PROTECTION THE WEB SITES AS THE OBJECTS OF INTELLECTUAL PROPERTY RIGHTS.

11. MEDICAL SERVICES AND INFORMATION TECHNOLOGY

12. PIRACY IN THE INTERNET - PROBLEM OF IT SPHERE AND INFORMATION SECURITY.

13. PLAGIARISM IN THE FRAMEWORK OF INFOSPHERE . . . 146

14. LEGAL LIABILITY FOR INTERNET COPYRIGHT INFRINGEMENT. 154

15. COMPENSATION OF DAMAGES FOR COPYRIGHT INFRINGEMENT IT-SPHERE. 


\section{INTRODUCTION}

The emergence of information technologies significantly influenced social processes causing the information revolution, formation of the uniform information network etc. Information-communication technologies, in particular, those ones which are connected with the World Wide Web, are sky-rocketing and only in the first decade of the $21^{\text {st }}$ century the number of the Internet users has increased from 350 million to more than two billion. ${ }^{1}$ On this basis a new generation of users - „I-Gen” (Internet Generation) was formed, for them the right for the free access to using any intellectual product in the Internet is the key one.

Generally the role of information-communication technologies in the life of any society is estimated positively which is reflected in Okinawa Charter on Global Information Society adopted by G8 countries in Okinawa in 2000. In Ukraine the main directions of the state policy in the information sphere were determined by the Edict of the President of Ukraine on "Measures on Development of National Component of the Global Information Network Internet and Ensuring Wide Access to the Network in Ukraine" which, in particular, anticipates the improvement of legal regulation of information relations subjects' activity, producing, using, spreading and storing electronic information products, protection of intellectual property rights, increasing the liability for infringement of the stated order of access to electronic information resources of different forms of ownership, intentional spreading of computer viruses etc.

However, as Julian Assange, the founder of Wikileaks states, "computerization of society" may result in the arrival of transnational surveillance anti-utopia where the Internet may turn from a tool of liberation into an extremely dangerous means of totalitarianism. In order to avoid this it is suggested to hide individual space behind the „cryptographic screen" which will prevent authorities from learning individual secrets and using them. That is, the conflict of interests of the state and an individual is suggested to be solved in the way which would guarantee the freedom of the will where it is possible and restrict the anti-utopia offence where the first way is impossible. ${ }^{2}$

\footnotetext{
Ерік Шмідт, Джаред Коен. Новий цифровий світ; [Пер. з англ.] - Львів : Літопис, 2015. - C.10

2 Про майбутнє Інтернету / Джуліан Ассанж Режим доступу: http://interviews.com.ua/ c/612-assange-internet/
} 
In this way it is possible to state the presence of a number of serious problems connected with spreading information-communication technologies in the society, at least part of which may be solved by legal means through regulating relations which are made up in this sphere and coordinating their subjects' interests.

Law is facing difficult tasks in the field of ordering the relations, emerging in connection with the use of information technology and provision of information security, which indicates the state of protection of the vital interests of a human being, society and the state from infliction of damage through incompleteness, untimeliness and unreliability of information used; negative informative influence; negative effects of information technology; unauthorized distribution, use and violation of integrity, confidentiality and availability of information.

Given the topicality of the problem, on September, 5 $5^{\text {th }}, 2016$ the President of Ukraine Petro Poroshenko instructed the Secretary of the National Security and Defense Council Alexander Turchinov to coordinate with Verkhovna Rada the legislative enshrinement of protection of interests in the field of national security in the field of strategic communications and information security of the state.

In addition, on February, 25th, 2017 the President of Ukraine issued the decree №47/2017, which enacted the decision of the National Security and Defense Council „On the Doctrine of Information Security of Ukraine" and approved the aforementioned doctrine.

Given the fact that the solution of the problem of information security may be carried out, in particular, by improvement of the normative-legal base regarding provision of information security, e.g. protection of information resources, combating computer criminality, personal data protection, etc., due attention should be drawn to research contributions of lawyers in this field.

First of all this concerns the „IT Law”, which lately raises great interest of scholars and practitioners, being caused by the needs of the information society, increasing share of legal activity in IT sector, the need to ensure information security of individuals and society in various fields of social life.

The experience from previous scientific research of the authors of this book shows that it is important to not only define the concept and establish the nature of "IT Law", a circle of relations, which it refers to, characteristics of related legal categories, etc., but also to define the system of relations between them. Taking into account these factors the research methodology and the structure of the monograph were defined.

Its authors realize that some of the conclusions are controversial, not all arguments will be recognized well-founded. Some of the provisions were 
deliberately formulated in a provocative way to encourage the interested readers to intensified debate, which, in fact, is the "super task" of the collective of the authors. If such a debate takes place we can consider our task to be fulfilled.

Thank you for your attention!

We are looking forward to the pleasant communication - directly or through information and communication technologies.

Impressions from the book and wishes can express via the email addresses: intelekt.08@mail.ru; a0911@mail.ru.

Most authors may also be reached through their pages on Facebook. 


\section{PART I. THEORETICAL BASIS OF DETERMINATION OF THE RELATIONSHIP BETWEEN INFORMATION SECURITY AND IT-LAW}

\section{INFORMATION SAFETY( SECURITY) AND IT-LAW}

The term "information" denotes many phenomena and has many interpretations. This makes it impossible to establish a common approach to its characteristics. Therefore, further it is advisable to be limited by the simplified definition of this concept as the sum of constructs and choose the one that mat chest he directions of our research.

In general, information is understood as new data that is received, apprehended and evaluated by its user as useful. In other words, it is understood as the knowledge that is received by the user (the subject) as the result of perception and processing of certain data.'

However, we should note that recently the understanding of information (in each case in the field of law) was significantly modernized and liberalized.

The transformation of vision of the gist of information as an object of civil rights was reflected in the modernization of the concept of the Civil Code of Ukraine on this issue. Thus, article 200of the Civil Code of Ukraine of2003 determined that information is documented or publicly announced data about events and phenomena that took place or are taking place in the society, state or environment. The subtext of this norm was the assumption that what is meant is the data, which constitutes real or potential "personal” (as information about a person) or "commercial" value (as information about property status of the individual). ${ }^{2}$ However, the same article 200 of the Civil Code of Ukraine in the wording of the Law of 13.01.2011indicates that information is any knowledge and/or data that may be stored on physical media or displayed electronically.

Therefore, in order for the information to become the object of law it is not required to be of any novelty, value or topicality or to have specific

\footnotetext{
1 https://uk.m.wikipedia.org/wiki/iнформація

2 Цивільний кодекс України: Науково-практичний коментар. Видання третє. - Х.:ТОВ „Одіссей”, 2006. - С. 206-208.
} 
content or form. The most important thing is that it is any knowledge and/or data that can be recorded in any way. An important mentioning appears here regarding the "reflection in the electronic form" which, in fact, serves as the reference to IT-sphere.

Such a concept of information as an object of civil rights eliminates the need of its special characteristic from the civilistic point of view. However, the question about applicability of this definition to the characteristic of information in other branches of law (criminal, administrative, financial, etc.) remains open. It requires a special study by experts in these fields, and therefore is not considered here.

Attention should be drawn to the fact that the mentioned approach complicates the characterization of requirements of information security, as "the subject of security / protection" is understood too widely.

"Information Security" is a multifaceted term ${ }^{3}$, but as the foundation may be taken the definition contained in paragraph 2 of the Section 13 of the Law of Ukraine of 01.09.2007 „On the Basic Principles of Development of Information Society in Ukraine for theyears2007-2015”: „Information security is the state of protection of vital interests of a human being, society and the state in which the infliction of harm is prevented through: incompleteness, untimeliness and unreliability of information used; negative informational influence; negative consequences of application of information technology; unauthorized distribution, use and violation of integrity, confidentiality and availability of information". ${ }^{4}$

In English language the concept of IT security has two meanings: 1) functional safety (safety), meaning that the system correctly and fully implements only those targets, which meet the intentions of its owner, i.e. it operates according to existing requirements; 2)information security (security) as it is, which relates to the safety of the process of technical processing of information and is a feature of a functionally safe system. Such a system should prevent unauthorized access to data and prevent their loss in case of malfunctioning. ${ }^{5}$

In domestic jurisprudence this was reflected in the proposal to consider that information security must take into account not only the threats to the information, but also the threats that come from it, its technologies and products. Thus, in the information relationships... may occur: threats

\footnotetext{
3 Попова Т.В., Ліпкан В.А. Стратегічні комунікації [словник].за заг.ред. В.А. Ліпкана. - К.: ФОПО.С. Ліпкан, 2016. - С.136-139.

4 Див., також: Правова доктрина України : У 5 Т. -Х.: Право, 2013. Т.2. Публічноправова доктрина України / Ю.П. Битяк, Ю.Г.Барабаш, М.П. Кучерявенко та ін.; за заг. ред Ю.П. Битяка. - С. 823-824.
}

5 https://uk.m.wikipedia.org/wiki/ıнформаційна безпека 
related to encroachment on their information resources (mainly on the part that has limited access) and threats that arise during the formation of the environment, the conditions of activity of such subjects. In the first case, the information serves as the object of threats, and in the second - as the tool of their implementation. ${ }^{6}$

The conclusion on the dual nature of the „threats” seems interesting. Being unable to consider here these provisions in detail, we should emphasize that it is not possible to overcome these threats only by the use of technical means. These tools affect only the technical component of IT sphere, ignoring the „social element”, which is represented by participants of IT relationships. But this is not justified, as on this stage of IT development it is the social element that is usually the factor of the violation of information security.

Looking for the effect on this part of IT sphere we should refer to the legal instruments and thus are facing the phenomenon called "IT Law".

Although in recent years the term "IT Law" is widely used to refer to the norms related to IT sphere, the recognized vision of the essence of this phenomenon in domestic jurisprudence is not yet formed.

Herewith, IT law is often referred to as a total of norms which regulate the work on ensuring information activity in the Internet and security of information technologies (that is information security). At the same time IT law is characterized as a multidisciplinary science, as interdisciplinary institution of law?

In this connection it is necessary to notice that the existence of the category of "interdisciplinary institution of law" from the "normative" point of view causes doubt as isolation of such an institution means the existence of a similar category of a higher level - „complex branch of law”.

However, for the separation of the branch "IT law" (again from the „normative point of view") there must be certain conditions: availability of a particular subject, method, principles of legal regulations etc. ${ }^{8}$

Therefore, we should study if "IT relations" can be regarded as an integral subject of legal regulating, that is, as social relations which exist in the legal boundaries and can be influenced by legal norms through particular means (methods).

First of all, we should admit that in the context of researching the peculiarities of the subject of legal regulations in IT sphere such terms as „information relations”, „information-communication relations”, „Internet

\footnotetext{
6 Зубок М.І. Інформаційна безпека в підприємницькій діяльності. - К.: ГНОЗІС, 2015 - С. 60-63/

7 Бачинський Т. Основи IT-права : посібник - Львів : Апріорі, 2016. -- С. 3.

8 Цивільне законодавство України (основні категорії, принципи та концепти) монографія / авт. кол.; за заг.ред. Є.О. Харитонова. - Одеса : Фенікс, 2012. - С. 17-27.
} 
relations" as well as the abbreviation „IT-relations", ${ }^{9}$ which is more correctly to „decode" not word for word but according to its essence - ,informationtechnology relations" are used.

„Internet relations" which are referred to as a part of relations in virtual environment, the participants of which are bearers of subjective rights and duties in the Internet are the most popular as an object of research. ${ }^{10}$ The specific character of these relations is in ambiguity of parties location; difficulties in identifying participants of relations in the Internet; dependence of relations between the Internet participants on the relations with information providers; electronic character of document flow in the Internet; ${ }^{11}$ uncertainty of legal status in the Internet; existence of virtual organizations etc. ${ }^{12}$

Here, it is necessary to note that the use of the term "Internet relations" 13 is not fully correct. Instead, it is reasonable to speak about „relations in the Internet" as the relations which are made in the Internet, are parallel to real relations simultaneously coinciding with them in content. In such a manner virtual relations can be classified according to a substantive criterion similar to real relations. On this ground new relations belonging to different branches: civil, administrative, financial, etc., arise in the digital environment after their regulating by legal norms. Besides, legal relations arising in the case of infringement of rights and duties by the subjects acting in the Internet stay outside their boundaries. They are legal relations of civil, administrative, criminal liabilities.

The absence of substantive entirety of relations in the Internet makes it possible to conclude about the groundlessness of recognizing the existence of "Internet law" as a „mixed" or „complex institution”"14 and moreover, a branch or a sub-branch of law.

Instead, it is reasonable to consider appearing regulative legal relations in this sphere belonging to different branches: civil-legal, administrativelegal etc. As for the term "Internet law”, it may have the right to exist as a legal concept but not more than that.

9 IT-право: проблеми і перспективи розвитку в Україні: збірник матеріалів науковопрактичної конференції. - Львів : НУ „Львівська політехніка”, 2016. - 396 с.

10 Рассолов И.М. Право и Интернет: теоретические проблемы : автореф. дис. ... докт. юрид. наук. - М., 2008. - С. 8.

11 Дмитрик Н.А. Осуществление субъективных гражданских прав с использованием сети Интернет. - М., 2006. - С. 72.

12 Глушков А.В. Проблемы правового регулирования Интернет-отношений : дис. ... канд. юрид. наук. - СПб., 2007. - С. 42-55.

13 Там же. - 198 с.

14 Рассолов И.М. Право и Интернет: теоретические проблемы . - 2-е изд., доп. - М. Норма, 2009. - С. 42-44. 
It should be emphasized that „Internet relations" are only a part of a more general category „IT-relations” which can be understood (at first sight) as the whole totality of social relations which arise in the process (as a result) of creating and using information technologies. Therefore, „IT-relations” are a general category which covers relations made in the Internet as well.

In the meantime they may not always be „informational” in the strict sense of this word. Thus, the sphere of "IT-law" may include a wide range of different relations which are regulated by the norms of civil, economic, administrative legislation. In particular, the sphere of civil-legal regulation includes „IT-relations” providing software and software development services; legal protection of web-pages and content; legal support in setting up IT-business; legal audit of IT-companies; legal services for free-lancers; registration and protection of author's rights and trademark in the Internet; making purchase-sale contracts for a site, domain, brand etc.; legal coverage of Internet-shop activity; creation and registration of legal entities in this sphere; license agreements; protection of rights of intellectual property; information protection etc. ${ }^{15}$

In this way, the category "IT-law” is wider than „Internet-law” as it refers to the relations which are also made outside the Internet.

Clearing up the correlation between IT-relations and information relations, it is necessary to mention the existence of a wide variety of views on nature, object, and peculiarities of these relations in the national legal doctrine. Herewith, the theory of information law as a separate branch of law and a private-legal concept of information relations as an institution of civil law and complex institution of legislation of Ukraine are the most wide-spread. ${ }^{16}$

Supporting the second of the mentioned theories, we will first clarify specific features of the relations which are here the subject of legal regulations and, then we will consider the opportunity of separating of a corresponding institution, branch of law etc. Any efforts of lawmakers to create a branch of law or legislation cannot be successful if different-type relations serve as a subject of regulation. Determining the level of uniformity of IT-relations and information relations, we will point out that, though they have a lot in common, they are not identical.

The correlation between them look like a partial overlapping of circles as not all information relations are „technological” as well as not all

15 Бачинський Т. Основи ІТ-права: Посібник - Львів : Апріорі, 2016. - 136 с.

16 Кохановська О.В. Приватно-правове розуміння інформаційних відносин в Україні // IT-право: проблеми і перспективи розвитку в Україні: збірник матеріалів науково-практичної конференції. - Львів: НУ „Львівська політехніка”, 2016. - С. 202-213. 
„technological” relations are information ones. Consequently, both „IT-law” and information law are not only different categories but they cannot be considered as a class or type. However, it does not prevent us from regarding them as similar legal concepts. Herewith, from this point of view it is possible to state that the concept "IT-law" is wider than the concept „information law” as it covers both the sphere of „informational” and the sphere of „information-technological” relations.

All in all it is possible to make a conclusion about the insufficient considering of the subject of legal regulation as a criterion for differentiating an independent branch of IT-law as a uniform subject of legal regulation in this case is absent. Instead, the totality of relations connected with the sphere of information technologies and related spheres are meant. These relations can be civil, administrative, financial, cooperative etc.

That is why we will try to use one more criterion of differentiating a branch of law - the method of legal regulation in which the grounds (principles), characteristic for a particular branch, are reflected. Herewith, in the most general view the principles of law are defined as leading grounds (ideas) which stipulate the content and direction of legal regulation of social relations. The significance of principles of law is seen in the way that they concisely reflect the most significant features of law and are their quintessence, their "face". ${ }^{17}$ The category of principles is general for objective law on the whole. However, for particular branches of law (legislation) particular principles, the specific nature of which depends on their branch profile, and is determined, in particular, by the method of legal regulation, characteristic for a particular branch and reflected in it, are formed.

So, we will further characterize the method of legal regulation as a criterion of differentiation of branch of law based on the assumption that it is a totality of specific methods of legal influence on the participants of social relations in a particular sphere of the life of society.

The main manifestation of the legal method, as usual, is considered to be the solution with its help to the questions: 1) what the legal status of individuals determined by the legal norm is; 2) with which circumstances (legal facts) the norm of law associates the emergence, change, termination and other transformations of legal relations; 3) in which way the rights and duties of participants of legal relations are determined; 4) what the order of protection of rights and interests of participants of legal relations is.

On this ground the original differentiation of imperative and provisional methods of legal regulation as the main methods of legal regulation which

17 Юридична енциклопедія : в 6 т. / редкол. : Ю. С. Шемшученко (голова редкол.) та ін. К. : Укр. енцикл. - Т. 5. - 2003. - С. 128. 
determine what counts most in the legal status of subjects, in their original legal positions takes place.

The imperative method (method of subordination) is characterized by the fact that the regulation takes place from top downward and is based on power-imperative grounds. As a consequence of peculiar features of the imperative method of legal regulation public-legal branches cover institutions and institutes which function in the "vertical level” of public relations and are based on the grounds of power and subordination of subjects of corresponding legal relations.

The provisional method (method of coordination) is characteristic for regulation on the basis of formal equality, initiative and free action of the participants of corresponding relations. The process of such regulation is influenced by efforts of participants of public relations which are regulated with its help. The peculiarities of private law as supranational phenomenon which consists, primarily, of totality of humanitarian ideas, legal principles, rules and norms which refer to defining the status and protection of interests of an individual (man) are manifested in characteristic features of the provisional method.

The imperative and provisional methods are present in branch methods of legal regulation in different proportions.

Herewith, the method of legal regulation is not always a reliable criterion for differentiation of a branch of law. As IT sphere involves various informational, information-technological, communicative and other relations, which in their essence are horizontal and vertical social links, it is natural that both imperative and provisional methods are used to regulate them.

This fact gives grounds for the conclusion that a particular method for legal regulation of IT relations is absent as well. Instead, depending on the type of relations, which are to be regulated, and certain tasks, civil-legal and administrative-legal methods can be used

It is also assumed that functions of a branch of law i.e. the main directions of influence of legal norms on social relations with the aim of their regulation can serve as criteria for differentiating of this branch of law. Herewith, we differentiate those functions which are common for law as a whole and those which are characteristic for a particular area (specific branch functions).

General legal functions which manifest themselves on the level of a branch of law are: 1) function of informing on the rules of behavior; 2) function of educating the participants of relations (preventive function); 3) function of regulating relations which consists in providing their participants with rights 
and duties, establishing the rules of their behavior; 4) function of protection (compensation of losses etc.).

These functions are characteristic for each branch of law but they acquire specific features due to the subject (sphere of corresponding relations), method of legal regulations and grounds basing on which the aim is reached. Besides, a branch of law fulfills specific functions, which are characteristic only to this branch, as other branches do not have such aims as this one does.

At the same time an attempt to apply this method as well does not lead to a positive result due to the same reason as an inefficient attempt to use the method of legal regulation as the criterion: relations in the IT sphere are too different.

This leads to the conclusion about the ambiguity of considering IT law and similar legal arrays as independent (or complex or any other branches of law), as they do not correspond to such criteria as availability of the original subject and method of legal regulation, special principles and functions.

Summing up the mentioned above, we may conclude that as regarding IT law we actually deal with the attempts to create a complex approach to legal regulation of different relations of information society it is generally incorrect to evaluate the essence and correlation of corresponding regulatory arrays from the point of view of so-called normativist approach.

Therefore, we can make a conclusion that „IT law” as well as „Internet law”, „informational law” etc. do not exist as branches of law. .

Instead we can assume that not „IT law” as a branch of law but „IT legislation", which is applied to relations which appear while using information-communication technologies, is meant. ${ }^{18}$

At the same time the recognition of "IT legislation" does not mean the recognition of „IT law" which does not exist as a separate branch of law from the point of view of „positivism”.

Nevertheless it does not mean that it is impossible to use the term „IT law" as well as there are no doubts as to propriety of the existence of such a phenomenon as „IT law". However the last one has to be characterized not from the point of view of „positivism” but from the angle of „civilizational” approach when law is regarded as a civilizational phenomenon which simultaneously appears as both an element of social-political system and an element of social consciousness.

From these viewpoints law is considered as a concept (conceptus "thought, idea, notion"), that is as a complex of ideas, notions, knowledge,

18 Пестова К.В., Кравчук В.В. ІТ-законодавство: проблеми, пріоритети та напрями розвитку // ІТ-право: проблеми і перспективи розвитку в Україні: збірник матеріалів науковопрактичної конференції. - Л. : НУ „Львівська політехніка”, 2016. - С. 126-127. 
associations, emotions which appear in the connection with the use of the term „law”, accompany and characterize it.

Consequently, from the standpoint of normativist approach „IT law” can be recognized neither as a branch nor as an institution of law (legislation). Only an artificially created totality of norms which regulate different relations in this or that way connected with the creation and application of information technologies can be meant.

However, this situation does not meet the requirements and expectations of the modern information society. It is even possible to consider it as a denial to take on the challenge of nowadays.

The way out of this situation is seen in the consideration of problems in the sphere, we are interested in, from the viewpoint of civilizational and concept approaches. On this basis the concept of "IT law" which can be studied with the help of concept approach as a totality of corresponding legal concepts.

As it is, the creation and recognition of paradigm, which is an alternative to the positions which have become quite popular with the national jurisprudence but do not have corresponding scientific-theoretical grounds, are meant. This approach is expected to provide the opportunity to solve the problems of methodological character which inevitably arise while defining „IT law" on the basis of traditional „normativist" vision of the concept and essence of law.

Besides, from these standpoints "IT law" can be regarded as an academic discipline the subject matter of which is "IT law" as a concept, and also legal concepts which appear and exist with reference to the creation and use of information technologies.

Basing on such understanding of „IT law" it is possible to determine its structure.

As it was mentioned, at present the sphere of "IT law" includes the norms of civil, economic, administrative, criminal, customs, tax law etc. which form it like mosaic creates a certain integral canvas.

Especially many different IT relations appear in the sphere of civil-legal regulation.

In particular, they are:

1) IT contracts on providing software services or software development;

2) IT work contracts with the natural person of an entrepreneur or a programmer;

3) legal support of freelancers;

4) legal audit of IT companies;

5) legal protection of web-pages and content; 
6) registration and protection of the author's rights and trademarks in the Internet;

7) registration of agreement of purchase and sale of site, domain, brand etc.;

8) legal support of the Internet shop activity;

9)creation and registration of legal entities in this sphere;

10)license agreements;

11) protection of intellectual property rights;

12) information protection etc.

Such a variety of relations which are regarded as IT relations creates in practice fundamental inconveniences in finding legislative acts which are applied to regulate this or that kind of such relations; search and systematization of practice files; subsidiary usage of legislatives norms; application of legal analogy etc.

Therefore, we have to determine reference points for establishing a range of norms which can be referred to „IT law”.

In our opinion it is necessary to begin with leaving behind the notion of "IT law" the norms of administrative, criminal, customs, tax law etc., as the mentioned branches, as managerial and protective, refer to (can refer to) different kinds of social relations ensuring their administration and protection. Similarly they may be business, agricultural, transportation, environmental relations etc. It is doubtful that there are enough arguments for referring such „ensuring” branches to the structure of each branch or sub-branch of law which they „serve”. Otherwise such books as „Property Law and Other Personal Rights”, „Intellectual Property Law”, „Mandatory Law”, „Inheritance Law” would have to be excluded from the Civil Code and corresponding articles of law would have to be left behind the branch as relations regulated by the norms found in these books "are served by the norms of administrative, criminal, tax, customs law etc."

In this manner to the sphere of effect of "IT law" it is reasonable to refer only regulatory relations and correspondingly legislative norms which regulate them.

The next step in systematization and structuring of „IT law" must be differentiation of this notion in general and narrow senses.

"IT law" in its general sense refers to the totality of all norms and rules which regulate the activity on the use of information technologies and informational legal activities in the Internet.

The structure of „IT law" in its general sense looks like a relatively integrated system of multilevel form which includes private legal and public legal elements. The necessity of considering private legal and public legal feature of IT relations 
should be taken into account to define the priority of interests (private or public) and, basing on this, peculiarities of methods of legal regulation which are applied. At the same time IT relations, which are public legal in their essence, may be made in the sphere of civil law as well. For instance, these are the relations of civil responsibility for damage caused by violation of civil law in the sphere of IT relations. They do not arise from lawful actions; their subjects, content, grounds and order of their rise and termination are established directly by legal norms. By their nature the mentioned above relations are either organizational or protective and never are regulatory.

Consideration of this circumstance has practical significance as in practice it necessitates regarding the fact that such relations are regulated only by the norms of legislative acts and cannot be changed or terminated if so agreed.

IT relations, connected with the creation and termination of legal entities, intellectual property relations, contractual relations with IT relations subjects involved, inheritance relations etc. belong to private legal sphere of legal regulation. Mostly such relations are regulatory but in some cases they can be accompanied by civil organizational relations (in the field of creation and activity of legal entities). As we speak about the sphere of private law, where the principle „Everything, which is not forbidden by law, is permitted" is in effect, the existence of which is ensured by the provision of an agreement of civil legislative norm significance, it is possible to state that with its help the main array of IT law norms is composed.

Therefore, in its narrow sense „IT law" is regulatory norms (mainly civil legal) which ensure functioning of IT relations.

Before defining the structure of "IT law" in its narrow sense it is advisable to give a caution as to the necessity of differentiation of a group of norms devoted to general provisions of legislation referring to IT law. It is not reasonable to keep the drawbacks of the institutional system where the lack of a general part created numerous disadvantages which were eliminated only after classification of law based on the pandects of Justinian.

The mentioned above makes it possible to define the structure of "IT law" in its narrow sense in the following way:

1) general provisions (norms) of civil law which refer to IT relations (can be applied for regulating IT relations). They include the fundamentals of civil law; provisions on the analogy of law and analogy of right; foundations for creation of civil rights and duties in the sphere of IT relations; self-help and protection of subjective rights; provisions on the objects of civil rights, in particular, on information as such an object; provisions on legal acts; delegation; terms; protection of private non-property rights of the natural person etc.; 
2) provisions of civil law (norms) which refer to subjective structure of IT relations. They include provisions on creation and termination of legal entities; defining types of legal entities and forms of partnerships which can be created to ensure activities in IT sphere; provisions on carrying in IT products as a share in the charter fund; norms that mediate internal corporative relations; protection of rights of corporations;

3) provisions (norms) of civil legislation which refer to the rights of intellectual property. In particular, provisions referring to the definition of information and objects of rights of intellectual property; legal support of software; protection of information and rights of intellectual property; registration and protection of author's rights and trademark in the Internet; legal protection of web-pages and content; provisions on license agreement etc.;

4) provisions (norms) of civil legislation which refer to agreements in the sphere of IT relations. In particular, general provisions on agreements, their conclusion, changes, carrying out, termination and ways of ensuring their proper execution; agreements on providing software services or software development; agreements on dealing with natural persons-entrepreneurs or programmers; agreements on legal support of freelancers; agreements on legal audit of IT companies; agreements on purchase and sale of the site, domain, brand etc.; agreements on legal coverage of the Internet shops activity; concession; license agreements; agreements on joint cooperation in the sphere of IT relations etc.;

5) provisions (norms) of civil legislation which refer to non-treaty agreements in IT sphere. In particular, provisions on announcing awards, contests referring IT products; activity in the sphere of IT relations in the interest of the other person without their mandate; compensation of losses incurred in the sphere of IT relations; return of unreasonably gained (retained) property in the sphere of IT relations etc.;

6) provisions (norms) of civil legislation which refer to inheritance in the sphere of IT relations. In particular, provisions referring to making a will on products of IT relations and its fulfillment; inheritance of intellectual property on IT products, author's rights on them etc.; distribution of inherited rights on IT products among several legitimate heirs; transferring the rights on IT products according to the agreement on succession to property etc.;

7) provisions (norms) of family law legislation which refer to creation of the right of joint property of a married couple on IT products and the right of joint property of family member on such products; distribution of joint property of a married couple on IT products; establishing of the right of property on IT products by the premarital agreement; protection of rights of family members under the legal age in IT relations etc. 
It should be mentioned that the suggested above structure can refer not only to IT law in the narrow sense but other similar normative arrays (e.g. entrepreneurial law, corporation law and others). That is why it is reasonable to differentiate „IT law in special sense". Herewith, the corresponding normative array should include only those norms which refer to the sphere of IT relations; relations of creation and application of software; the Internet relations and some others.

The structure (system) of IT law, which is suggested here, assumes invariability. However, in any case, from pragmatic point of view the creation of such a system is necessary, because a systematic approach facilitates the solution to secure information safety. 


\section{INFLUENCE OF „IT LAW” TO PUBLIC CONSCIOUSNESS}

The pluralism of opinions that is inherent in modern science opens up new vectors of knowledge of law, it is not limited to his appointment as a social regulator. The use of different methodological tools of social science makes it possible to consider the law in the context of its social nature as part social system. On the basis of civilized approach, the right is characterized as a peculiar civilization phenomenon, serving part of the socio-political structure and social consciousness, is part of the human mind and its outlook, reflecting the representation of individuals and society in general on the status of human right and wrong, justice, good and evil, abuse and renewal rights, crime and punishment, cruelty and humanity more. ${ }^{1}$

Before proceeding to the characterization of the impact of IT law on public consciousness is to find out how information technology in the current development of science and technology affect the public consciousness.

Consciousness is a sense of each man's existence and their actions. This is the highest quality that is inherent in the people, which is generalized and focused reflection of reality, constructing imaginary action and predicting outcomes, regulation and self-control of behavior, which has reflected external forms of creative nature and related language. ${ }^{2}$ Human consciousness is a reflection of the information processes.

Social consciousness is the result of human activity depends on social conditions of life, as the realization of the need for a new type of orientation. That social consciousness is a product of social life.

In the course of history within the social consciousness formed and have developed a number of forms: morality, religion, philosophy, art, political consciousness and legal consciousness. Each of these forms has its own specifics and performs a unique role in society.

Public consciousness with the individual forms what is commonly called the spirituality of the individual, society, nation, state, humanity. Social consciousness is unity of sensory system, information and intellectual component that reflects all social life.

Individual and social consciousness are dialectical unity, individual consciousness is formed and developed under the influence of social

Харитонов Є.О. Сутність IT-права (ІТ-право як концепт) // IT право: проблеми і перспективи розвитку в Україні: збірник матеріалів науково-практичної конференції. - Львів : НУ „Львівська політехніка”, 2016. - С. 276.

2 Тимченко В.І. Формування професійної правосвідомості співробітників міліції (проблеми теорії і практики). - К. : НАВСУ ; „ДС” Авангард, 2001. - С. 10. 
consciousness and social consciousness deepens its essence and adds its contents by the individual. The bearer of social consciousness is a society bearer individual consciousness - the individual.

Public consciousness includes common in society ideas, opinions, ideas, illusions and social sense people. Social consciousness reflects the conditions of every day life, needs and interests.

Any object that is socially meaningful if it is an interest in society is reflected in the public consciousness. Information technologies are no exception. In information technology, we mean not only technologized certain models and channels of communication, but also the full range of methods, tools, techniques related to the expansion of global information space. ${ }^{3}$

Scientific progress taking place in the process of self-realization society produces new ways and means to use the information, thus increasing its value. Increasing efficiency gains information, database information society increasingly contribute to effective social development. The information space, which is formed in this way attracts more entities with different status - individual, society, state, and each has its own interest.

Individual interests in the information sphere lie in the realization of human rights for access to information and to use the information for the physical, spiritual, intellectual development and other activities.

Social consciousness is not the mathematical sum of individuals entities that are part of the respective society; They are in constant interaction and develop in parallel, joint and separate forms for each of consciousness factors determining their development.

The public interest does not always intersect with the individual, and hence social consciousness reflects another phenomenon of information technology. Today we are witnessing a qualitative transformation of society based on information technology. At the present stage of civilization public consciousness inherent in globalization processes, humanization, greening, information. This information technologies have significant impact on such changes in mass consciousness.

Modern information technology had led to intense and dissemination of innovative models of social integration, communication, social and political activity, lifestyle, education. ${ }^{4}$

Multiple factors associated with the spread of information technology exert their influence on public consciousness.

\footnotetext{
3 Стефанчук У. Інформаційні технології та їхній вплив на формування громадської думки в Україні // Українська національна ідея: реалії та перспективи розвитку. - 2008. - Вип. 20 - С. 130.

4 Інформаційні технології як фактор суспільних перетворень в Україні: зб. аналіт. доп. / М. А. Ожеван, С. Л. Гнатюк, Т. О. Ісакова; за заг. ред. Д. В. Дубова. - К. : НІСД, 2011. - С. 3.
} 
The spread of Internet resources with objective information on the implementation of various state functions, various registers of legal information, monitoring studies the efficiency of public administration and local self-doubt leads to the formation of a fundamentally new type of public awareness of the society fundamentally new type. The involvement of the masses in government processes through mechanisms of direct democracy (electronic petition questioning the official sites of the state, electronic addresses), access to numbers that reflect the work of individual departments, significant public resonance of actual and possible legislative initiatives - all this defines the modern civil society.

The introduction of modern information technologies in the economy also has considerable importance for the formation of social consciousness. Significant distribution and the relative availability of e-commerce technologies, new technology solutions for business and high-quality processing of old, fixing simple and clear legislation on the use of modern IT in business cause positive changes in the public consciousness, bringing the transition to post-industrial society model.

The spread of IT in education, science, culture also shows the level of public consciousness, bringing the average member of society to the achievements of modern civilization and creating general intellectual level of society.

Information Technology but can be dangerous for the individual and social consciousness subject to abusive or malicious intent.

At the individual level, the dangerous effects of the information space can lead to a change of mind, mental health. You can talk about the degradation of the individual, if forms that reflect the reality are simplified, the reaction became callous and transition to higher needs (self-actualization, social recognition) to lower (physiological, household). There are possible changes in values, lifestyle, reference points, the worldview of the individual. These changes cause antisocial behavior and are a danger to society and the state. ${ }^{5}$

For example, Internet nowadays development is a virtual environment in which composed almost all the types of relationships that exist outside of it, because the Internet is a reflection of real life. Imaginary anonymity and unlimited discretion on the Internet creates the illusion of permissiveness which is often transfered on the behavior in real life.

Information is also possible impact on the level of public consciousness. The negative impact is usually called manipulation of consciousness.

\footnotetext{
5 Жарков Я. Небезпеки особистості в інформаційному просторі// Юридичний журнал. 2007. - № 2. [Електронний ресурс]. - Режим доступу: http://www.justinian.com.ua/article. php?id=2554
} 
In information security refers to the ability of the state, society, social group and individual maintain a certain probability protects information resources and information flows to support their livelihoods, providing stable operation, development and countering information security and threats, negative information influence on individual and social consciousness and psyche of people, as well as computer networks and other technical information sources, develop personal and group skills and the ability to conduct secure, maintain constant readiness for prompt information in the opposition, whoever it may be imposed.

The proper level of information security society is ensured by a complex of political, economic, organizational, cultural and other activities that help implement information rights and interests of the state and its subjects. ${ }^{6}$

The main objectives of the state information security policy can be formulated as: implementation of constitutional rights of citizens, society and the state information; Protection of information sovereignty of Ukraine, the national information resource and the formation of social consciousness; ensuring adequacy of information for decision-making to government agencies, businesses and citizens; due the presence of the country in the global information space. ${ }^{7}$

Despite the growing interest in information security, its specific features (sufficient complexity and high cost of technical protection, the lack of clear criteria for information security, etc.) limit the practical solution to the problem of achieving and maintaining. To solve the problem of information security, according to researchers, is essential not easy development of private security mechanisms, but above all the development of ideology methodological bases for protection that would have to consider not only the prospects of development of information technologies and systems, but also the prospects for the development of special means of implementation threats. ${ }^{8}$ The development of common rules of IT law, combined them with the fundamentals of the state policy in the field of national security and taking into account the social needs help develop a common methodological tools to maintain information security and help protect the public consciousness

6 Сулятицький П.Р. Інформаційна безпека у системі безпеки життєдіяльності // П.Р. Сулятицький, Ю.А. Жвалюк, Ю.І. Грицюк. [Електронний ресурс]. - Режим доступу: http://virt.Idubgd.edu.ua/pluginfile.php/14209/mod_folder/content/0/Кафедра\%20УІБ/ Грицюк\%20Ю.І/2012/8.pdf?forcedownload=1

7 Бондаренко В.О. Інформаційна безпека сучасної держави: концептуальні роздуми / В.О. Бондаренко, О.В. Литвиненко // Стратегічна панорама. - 1999. - № 1-2. - С. 129.

8 Бортник Н.П. Загрози інформаційному ресурсу держави в контексті інформаційної та національної безпек / Н.П. Бортник, С.В. Пєтков // ІТ право: проблеми і перспективи розвитку в Україні: збірник матеріалів науково-практичної конференції. - Львів : НУ „Львівська політехніка", 2016. - С. 36 
from external negative influence, as a major information security threats Law of Ukraine „On national security” calls „an attempt to manipulate public opinion, particularly through the dissemination of false, incomplete or biased her information." Other threats include: signs restricting freedom of expression and access to information; distributing media cult of violence, cruelty, pornography; computer crime and computer terrorism; disclosure of the information is a state secret and confidential information held by the State or to meet the needs and national interests of society and state.

Ukrainian investigators like Bondarenko and O. Litvinenko distinguish such trends in the overall system of information security, legal and regulatory support, which includes the development of relevant legislation, supervise the implementation of the law by law enforcement agencies, judicial protection; organizational and technical support, which discloses a system of measures aimed at prevention of threats to security information resource; Information security risks acceptable only for non-governmental organizations. ${ }^{10}$

As part of the formation and performance of IT law (in all aspects of its implementation) formed mechanisms to protect individual and public awareness of the negative impacts of information security as a part of the information society. Formation of a modern information society is inseparably linked with the establishment of information security regime, secured by appropriate means its content.

Awareness of the importance of information technology in the home and social life plays a primary role in the information society. So we can talk about the formation of information society consciousness. As the A. Kolodyuk formation information consciousness - is a fundamental prerequisite for the use of information and communication technologies in the life of every citizen."

Information carrier according consciousness can divide into the following types:

1) information the human mind, which reflects the attitude of a person to information technology at the household level;

2) information group consciousness that leads to understanding and using certain group of people together information knowledge;

3) consciousness information society - provides a basic understanding of the society about the information sector.

9 Про основи національної безпеки України: Закон України від 19.06.2003 № 964-IV. [Електронний ресурс]. - Режим доступу: http://zakon3.rada.gov.ua/laws/show/964-15

10 Бондаренко В.О. Інформаційна безпека сучасної держави: концептуальні роздуми / В.О. Бондаренко, О.В. Литвиненко // Стратегічна панорама. - 1999. - № 1-2. - С. 131.

11 Колодюк А.В. Інформаційне суспільство : сучасний стан та перспективи розвитку в Україні : автореф. дис. ... канд. політ. наук. - К., 2005. - С. 10. 
Social system includes all phenomena that exist in society, which include right. The right is also a factor that makes swimming in the public consciousness. It is a system of social influence on other elements forming factors acting right during formation of the basic principles and the principles of social life in general.

Legal awareness it is a form of social consciousness, which includes a set of views, feelings, emotions, ideas, theories and concepts and ideas and attitudes that characterize the attitude of individuals, social groups and society as a whole to current or desired law and everything covered legal regulation.

Legal awareness characterizes the attitude of society to the law of society, reflecting his interests.

Legal awareness of society based on historically determined system of social relations - economic, social, political, spiritual - across society. It reflects the legal nature of relationships in society, principles and legal scheme of communication between members of society, the experience of legal action.

Legal awareness society is divided into legal ideology and legal psychology of the level, form and volume reflect the legal life. ${ }^{12}$

Legal ideology of society is a system of legal ideas, beliefs, ideals, principles, concepts that are characteristic of the whole society. Legal ideology justifies and evaluates existing or arising legal relations, law and order. The best reflection of legal ideology is a system of law in the broadest sense.

Legal psychology society encompasses a set of typical social feelings, value relationships, moods, desires or feelings.

Legal ideology should be formed as the process of identifying the theoretical awareness, coordination and harmonization of the various public interests through achieving social compromise. Lawyers, political scientists, economists involved in the development of legal ideology, take into account the specific historical conditions of society, the balance of power, the level of social consciousness, social psychology, the will and interests of both majority and minority, and other factors.

The main social purpose of law is to regulate social relations. All regulatory processes that take place in nature and society can be characterized by the category of organization and regulation, there are dynamic changes in elemental composition and controlled systems in the process of the relationship between the elements of the system. ${ }^{13}$

12 Скакун О.Ф. Теорія держави і права : підручн.; пер. з рос. - Х. : Консум, 2001. - 656 с.

13 Соснін О.В. Правова свідомість як фактор забезпечення засад захисту інформації // Захист інформації. - 2010. - № 1 (46). - С. 10. 
The term „regulation” reflects the dynamics of law, aimed at achieving the legal result of solving situations that require exposure law. The concept of "impact” is broader than regulation because the right to directly affects human consciousness to form a positive attitude, respect and trust in the right direction and to commit lawful behavior, not only regulates social relations.

The functions of law are areas of its influence, which he characterized as a whole, and therefore inherent in each of its elements. A certain area of law, due to its specificity, may have additional special functions, one function can be authorized to use more, and another - less. ${ }^{14}$

The legal impact on the public consciousness is done in the performance (or failure) of social functions by law. Social functions are specific rights perspective, where regulatory and protective functions are combined in a secluded qualitatively similar in social relations, economics, politics and ideology. Right performs general social function of formation of legal values, principles and desired behaviors.

The subject must clearly understand its nature, purpose, basis (through ideology and psychology) and implement it in life by appropriate action (through the behavior of the subject of public relations) for the right to really fulfill its function. For a developed sense of justice result of this interaction is awareness and understanding of the role of law, given its assessment in terms of the eligibility requirements of society, awareness of the need of the current legal system, compliance with laws and so on.

Under the „influence of IT law” to public consciousness means not only regulating effect, and the whole range of effects on the development of new and changing old values, traditions and behaviors. ${ }^{15}$

The impact of law on the public consciousness appears on two levels the level of perception of rights and equal social and legal actions (behavior). It is with these two levels of impact related to different areas of law.

The right provides information about lawful (granted, permitted, prohibited) in individual behavior, contributing to the formation of attitudes, beliefs, ideals, stimulating to lawful behavior. With the right level of perception related information, axiological, psychological and cultural impact areas of law.

Society is a collection of individuals, each endowed with special psychological status. The participation of the individual in social relations

14 Івановський Д.В. Правовий вплив на свідомість як чинник формування правомірної поведінки // Правовий вплив на неправомірну поведінку: актуальні грані : моногр. Миколаїв : Іліон, 2016. - С. 611.

15 Бурдоносова М.А. Правовий нігілізм як форма деформації правової свідомості населення // Держава і право. - Вип. 45. - С. 57. 
involves individual attitudes to existing legal norms, which is not limited to simple devices, but is a complex ratio of performance and impact of existing standards, their perception of rejection, neglect, abuse and so on.

Public relations (occurring within the use of information technology) have a number of attributes, including innovation, high-tech, informality. The specificity of sphere of relations that are the subject of legal regulation of "IT Law" causes and features of the mechanism of influence „IT law" to public consciousness. Thus, within the information directly influence the public consciousness „IT Law” creates a picture of the latest information technology and reflects the attitude of society (the state) to the individual elements of the information society.

Standard Materials of the "IT Law" may be the real source of enlightenment society that will serve as the key to attracting a wide range of business-IT relationship and further development of information technology. An important element of legal enforcement mechanism should be incentives from the state of information technology people (electronic document management, electronic filling of returns, transactions on the Internet, email addresses, etc.). The formation of a positive image of „virtual” relationships in the public mind, their security and prospects, accessibility and convenience is the dominant purpose of influence "IT Law" within the information area of influence.

Value-axiological orientation and direction of influence of the „IT Law” forms in the public mind an idea and calls us to respect the values protected by "IT Law". The peculiarity is that within the legal effect of the "IT Law" such values as information privacy, identity are objectified which is not as obvious and does not directly go out of from human nature. Embedded Information Society values inherent in the existing system of legal values it is the task is facing „IT law” today.

The result of the psychological impact of the image of law becomes law in all the elements together, that it includes, and phenomena associated with it.

Social groups and society as a whole affects the formation of individual psychological installation relatively to the law ${ }^{16}$. Within the social reality of a society divided according to various criteria into groups so that no individuals (members of the social group) should even be familiar with each other. Political, economic and cultural processes in the society create conditions for the formation of the group endowed with a separate legal status (the electorate mass consumer, etc.).

16 Шаравара І.І. Правосвідомість як юридична категорія та іï основні структурні елементи// Науковий вісник Ужгородського національного університету : серія: Право. 2015. - Вип. 33. - Т. 1. - С. 57. 
The transformation of society through information technology into the „smart society" implies the coexistence of both old (traditional) and new (non-traditional) forms of social differentiation that define the range of social expectations, requirements, service jobs. The development of information technology is a catalyst of the process of stratification, virtual communities appear as a new form of social organization in cyberspace (participants in forums and communities in social networks, podcasts Followers news, blog readers, etc.). Distribution of the new society "segments” is inevitable: users, creators of technology options or personal use of them ${ }^{17}$.

Indirect impact of the "IT Law" due to justice to a group of social consciousness also occurs.

Cultural influence the direction of „IT Law" aims to increase the general cultural level of society by the harmonious implementation of new technologies in the life of society initiation to the achievements of modern civilization, using them to enhance the intellectual, moral and spiritual levels of society.

The law uses the power of their regulatory and protective effects on the behavioral level, allowing evaluation of actions of individuals encouraging or disapproving the past. Specificity of "IT law" leads to the following features its impact on the legal consciousness at the behavioral level:

- if we look at progressive law it can encourage the emergence of relations not only providing them with legal protection, but also can generate the latest in real life, suggesting possible participants relations content relationship possible with the latest technology;

- encourages more efficient use of information technology, providing legislative freedom to use new communications capabilities and resources.

The cornerstone of evaluation of "IT Law" is the public attitude, which reflects the efficiency of the legal impact of IT law.

The attitude of society to the need to streamline relations in the field of IT is quite correct attitude corresponds with the most information technology depends on the interest of society in IT. Heterogeneity attitude can be explained by the fact that the scope is very modern, as long as there is no involvement of the global society, as in other areas of private relations.

There are several basic types of perception "IT law" society, conservative, apathetic, hostile.

The mentality of the person being sustainable social existence, is an active member of its legal action. On the one hand, it encourages the subject to perform certain actions to certain moral values, evaluating their actions.

17 Інформаційнітехнології як фактор суспільнихперетворень в Україні : зб. аналіт. доп. / М. А. Ожеван, С. Л. Гнатюк, Т. О. Ісакова; за заг. ред. Д. В. Дубова. - К. : НІСД, 2011. - С. 23. 
On the other - it also acts as a basis rejection of all that is alien, criterion for determining the legal standards of behavior and selection of legal ideas for their implementation in the legal reality.

Legal mentality is different from the legal doctrines, ideologies so that it can never be completely legal and reflexed and formulated, it is always dominated life enshrined in legal entities conditional legal consciousness reflexes of national identity, justice and culture transmitted by the family "blood "ties as generic generic semantic units through all legal nature" century and millennium ${ }^{18}$.

Legal mentality is largely dependent on the subconscious, which is defined by scientists as „the unconscious, a form of mental reflection in which the image of reality and attitude are subject to it as one indivisible whole, which reflects the reality merges with the subject experiences"19.

In view of the marginal sustainability of public opinion focused on avoiding risks of adverse changes conservatism large part of society in terms of formation and development of „IT law” seems logical. Information technology, like anything new, cause prejudice in society, and information security has the highest priority. Information technology, like anything new, cause prejudice in society, and information security has the highest priority. Information security is a state of security is, so it is a property of the system to minimize the threat information. Conservative perception "IT law" hampers its development is directly proportional to the development of most technologies.

The least influential are apathetic attitude - a certain part of the society is ready to enjoy the benefits of creating information technology, not taking care of the prospects of legal regulation of this sphere. Tacit consent to any changes abstraction of assessments and actions have yet neutral color as give rise to abuse by making the right stakeholders in a broad sense.

Considerable importance in the development of "IT-law" a political factor that is often detached from social needs. Lobbying corporations, big business at the state level results in conflict society and state / interstate IT policy. States individually and taken conglomeration attempts to limit using trade agreements „digital freedom”, which is causing an appropriate reaction in society. Thus, the adoption of Anti-Counterfeiting Trade Agreement (ACTA) between the European Union and its Member States, Australia, Canada, Japan, the Republic of Korea, the United Mexican States, the Kingdom of Morocco, New Zealand, the Republic of Singapore, the Swiss Confederation

18 Дмитрієнко Ю.М. Поняття „правова ментальність”: ментальні права первинних та ідеологічні права вторинних суб'єктів правової свідомості та культури. - Режим доступу: http://nauka.kushnir.mk.ua/?p=46431

19 Философский энциклопедический словарь. - 2-е изд. - М., 1989. - С. 58. 
and the United States of America, the fifth section of which is associated with increased provisions relating to the protection of intellectual property in the digital environment, the summer of 2012 had failed under public pressure. European societies fell under the protection of private data, seeing a threat to its safety, not only in this agreement, but agreement on the transatlantic partnership with the US, which includes some provisions ACTA ${ }^{20}$.

The representatives of hostility to regulatory IT sector are the most active part of society. Representatives of the community in most relationships are active participants in the IT sector and do not share views on the need to streamline IT relationship. Among the arguments often called conflict regulation IT sector primary idea of total freedom that pawned at establishing a global network. Functions of the same state in the information sphere should be limited by creating conditions for the harmonious development of information infrastructure ${ }^{21}$.

Thus, the information society actively promotes the development of justice and society, thus prompting the state to establish free access to legal information, information about the activities of state and local governments, facilitating access to public knowledge. But the fact of the facilitation of the access to information does not guarantee that all citizens are aware of their rights and responsibilities in society generally prevailing high legal consciousness ${ }^{22}$. Under the influence of social consciousness IT deviations are also possible, which find their expression in distorted forms of justice legal nihilism, idealism legal, legal infantilism, etc.

Provided that justice is developed, there is awareness and understanding of the role of law, given its assessment in terms of the eligibility requirements of society, awareness of the need of the current legal system, compliance with laws and so on. The opposite is true when justice „affected” legal nihilism. Distorted ideology and psychology are the same behavior determinants carrier deformed conscience.

Legal nihilism is considered the most dangerous and most common form of deformation of justice, so that nowadays he gets aggressive, global nature hinders democratization and state-building ${ }^{23}$.

20 Дмитрієнко Ю.М. Поняття „правова ментальність”: ментальні права первинних та ідеологічні права вторинних суб'єктів правової свідомості та культури. - Режим доступу: http://nauka.kushnir.mk.ua/?p=46431

21 Сосін О.В. Забезпечення інформаційної безпеки держави: теоретичний дискурс. Режим доступу: http://www.niss.gov.ua/vydanna/panorama/issue.php?s=ivtt1\&issue=2004_2

22 Мукомела І. Інформаційне суспільство та його ознаки: теоретико-правовий аспект // Вісник Національної академії правових наук України. - 2015. - № 2. - С. 134.

23 Пінська О.С. Деформація правової свідомості та ї̈ класифікація // Право і безпека. 2011. - № 1 (38). - C. 58. 
Now all signs distortions legal consciousness of society are present to some extent, they find its expression in, for example, making the user agreements and rules without reading the last use of pirated content, global distrust to the e-commerce use anonymity online to commit socially harmful behavior etc.

Not only underestimation of rights, but its reassessment in a form of legal fetishism (exaggeration of the role of legal norms in the implementation of socio-economic, political and other tasks without regard to their actual capacity) and legal idealism (naive belief in the power of law to solve all problems unconditional acceptance of the rights and the lack of criticism toward him) are forms of deformation justice.

The presence of reassessment in respect of „IT Law" appears in unflattering statistics of complaints to the police citizens, became targets of fraud in Internet is often the fault of the victims themselves.

Deformation of legal consciousness is the antithesis of legal culture. The development of „IT Law” and improve the effectiveness of law designed to remedy the situation and increase the level of legal culture of population.

Thus, the transition to an information society it is an important milestone in the future development of civilization. Building information society it is a complex process that involves a move from one type of civilization to another. Global implementation of IT (as a way of forming new relationships) changes the outlook of people, correlating public consciousness. The emergence of socially important relationship leads to the formation of new rules of social life that later become legal.

The law, on the one hand itself is a formal expression of social consciousness, reflecting a society formed ideas and views on various phenomena of reality. On the other hand, the law affects the public consciousness, forming ideas and opinions, perceptions and value orientations of society and prevents the behavior of individuals.

„IT Law" and social consciousness are interdependent, because „IT Law” is a product and reflection of social consciousness, while IT law affects subsequent changes in the public consciousness and the formation of legal culture in the field of information technology. 


\section{SOURCES OF IT LAW}

In the conditions of formation and development of the information society, information technologies (IT) were deeply integrated into the sphere of public life, providing the collection, processing, transformation, accumulation, use, dissemination and protection of information at the local, national, regional and international levels. New information technologies actively penetrate and are widely used in the provision of services, as well as in production, management and various social processes. The Internet occupies a leading place among such technologies as the most information and telecommunication network of the world's common access, which provides ample opportunity for establishing, placing, transferring and accessing to the information, as well as the provision of related information services.

In this way, a diverse range of social relations emerge and exist in connection with the functioning and usage of information technology. These relations are regulated by the methods of both private and public law or by a combination of both of these methods.

Talking about the sources of IT law, first of all, it should be noted that in the general theory of law, the question of determining the essence of the sources of law still remains debatable, due to the existence of different approaches to the understanding of law per se. Thus, representatives of legal positivism associate sources of law with legislative acts promulgated by government and other competent State authorities, which consists of generally binding rules of conduct established and guaranteed by State forced. But supporters of the sociological theory of law view the sources of law in real social relations. According to the cultural (civilizational) approach to understanding the law, the last acts as an integral part of culture, a sociocultural phenomenon.

However, without resorting to scientific controversy as to the understanding of the essence of the sources of law, as well as the correlation between the categories "source of law" and "form of law", we shall only note that we use this term in the formal legal sense as a form of external expression of the will of the legislator and other subjects of lawmaking, as a way of formalization and existence of the generally binding rules of conduct which guaranteed by State forced.

Based on a formal legal understanding of the sources of law, A.N. Parkhomenko distinguishes the following characteristics: 1) publicity (or legal authority)- sources of law are established by subjects of lawmaking and acted in relation to all persons under the jurisdiction of the State; 
2) lawful character - sources of law are legislative acts that legalised or enacted in accordance with the procedure established by law; 3) hierarchical structure - hierarchy of the sources of law by legal force arranged in the order of successive descending levels of force; 4) direct connection with the state - sources of law are promulgated on behalf of the state, or with its permission, the implementation is provided through a system of State guarantees and sanctions'.

The above understanding of the sources of law will respond to the authors concept approach of research of legislation regulating information and communication and related relationships as a kind of „virtual reality."

At the same time, one should agree with the point of view expressed in the scientific literature that the classical normative approach does not correspond to the contemporary tendency of expanding the range of the sources of law, strengthening their role, as well as judicial precedents that actually exists, as well as the necessity to include in the system of Ukrainian law sources both formally fixed (static), and formally unfixed (dynamic) at this moment sources².

In addition, talking about the sources of legal regulation, it should be borne in mind that, based on the universally recognized provisions of the theory of law, the subject of legal regulation is social relations, while the object of legal regulation is any subject of knowledge - material or immaterial. As Yu.I. Grevtsov notes, the subject of legal regulation - these are specific objects, framework, and elements of the object of legal regulation ${ }^{3}$.

Along with the category of "legal regulation" in the legal science is often used the category "legal impact", the question of their correlation also remains debatable. On this occasion, two main points of view are expressed: 1) legal regulation exhausts possible forms of influence of the law to public relations, that is, these categories are identical (S.O. Golunsky, O.A. Lukasheva, L.S. Yavich and others); 2) the concept of "legal impact" is broader than the concept of "legal regulation” (S.S. Alexeev, M.I. Matuzov, O.V. Mickiewicz, M.F. Orzich, Yu.K.Tolstoy, and others).

Supporters of the second approach usually define legal regulation as an influence on the public relations implemented by the whole legal system

\footnotetext{
Пархоменко Н. М. Джерела права: теоретико-методологічні засади : автореф. дис. ... д-ра юрид. наук : 12.00.01 / Наталія Миколаївна Пархоменко. - К., 2009. - С. 12.

2 Дрішлюк А. І. Щодо методології дослідження джерел цивільного права України / А. І Дрішлюк // Наукові праці Національного університету „Одеська юридична академія”. 2013. - Т. 13. - С. 487;Дрішлюк А. І. Поняття джерела права та його форми / А. І. Дрішлюк // Юридичний науковий електронний журнал. - 2014 - № 1. - С. 18.

3 Гревцов Ю. И. К проблеме правового регулирования / Ю. И. Гревцов // Правоведение. 1981. - № 1 - C. 52.
} 
with a view to their systematization, and legal impact - as taken in unity and diversity whole process of the influence of the law to the social life, people's consciousness and behaviour. At the same time, economic, political, and social relations are included in the subject of legal impact; they are not regulated by law, but its influence to them in one or another way ${ }^{4}$.

Sharing this point of view and taking into account that the majority of the information technology relations are connected with the Internet, the following caution should be made. The Internet itself, being the largest IT environment, is the object of legal impact, while the subject of legal regulation includes various social relations arising in connection with the use of the Network and the objects of civil rights involved in it.

Taking all the foregoing into account, let us consider the characteristic of certain groups of sources of legal regulation of relations arising in the sphere of functioning and implementation of IT.

1. Acts of legislation relating to IT. It should be noted that in the Decision of the Constitutional Court of Ukraine in the case upon the constitutional petition of the Kiev City Council of Trade Unions concerning official interpretation of the provisions of part three of Article 21 of the Labor Code of Ukraine (Case of interpreting the term „Legislation”) from July 9, 1998, No. 12-rp/98, was given the interpretation of the term „legislation”, which are covered the laws of Ukraine, international treaties in force, consented by the Verkhovna Rada of Ukraine as binding, as well as resolutions of the Verkhovna Rada of Ukraine, decrees of the President of Ukraine, decrees and resolutions of the Cabinet of Ministers of Ukraine approved within the limits of their competence and in accordance with the Constitution of Ukraine and the laws of Ukraine. In this regard, it should be pointed out that only legislative and secondary legislation acts of Ukraine will be considered further.

This kind of fundamental act is the Constitution of Ukraine that guaranteed human and citizen rights and freedoms which identify the legal status in the information environment, including the sphere of information technology. Under the Article 34 of The Fundamental Law of Ukraine guarantees the right to freedom of thought and speech, and to free expression of his views and beliefs. Everyone shall have the right to freely collect, store, use, and disseminate information by oral, written, or other means at his discretion. The exercise of such rights may be restricted by law in the interests of national security, territorial integrity, or public order, for the purposes of preventing disturbances or crimes, protecting the health of the population, protecting the reputation or rights of other

\footnotetext{
4 Матузов Н. И. Теория государства и права : учебник /Н. И. Матузов, А. В. Малько. - М. : Юристъ, 2004. - С. 230.
} 
persons, preventing the publication of information received confidentially, or supporting the authority and impartiality of justice.

In addition, because of the emergence and usage of modern information and telecommunication technologies, the provisions guaranteed by Articles 31 and 32 of the Constitution of Ukraine acquire substantive significance. These articles guarantee the rights of privacy of correspondence, telephone conversations, telegraph, and other communications, and also establish a prohibition on interference in private life and family matters, except when such interference is stipulated by the Constitution of Ukraine. The collection, storage, use, and dissemination of confidential information about a person without his consent shall not be permitted, except for the cases determined by law and only in the interests of national security, economic welfare, and human rights. Everyone shall be guaranteed judicial protection of the right to rectify unauthentic information about himself and members of his family, the right to demand the expungement of any type of information, as well as the right to compensation for material and moral damages caused by the collection, storage, use, and dissemination of such unauthentic information.

In regard to invention, establish and further use of IT products, it is necessary to note Article 41 of the Constitution of Ukraine, according to which everyone shall have the right to own, use, or dispose of his property and the results of his intellectual and creative activity.

Inasmuch as the norms of The Fundamental Law of Ukraine are just the basis for regulating social relations arising in the State further regulation of the relevant groups of relations takes place at the level of individual acts of special legislation.

The definition of a possible range of such special legislative acts depends, in its turn, on which relations should be included in the subject of IT law regulation. As for the definition of the legal nature of these relations, different points of view are expressed in legal doctrine. Analysis of these positions allows us to conclude that some scientists (Y.E. Bulatetskii, A.B. Vengerov, V.O. Kopylov and others) proceeding from the general theory of legal relations extract such type of legal relationship as information-legal relations or even narrower category - legal relations on the Internet.

In the opinion of V.O. Kopylov, unilateral and peculiarities of information relations are identified by the peculiarities and legal properties of the objects, concerning which or in connection with which they arise, namely: information and informative objects, information technologies, ways to ensuring, communications and telecommunications means. The specifics of information relations are reduced to the fact that they arise, develop and terminate in the information sphere in the course of information turnover; 
express the state policy of recognition, observance, and protection of information rights and freedoms of human and citizen in the information sphere; reflects the peculiarities of the application of the public law and civil law methods of legal regulation in the implementation of information rights and freedoms, taking into account the peculiarities and legal properties of information and informative objects ${ }^{5}$.

Other scientists have different point of view on the traditional concept of the theory of law and introducing a new concept of „internet relations”, understanding under it the virtual relations that arise on the Internet and are regulated by the rules of law and ethics.

Summarizing the above, we can note, that at the level of doctrinal research, there are no attempts to distinguish and extract the relationship arising in the sphere of information technology - so-called „information technology" relations. The latter are either blurred within the framework of information relations or are identified with Internet relations. At the same time, the Internet as an information and telecommunication system is only one of the IT environment, while information technologies have a wider application and implementation.

At the same time, one should pay attention to the fact that in the most general form relations that arise in the sphere of IT functioning, in their legal nature are heterogeneous and depending on the subject and object composition, substantive content, methods, and principles of legal regulation can be civil, economic, administrative, financial, corporate, etc. In this case, the range of the sources of IT law is unjustified expands, including also the norms of administrative legislation (on the determination of the legal competence of public authorities on the formation and use of information resources, e-governance); tax legislation (on the taxation in the IT sphere); criminal legislation and legislation on administrative offenses (in terms of establishing a system of cyber security and responsibility for violations of the information sphere); labor legislation (concerning the regulation of labor relations in the IT sphere) and other.

At the same time, one should agree with the position expressed in the literature that the majority of social relations that are formed, developed and implemented on the Internet are included in the subject of civil law regulation ${ }^{6}$. Pursuing the goal of defining the range of information

5 Копылов В. А. Информационное право : учебник / В. А. Копылов. - 2-е изд., перераб. и доп. - М. : 2002. - С. 37.

6 Малахов С. В.Гражданско-правовое регулирование отношений в глобальной компьютерной сети Интернет :автореф. дис. на соискание ученой степени канд. юрид. наук : спец. 12.00 .03 „Гражданское право; предпринимательское право; семейное право; международное частное право" / С. В. Малахов. - М., 2001. - С. 13. 
technology relations as the subject of IT-law, it is necessary to assume that the majority of such relations are civil in their legal nature(property and nonproperty), arise about different objects of civil rights (results of intellectual and creative activity, works and services in the IT sphere, etc.) and are based on the principles of legal equality, goodwill and property independence of their participants.

Taking the foregoing into consideration, among the special legislative acts in the IT sphere it is expediently to extract two following groups: 1) those that are fully devoted to the regulation of informatization issues, the development of the information society, the establish and application of information systems, their networks, other information technologies (in terms of the regulation of information technology relations); 2) those that include special norms concerning the functioning and use of IT.

Among the legislative acts of the first group we should note the following: The Law of Ukraine of 02 October 1992 No.2657-XII „On Information”, The Law of Ukraine of 25 June 1993 No.3322-XII „On the Science and Technology Information”, The Law of Ukraine of 05 July 1994 No.80/94-BP „On Protection of Information in the Information and Telecommunication Systems", The Law of Ukraine of 04 February 1998 No.75/98-BP „On the Concept of the National Informatization Program", The Law of Ukraine of 04 February 1998 No.74/98-BP „On the National Informatization Program”, The Law of Ukraine of 18 November 2003 No.1280-IV „On Telecommunications”, The Law of Ukraine of 09 January 2007 No.537-V „On the Basic Principles of the Information Society Development in Ukraine for 2007-2015" and other.

The provisions of these legislative acts concern both information and information technology relations. Thus, the Law of Ukraine „On Information” governs the relations of the creation, compilation, receipt, use, dissemination, protection and defence of information; comprises determining the base term „information” and basic principles of information relations. The Law of Ukraine „On the Concept of the National Informatization Program” defines informatization as a set of interconnected organizational, legal, political, social and economic, scientific and technical, the production processes directed to the creation of conditions for the satisfaction of information needs, the exercise of the rights of citizens and society on the basis of creation, development, use of the information systems, networks, resources and information technologies which are created on the basis of the application of modern ADP and communication equipment. In accordance with Article 1 of the Law of Ukraine "On the National Informatization Program", information technology is purposeful organized set of information processes with the use of computer facilities that provide high-speed data 
processing, quick search of information, dispersion of data, access to information sources irrespective of the place of their arrangement. The legal framework for operation in the telecommunications sphere, including the activities of operators of Internet services, is established by the Law of Ukraine „On Telecommunications”.

Besides, a special place in this group is occupied by legislative acts aimed at ensuring electronic document flow and regulation of e-commerce relations, namely, The Law of Ukraine of 22 May 2003 No.851-IV „On Electronic Documents and Electronic Document Flow", The Law of Ukraine of 22 May 2003 No.852-IV „On Electronic Digital Signature” and The Law of Ukraine of 03 September 2015 No.675-VIII "On Electronic Commerce”. The adoption of the latter became a notable event considering the active movement of part of the economy and business into the global environment of the Internet. Due to a number of advantages and opportunities to quickly solve the tasks, Internet technologies are actively used by commodity producers and suppliers to promote, advertise, offer and sell their goods to end users.

Talking about the norms of the law regulating public relations in IT sphere of Ukraine, A.M. Novitsky, notes different types of formation of legal norms: that historically formed (The Law of Ukraine „On Information”; that were adopted at the request of the international community (The Law of Ukraine „On Electronic Digital Signature”, The Law of Ukraine „On Electronic Documents and Electronic Document Flow") and those that are adopted at the request of the development of the industry (The Law of Ukraine „On the National Informatization Program") ${ }^{7}$.

As for the second group of legislative acts containing special norms that are applicable to relations connected with the operation and use of IT, they are mainly codified. Considering the definition of the legal nature of information technology relations as an object of IT law, this basic codified act is The Civil Code of Ukraine.

Thus, the provisions of the Book IV „Intellectual property right” and Chapter 75 of Section III,Disposition of intellectual property rights" have particular significance for the regulation of the IT sphere. Objects and subjects of intellectual property law, the rights of participants, basic principles of protection and defence of intellectual property rights, civil law contracts that determine the use of objects of intellectual property law and disposition of property rights to these objects are fixed in them. In addition,

7 Новицький А. М. Місце IT-права в загальній системі інформаційного права / А. М. Новицький // IT право: проблеми і перспективи розвитку в Україні: зб. матер. наук.практ. конф. (м. Львів, 18 лист. 2016 р.). - Львів: НУ „Львівська політехніка”, 2016. - С. 117. 
the provisions of Section II „Persons" of the first book of the Civil Code of Ukraine are applied to the regulation of relations arising in connection with the foundation and activities of companies in the IT-sphere or realization of such activities on the basis of self-employment. The provisions of Chapter 62 "Implementation of Research, Development and Technological Work”, Chapter 63 „Services. General provisions”, Chapter 82 „Indemnification” and other can also apply to the relations which arising in the sphere of IT.

Among other legislative acts that are applied in the IT sphere, it should be noted The Law of Ukraine „On Copyright and Related Rights"; The Law of Ukraine „On the Protection of Rights to Inventions and Utility Models”; The Law of Ukraine "On the Protection of Rights in Trademarks and Service Marks”; The Law of Ukraine „On Protection of Rights to Industrial Designs"; The Law of Ukraine "On the Protection of Rights to Topographies of Integrated Circuits"; The Law of Ukraine „On Television and Radio Broadcasting" and others.

The secondary legislative acts in IT sphere regulation are, in particular, Resolution of the Cabinet of Ministers of Ukraine of 11 April 2012 No. 295 „On Approval of the Rules of provision and receipt of Telecommunication Services"; Resolution of the Cabinet of Ministers of Ukraine of 04 March 2004 No. 253 "On approval of the legalization of computer programs in the executive branch"; Directive of Cabinet of Ministers of Ukraine of 10 September 2003 No. 1433 „On approval of the Procedure of use computer in the executive branch"; Directive of Cabinet of Ministers of Ukraine of 15 May 2002 No. 247-p „On Approval of the Concept software legalization and control of illegal use of it" and others.

2. International treaties as the sources of law are of great importance for the regulation of information technology relations.

In accordance with Art. 9 of the Constitution of Ukraine, international treaties that are in force, agreed to be binding by the Verkhovna Rada of Ukraine, are part of the national legislation of Ukraine.

Among such international treaties can be called the European Convention on Transfrontier Television, ratified with a reservation contained in the law of December 17, 2008; Association Agreement between the European Union and its Member States, of the one part, and Ukraine, of the other part (provisionally apply in part of exclusive and shared competences of the EU) etc.

It should be noted that the extraterritorial nature of the construction and operation of the Internet network predetermines the need for a combination of international and national legal regulation. Currently, international legal regulation of relations on the Internet is implemented 
through the norms of so-called "Soft law" in the form of various recommendations, resolutions, and declarations issued by international organizations (International Telecommunication Union, World Intellectual Property Organization, UN, UNESCO, Council of Europe, Internet Corporation for Assignment of Names and Numbers, etc.).

In particular, these documents are The Recommendation concerning the Promotion and Use of Multilingualism and Universal Access to Cyberspace adopted by the General Conference of UNESCO at its 32nd session; Declaration on freedom of communication on the Internet adopted by the Committee of Ministers on 28 May 2003; The United Nations Millennium Declaration approved by General Assembly resolution 55/2 on 08 September 2000; Declaration of Principles: Building the Information Society: A Global Challenge in the New Millennium adopted by The United Nations on 12 December 2003 and other.

The provisions of such documents are not binding; their observance by the States is based solely on the authority of organizations which adopt them. Though the norms of "Soft law" do not contain specific liabilities for participants in international relations, but have an influence on legislative process at the national level. At the same time, there is a need to adopt an international treaty that would resolve the issues of the concept of the Internet, its legal regime, structure, applicable law, dispute settlement, and other aspects of the functioning of the network at the national, regional and global levels. Certainly, such regulation of the Internet and the relations that arise in it must take into account the principles of decentralization and selfregulation as the basis for the functioning of the network.

3. To the sources of IT-law, in our opinion, should also include a civil law contract. As already noted, the most of the information technology relations are civil in their legal nature. Taking into account that the legal regulation of the IT sphere today is rather fragmentary and is implemented by adapting the existing legal constructions and norms to IT relations that are more progressive and advanced in their content and nature, it should be noted that it is the standard forms of a civil contract can take into account the peculiarities of this sphere and allows to overcome existing gaps in legislative regulation. Opportunities for this are fixed in Art. 6 of the Civil Code of Ukraine, according to which the parties shall be entitled to enter into an agreement that are not provided by the civil legislation acts but complying with the general foundations of the civil legislation (so called „innominate contracts"). In addition, it is provided that the parties shall be entitled conclude one of the contracts provided by the civil legislation (so called "nominate contracts"), but regulate their relations in it which are not 
regulated by the civil legislation acts or they may deviate from the provisions of civil legislation acts and regulate their relations at their own discretion. But the parties may not deviate from the provisions of civil legislation acts, namely: 1) if this expressly specified in these acts; 2 ) if the mandatory nature of the provisions of the civil legislation acts results from their subject matter or the substance of relations between the parties. It should be noted that the thoughts of the need to include the civil law contract to the sources of law have already been expressed in the scientific literature ${ }^{8}$.

4. Among the sources of IT law should be also noted customary law. In accordance with Art. 7 of the Civil Code of Ukraine civil relations may be regulated by the legal practice, in particular, the business-dealing practice. Customary law is rules of conduct not established by acts of civil law but applied to a certain sphere of civil relations. Custom in law may be specified in the appropriate document or not. The condition for the application of the custom is the absence of contradictions between it and the agreement or civil legislation acts, otherwise such practice shall be not applied to the civil relations.

Customary law can indirectly be expressed in norms, rules, orders, but their true understanding presupposes, first of all, the existence of an idea of the corresponding practice. Their role in the regulation of information relations increases in case when the legislator has not defined the legal regulation of these relations, but they exist and require a certain order and the possibility of functioning?

5. The source of IT law also needs to recognize a judicial precedent. Concerning the expedient and existence of preconditions for the recognition of judicial precedent and judicial practice as a source of law in Ukraine is still a point at issue. At the same time, there are certain grounds for determining the judicial practice as one of the sources of law in Ukraine. So, we should agree that the judicial practice which was formed along with the positive law (legislation) also acquires an obligatory meaning, taking into account: 1) Article 17 of the Law of Ukraine „On Implementing Decisions, and Application of the Practice of European Court of Human Rights", 2) Article360-7of The Civil Procedure Code of Ukraine, Article 11128 of the Economic Procedure Code of Ukraine, Article 244-2 of the Code of Administrative Legal Proceedings of Ukraine, Article458 of the Criminal

8 Довгерт А. С. Джерела цивільного права України: види та співвідношення / А. С. Довгерт // Приватне право і підприємництво. - 2015. - Вип. 14. - С. 12-17; Прилуцький Р. Б. Договір та звичай як джерела господарського і цивільного права України / Р. Б. Прилуцький // Часопис Академії адвокатури України. - 2012. - № 17. - С. 1-9.

9 Селезньова О. М. Джерела інформаційного права / О. М. Селезньова // Правова інформатика. - 2014. - № 3. - С. 53. 
Procedure Code, from which follows the binding of the decisions of the Supreme Court regarding the interpretation and application of substantive law, the unequal application of which became the grounds for the review of the case by the Supreme Court; 3) the position formulated by the European Court of Human Rights that "the law is in force taking into account the practice of its interpretation by competent courts" (Case of Leyla Sahin v. Turkey). The latter concerns both the established practice of the courts in specific cases and the explanations of the higher courts, in which the established practice is expressed ${ }^{10}$.

In our opinion, the formation of a stable judicial practice and its recognition as a source of law are called upon to overcome the existing gaps in legislative regulation, especially in the IT sphere, which seems to be always ahead of the legislative process in terms of its development intensity.

10 Новітнє вчення про тлумачення правових актів : навч. посіб. з курсу тлумачення правових актів для суддів, що проходять підвищення кваліфікації, і кандидатів на посади суддів, що проходять спеціальну підготовку / В. Г. Ротань, І. Л. Самсін, А. Г. Ярема та ін. ; відп. Ред.. В. Г. Ротань. - Х. : Право, 2013. - С. 61. 


\section{THE GAPS IN LEGAL REGULATION IN IT-AREA AND ITS OVERCOMING}

The acceleration and development of scientific and technological progress, information technologies, computer equipment and computer networks in Ukraine is based on the introduction of flexible automated systems, microprocessor means and devices for program control, robots and processing centers, has set the most important task for modern science - to educate and prepare the growing generation of scientists and lawyers, who are able to engage actively in a new stage in the development of modern society, which is connected with informatization. In this area, the law is not able to implement rapidly the rules and can not react to sudden changes in the development of public relations. This is normal phenomenon, not only for Ukraine but also for other European countries, even the most stable. Of course, the settlement these social relations will be reflected in the law over the time.

The activities of IT-companies have an affect on relations in Ukraine. Many IT-companies are established by non-resident or have some contracts with foreign companies. Therefore, the innovative methods and modern global HR model and control of the capacity of different companies are implemented to manage these IT-companies. However, IT-professionals have an impact on social relations, their terminology and philosophy, life style, which usually differs from the average, and especially relations with foreign customers and founders, who are their legal standards as well as their law - IT-Law in Ukrainian reality.

It is worth to mention that IT-law is considered from the position of „conceptual approach”, which is defined as a set of ideas, knowledges, associations and emotions that arise from using the term "IT-law", which is also accompany and characterize it. However, not referring to the issue of determining the location of IT-law in the legal system, it should be noted that it is, above all, absolutely normal relations, which are directly regulated by economic, labor, administrative, criminal and civil law. In this section the subsidiary (additional) application of civil law to IT-relationships will be discussed precisely. These relations are also governed by other legislation.

The research of the gaps in the legislation has a long historical tradition that dates back to the works of jurists and philosophers of ancient Greece and ancient Rome, which first have turned their attention to the fact that the law can not fully grasp what is happening. In Roman law, which gave rise to the entire Western European legal tradition, the gaps had been 
recognized objectively. Due to the works of Roman jurists and philosophers, which became the classical heritage, a significant contribution was made in the formulation and solution of problems of overcoming different gaps in law. It is appropriate to note, that the same problem, as well as ways to solve it, at least, depend on the type of thinking that is determined by social, economic and legal factors.

Today the main means to overcome the gaps in IT-law is the elimination and its overcoming ${ }^{1}$. The elimination occurs through legislative work of legislature by making changes and amendments to the legislation, by the publication of new law and improved legal acts. And overcoming is in the process enforcement activity by analogy (from the greek. analogia - matching, similarity) and subsidiary application of the law (from lat. subsidium - additional, standby).

As for the concepts of "legal gaps" and „legislative gap” - they are different, such as a "civil law" and "civil legislation" or "family law” and "family legislation", the contents of which are not identical.

The analogy is a logical reception, which is guided by the laws of logic. The logical term „analogy”, which means the relationship of partial similarity in features, proportions, elements between two or more subjects, their groups, events etc. The analogy has similarities, correspondence between events, objects, concepts. In IT-law analogy applies in cases where there are relations which is not regulated by the basic law or by-law. In this case, the law or by-law, that regulates such kind of relations, can be applied.

The analogy - is solving the case or separate legal issues through the law that regulates similar relations. Under analogy understand settlement of the case or certain legal issues with help of general principles of law. When we use analogy, under general principles of law means the legal and general principles of law sector. Thus the principles should be fixing in IT law.

Conditions of application of analogy of law and analogy of rights in IT-relationship provided by civil law. According to ch. 1, Art. 8 CC of Ukraine used the analogy of the law in cases where relations are subject to civil regulation are not regulated by the CC of Ukraine, other acts of civil law or contract, they are governed by the legal regulations of the CC of Ukraine, other acts of civil law governing similar to content civilian relations. According ch. 2, Art. 8 of the CC Ukraine failing to use the analogy of the law for the regulation of civil relations, they are governed by the general principles of civil law. Using of analogy of law should be based not only on general principles and sense of civil law, but also „requirements of good

Скакун О.Ф. Теорія права і держави. 4-те видання. Підручник. - К. : Алерта, 2016. - C. 428 
faith, reasonableness and fairness." Thus, first used the analogy of the law, and if you can not use it - an analogy of rights. The analogy of rights is allowed when there is the presence of gaps in the legislation, which cannot be removed by using the analogy of the law.

Gaps in IT law can be eliminated by using analogy of the law only by the court. Any body or a person who has civil jurisdiction (applies IT- rules) can use the analogy of law: all levels of courts, prosecutors, notaries etc ${ }^{2}$.

There are such relations in IT-law, for example, the relations arising from contracts of certain contractual type: as part of the contract such as buying and selling - an analogy (analogy of law) is possible in relations, which arising from IT-contracts retail sale, supply, mines, etc.; under the property law, it is possible to use the analogy between individual property law.

The Civil Code of Ukraine also contains an article 220, which establishes the following: if the parties have agreed on all essential terms of the contract, which can be proved by written evidence, and there was a full or partial performance of the contract, but one of the parties avoided him notarization, the court can recognize a valid contract. The similarities of relations on notarization IT-agreement appears in the subject composition (person signed sales contract), the object act - making the transaction. The similarity of legal content appears in the buyer's rights for require the license agreement and the seller's obligation to do action. It is also necessary to bring art. 1162 Civil Code of Ukraine, which contains no direct reference or referential rules about how much and in what order damage, caused by salvage another person's property have to be reimbursed. Resolving these issues is possible through the use of a analogy order of the law rules of Chapter 82 Civil Code of Ukraine dedicated to the obligations arising from the injury offense (tort liability). Chapter 82 has a universal character and applies to all cases of compensation for the damage.

Given the role of civil law as „mother branch” and related relationships to which it applies, subsidiary application of civil law to IT-relationship is possible. Art. 9 CC of Ukraine determined the admissibility subsidiary application of the provisions of Civil Code of Ukraine to the related relations, if they are not regulated by other laws. Under the subsidiary application of the rules of civil law needs to understand the legal mechanism that allows dumping legislation irrational duplication of identical or similar rules and concepts related to relationships, institutions, areas of law. Specified way to overcome gaps related to the additional procedures for the complete elimination of gaps do not occur.

2 Харитонов Є.О., Харитонова О.І., Старцев О.В. Цивільне право України: Підручник. Вид. 3, перероб. і доп. - К. : Істина, 2013. - 808 с. (С. 88) 
Therefore, the subsidiary application of civil law is a result of conscious avoiding duplication legislator existing norms in civil law to be applied to adjacent relationship in the IT-law and active use of other substantive and procedural areas of the law. In other words, the need for re-regulation of these relations and consolidation the material and procedural law norms no longer relevant.

The civil law of Ukraine is delimited subsidiary application of civil law by analogy law (intersectoral analogy).

Firstly, subsidiary application of civil law in some cases may be not temporary, as a kind of analogy of law (interdisciplinary analogy), but stable, directly by the legislator in order to achieve unity of legal regulation of social relations, as occurs in the regulation of IT relationship.

Secondly, the use of subsidiary legislation made directly by the will of the legislator that the relevant legal norm introduces special reference to the other rules that govern these relationships.

Thirdly, the basis for regulatory action analogy of law in civil law of Ukraine is art. 8 CC Ukraine and ground subsidiary application of of civil legislation - art. 9 CC Ukraine.

Fourthly, the subjects use analogy of law (intersectoral analogy) are only courts in resolving disputes in the IT-sphere, the subsidiary application of the law can be made by all parties to the IT-relationship.

It seems more appropriate to treat the application of subsidiary legislation as more broader than only as intersectoral analogy of, because it can be used in the presence of gaps in the law and in their absence (as a means of saving the regulatory material).

However, whether considered subsidiary application of civil legislation or some analogy a kind of legal mechanism that allows to unload regulatory material, it is only possible under certain conditions. Therefore, to ensure the rule of law and legitimacy in regulating any relationship makes it necessary to identify those legal conditions under which the use of legal norms for application of subsidiary legislation to the IT-relationship will be recognized as necessary, feasible and appropriate.

As aptly noted Y.H. Kalmykov, „powerful enforcement agencies do not use the term „subsidiary application of the law," they either directly refer to the need for a particular norm of law related field, or formulated to appeal to the latter in expressions such as „according to Art. ..." 3 .

\footnotetext{
3 Калмыков Ю.Х. Условия субсидиарного применения норм гражданського законодательства к семейным отношениям. / Основы законодательства Союза ССР и союзних республик о браке и семье в правоприменительной практике. - Саратов: Издво Сарат. унта, 1978. - C. 28-32. (C. 28)
} 
In particular, the terms subsidiary application of civil legislation to IT-relationships:

1. IT-relations are unsettled. The lack of standards in the adjacent law governing IT-relationship can not be corrected by using the analogy of the law, the right analogy, the use of judicial practice or business traditions;

2. There are norms that govern these IT-relationship in civil law. Refers to a genetic connection related branches of legislation.

Related areas of law - those that have similar subject matter and methods of regulation. Related branches of civil rights by such branches as: family, business, labor, international private, commercial and procedural, administrative, land, nature resource, finance, etc. ${ }^{4}$.

3. Uniformity of subject and method of legal regulation in related fields of law governing IT-relationship uniform with those for which there is vicarious application of civil law.

4. Lack of direct prohibition on the use of subsidiary legislation. Subsidiary application of of civil legislation to IT-relationship is not prohibited by the legislator.

5. The decision on the basis of and within the law related areas of law in the field of IT-relationship, according to their objectives, principles and common sense. It is important to emphasize that the choice of the applicable subsidiary legislation should be consider the principles inherent in law, which actually belong to these rules. Thus, the use of subsidiary legislation takes place only between the relations in the IT-sphere, which is identical by its nature and are genetically interrelated.

In some cases, another conditions of the subsidiary application of civil legislation is the existence of the entity authorized to such application. Subjects who can use the subsidiary application of of civil legislation these relationships are all members of the IT-relationship.

The result of subsidiary application of of civil legislation to IT-relationship is to take these subjects law enforcement Act - approval or court decisions, statutes and other regulations of public and private businesses and individuals. In any case, the important is compliance with the application of subsidiary legislation these entities, which is excluding the possibility of abuse of this legal mechanism. It is not allowed to adapt similar standards related to relationships in the IT-field through a different interpretation of it, because the subsidiary application of of civil legislation is not interpreting the content of regulation, and the transfer of its impact on IT-content and nature of the relationship.

4 Майданик Р.А. Цивільне право: Загальна частина. / Т.І. Вступ у цивільне право. - К. : Алерта, 2012. - 427с. (С. 189) 
To subsidiary application of civil legislation to IT-relationships meets the requirements of a particular truth, its basis should be based on principles - such starting the idea of his being, expressing the most important laws and the foundations of this type of law is equally with the essence of law and constitute its main features differ versatility, and overall higher imperative importance, meet an objective need to build and strengthen certain social order.

In Art. 3 CC of Ukraine legislator consolidated general principles of civil law, which are: 1) the inadmissibility of arbitrary interference in the private sphere of life; 2) the inadmissibility deprivation of property rights, except as prescribed by the Constitution of Ukraine and the law; 3 ) the freedom of agreement; 4) the freedom of business activity that is not prohibited by law; 5) the judicial protection of civil rights and interests; 6) justice, fairness and reasonableness.

Considering the general legal principles and on the basis of general principles of civil law and application as subsidiary legislation may all parties allocate IT-relationship following principles:

1) the principle of inadmissibility of arbitrary interference in private life;

2) the principle of freedom of contract;

3) the principle of judicial protection of rights and interests;

4) the rule of law, equality, reasonableness;

5) the principle of fairness, integrity, prudence and efficiency.

Because of these legal concepts and designs that are equally interpreted and applied in various industries, institutions of law and relations (statute of limitations in the case of protection of honor, dignity and business reputation, the general provisions of the contract of service, compensation for damage), give some examples subsidiary application rules of civil legislation relations to IT-relatoinship, as can gave us a comprehensive understanding of the mechanism.

- the subsidiary application of civil legislation in family relations in the IT-sphere.

According to part 1 of article. 9 CC of Ukraine, its rules can be used subsidiary for regulation some family relationship, if they have not regulated by other legislation act. The main idea of this article, is that: if there are not any rules in Family Code Of Ukraine, which is regulated IT-relationship, we can use articles of CC of Ukraine.

The CC of Ukraine about the protection of civil rights and interest can also be subsidiary applied to the family relationship in IT-area. In particular, the forms of protection of civil rights and interest in IT-relationship is: judicial protection (Art. 55 Constitution of Ukraine, 
Art. 16 CC of Ukraine); administrative protection (Art. 17 CC of Ukraine); notary protection (Art. 18 CC of Ukraine); self-defence (Art. 55 Constitution of Ukraine, Art. 19 CC of Ukraine).

Considering the current level of social development, it can not be imagine a person who does not take part in the IT-relationship. To ensure full participation of individual natural persons in public relations, the legislator establishes the right to respect for dignity and honor; right to inviolability of goodwill; privacy and confidentiality (Articles 297, 299, 301 CC of Ukraine), whose position vicarious apply to family relationships in the IT field.

Protection of honor, dignity and business reputation in the IT-relationships the right of citizens and legal persons (couple) request a court rebuttal website false information (information that does not correspond to reality, or contained false) that degrades their honor, dignity or business reputation or harm their interests. False information - information that is incorrect or falsely described, that contains information about events and phenomena which do not exist or have existed, but information about them is untrue (partial or distorted). The right to protection of honor, dignity and business reputation in the IT field by the Constitution of Ukraine (part 4 Art. 32), CC of Ukraine (Art. 277). On the issue of procedures for the protection of honor, dignity and business reputation of the Supreme Court could clarify the purpose of ensuring the correct and uniform application by the courts of law governing the protection of honor and dignity of the individual and business reputation of physical and legal entities. In Plenum Supreme Court noted that the defendant in cases where the dissemination of false information on the Internet, is the author and owner of the website. The plaintiff must set itself the author and owner of the web resource for drafting and filing a claim. If it is impossible to find the author or his place of residence (location) of the defendant in the case is the person from whom the property is a website. This means that if the author can not be established - then identified website.

In such cases arising from IT-relationship in accordance with paragraph 2 of Part 2 of Art. 258 CC of of Ukraine, the statute of limitations is special and is 1 year (in this case, the statute of limitations is calculated from the date of placement of this information on the website or from the date when the person learned or could learn about this information).

At the same time with the requirements of the protection of honor, dignity and business reputation of the couple, their parents and children can also claim compensation for moral damages in the event of family relationships under Art. 1167 CC of Ukraine. In this case, the obligation to prove that the damage was caused moral relies on the plaintiffs. They are also obliged to determine the amount of moral damages, but ultimately the 
amount of monetary compensation for moral damages determined by the court depending on the nature of the offense, the depth physical and mental suffering, deterioration of skills the victim or deprivation of their feasibility, the degree of guilt of the person who caused moral damage if guilt is the basis for compensation, as well as the other circumstances which are essential. In determining the amount of compensation takes into account the requirements of reasonableness and fairness.

It is also necessary to note that the civil law is regulated reparation obligations, the provisions which apply to vicarious family relationships in the IT-area. The right to compensation in such cases arises when held up information from another website owned by spouses or assigning IT-discovery, IT-invention and ect. Particularly, property damage caused unlawful decisions, actions or omissions of the moral rights of the natural or legal persons as well as damage caused to the property of a person or entity shall be compensated in full by the person who caused (Art. 1166 CC of Ukraine).

Considering the large amount of CC of Book 6 Ukraine „Inheritance Law” in the general chapter. 84 CC of Ukraine „Terms of succession”, except Articles 1227-1232-1, Ch. 85 CC of Ukraine „Inheritance under the will”, Ch. 86 CC of Ukraine „Inheritance by the law", Ch. 87 CC of Ukraine „The right to inherit," Ch. 88 CC of Ukraine „Implementation of the covenant," Ch. 89 CC of Ukraine „registration rights to inheritance," Ch. 90 CC of Ukraine „Hereditary contract” vicarious be applied to family relationships in the IT-area.

- the subsidiary application of civil law to labor relations in the IT-area.

The use of civil law to labor relations permitted by law, in accordance with part 1 of art. 9 CC of Ukraine its terms apply to the settlement labor relations if they are not regulated by other laws.

In particular, one of the institutions, which is traditionally exist in the CC of Ukraine, but is absent in labor laws in the IT-area, is a set of legal norms about personality. The essence of the category of „personality” had been studied in the science of labor law and in the science of civil law successfully. In civil law legal individual has civil capacity in rights and civil capacity in action.

The first element of personality - capacity in rights. Legislative well known that the person has capacity in rights is occurs from birth. Whether or not a person wants, she can not waive their legal capacity, voluntarily alienats it in any other way to get rid of. A person has the capacity in rights, this person is subject to the law, because of the fact that the law, as a general social phenomenon, exists independently of any external factors.

The second element is the legal capacity in action. In general, the legal capacity in action refers to the ability of individuals to take their actions 
for themselves the rights and bear the responsibilities. Disability - a loss of the ability to exercise rights and obligations as a result of severe mental disorders. The criteria for disability by civil law is mentally ill. According to Art. 39 CC of Ukraine the grounds of recognizing a person is disability - a chronic, persistent mental disorder that results in the inability person aware of the importance of their actions and (or) control them.

Paragraph 1 of Part 1 of Article 32 of the CC of Ukraine recognizes minors from 14 to 18 years the right to dispose of his earnings, scholarships or other income. Thus, the CC of Ukraine considers that despite the incomplete civil capacity, a person can participate in employment in the IT-area, thus this person already has her IT-capacity. Moreover, the availability of labor IT-capacity at person under 16 years provides an opportunity to purchase the full civil capacity in the order of emancipation: Art. 35 CC of Ukraine admits this possibility if the minor works under an employment contract.

Thus, CC of Ukraine, on the one hand, allows civil legal subsidiary impact on labor relations in the IT field, and the other - limits its regulation of the sector civil capacity.

It seems that the rules of civil law on legal capacity in rights and capacity in action subsidiary can be applied to labor relations in the IT-area. They can be applied and are important rules Articles 36, 40 CC of Ukraine that the individual is recognized incapable and incompetent since the entry into force of this court.

The design „compensation of lost profits” ( „compensation for lost profits") fully applies to labor relations. According to Art. 22 CC of Ukraine, lost profits - is income that a person could really get under normal circumstances, if his right was not violated. Thus, the subsidiary applicable rules of civil law for compensation of lost profits to the relations arising between subjects IT-relationship is acceptable.

- The subsidiary application of civil law to the economic relations in the IT field.

Let's start with the fact that the economic relations the norms CC of Ukraine and other acts of civil law in the part which is not defined peculiarities of legal regulation of these relations norms Civil Code of Ukraine. This mechanism is regulated by the legislator in paragraph 2 of Articles 9 CC of Ukraine, which states that the CC of Ukraine may provide features regulation of property relations in economic sphere.

Most IT-companies, IT-professionals as business entities operating in the form of Individual and business partnerships.

Individual operates in accordance with Chapter 5 CC of of Ukraine "individual entrepreneur", there is thus subsidiary rules applicable to the 
civil law of economic relations in the IT-area. Particularly, part 1 of art. 50 CC of Ukraine provides for the right individual with full civil capacity of establishment which is prohibited by law.

Also, according to paragraph 1 of Part 2 of Art. 55 CC Ukraine relations to create business organizations are legal entities and subsidiary regulations apply Ch. 7 CC of Ukraine, and according to relations on the order creation and order of individual types of business partnerships subsidiary, the rules $\mathrm{Ch} .8$ CC of Ukraine (Art. 92 of the Civil Code of Ukraine). A legal entity may conduct its activities in a form of commercial companies: general partnership, limited partnership, limited or additional liability company (ch. 2, Art. 113 CC of Ukraine).

Implementing software is a major focus of many IT-companies in economic relations.

For the distribution of software products often use license, sub-license agreements, supply contracts copies of computer programs, contracts for information services, agency contracts.

Part 6 of article 265 CC Ukraine provides direct subsidiary application of the CC of Ukraine on the sales contract to supply relations are not regulated by the Civil Code of Ukraine. However, it is possible to use only art. 655-697 CC of Ukraine, because according to ch. 2, Art. 712 CC of Ukraine general terms of sale apply to the supply agreement, unless otherwise provided by contract, law or follows from the nature of the relationship of the parties. We emphasize that the provisions of CC of Ukraine for the sale of IT objects used to supply relationships to the extent not inconsistent with the Commercial Code of Ukraine.

Property and economic obligations in the IT-regulatory legal relations are relations of material nature occurring on statutory grounds, in which one party (the debtor) is obliged to act in favor of the other party (the creditor) a certain action (transfer property, to perform work, to provide the service, pay money, etc.) or to refrain from certain action, and the creditor may require the debtor committing these acts while the responsibility of its adoption and confirmation. In this regard, the economic laws down general rules for regulation of commercial property obligations. Therefore, the rules of vicarious Chapter 77 CC of Ukraine with the specifications provided by commercial law.

General rules for contracts prescribed by Articles 638-650 CC of Ukraine, which vicarious used to meet the requirements of Articles 181-187, Articles 264-376 CC Ukraine concerning commercial IT-contracts in general and their individual species in particular.

To IT-contract legally held, the parties must agree on all its essential terms. If such a transaction is no bilateral least one essential condition, all IT-contract is not concluded, it is one that does not take place, and therefore 
it can not generate economic obligations. If one of the parties not concluded the contract shall take actions aimed at its implementation, it can protect its rights by applying the subsidiary provisions of Ch. $83 \mathrm{CC}$ of Ukraine, and in the case of destruction or damage of property - filing a claim for damages.

Under paragraph 2 of Part 1 of Art. 199 of the Commercial Code of Ukraine regarding IT-relations to enforce the obligations of participants economic relations, the rules of vicarious Ch. 49 CC of Ukraine. Particularly, according to the $\mathrm{CC}$ of Ukraine means to enforce the obligations are divided into proprietary (mortgage (Art. 572) delay (p. 594), deposit (Art. 570) and a binding legal (penalty (Art. 549 ) guarantee (Art. 553) guarantee (Art. 560).

By IT-relationship related to use in business intellectual property subsidiary, the rules of civil law, in particular art. 426 CC of Ukraine (ch. 2, Art. 154 of the Civil Code of Ukraine) and IT-relationship in the case of intellectual property rights protection for objects mentioned in ch. 1, Art. 155 CC Ukraine, governed by CC of Ukraine (ch. 2, Art. 155 of the Civil Code of Ukraine). For some powers regarding the use of an invention, utility model and industrial design subsidiary applied art. 464 CC of Ukraine, under Art. 156 of the Civil Code of Ukraine.

IT-relations in innovative activities subsidiary, the rules CC of of Ukraine of research or research and development and technological works (Art. 332 of the Commercial Code of Ukraine).

As is known, the criterion of truth is practice. The practice soon reveals many weaknesses, gaps and other problems. An important consideration is the analysis and enforcement activities of judges and other law enforcement entities, which are used daily vicarious rules of civil law relations to IT-relationship, though they do not understand. This clearly observe their appropriateness and effectiveness. Their use can and should serve as a guideline for the legislator.

The subsidiary application of civil law relations to IT-relations is the reality, as civilian and allied IT-relations is related. The subsidiary application of civil law to IT relationship - a mechanism for efficient, rapid elimination of gaps and cost of regulatory material in adjacent relationship in the IT-area who are under legal pressure and need it legal mediation, by applying the law of civil law for these relationship maintenance to enhance its effectiveness. Analysis subsidiary application to the IT-relationship of the civil law allows for conclusions: 1) the rules of civil law apply to the relations related to the IT-area in the part not regulated by rules of law; 2) rules of civil law which apply to the related subsidiary relationship in the IT-area, only for their informational content are civilians; 3) Subsidiary application of civil law relations related to the IT-area in no way changes the last sectoral affiliation relationships. 


\section{PREVENTION OF UNLAWFUL TRADEMARK USE THROUGH THE INTERNET: BEST EUROPEAN PRACTICES}

As the virtual world increasingly intersects with real life, companies across the EU might be interested in a clearer regulation of keyword advertising. A great number of well-known firms in the UK, France, Germany, Austria, the Netherlands and Belgium are faced with the problem of the sale of keywords, which correspond or are identical to famous trade marks, by Internet service providers (ISPs) to third parties. One of the main reasons behind this trend is the public's growing preference for online shopping, either for products or services. As an Internet user conducts a search based on certain words/phrases, ISPs then produce a list of sites, which best matches those keywords in decreasing order of relevance. As a result, in order to attract more clients, owners of specific websites started buying keywords from the most popular ISPS. This situation led to the point where trade mark proprietors complained about the infringement of their trade mark's rights.

The popularization of the Internet was accompanied by a variety of problems that have to be regulated legally. These, however, are not always foreseen by the legislator in time. It is common for different branches of science to intersect and as a result to create totally new legal formations. For example, the intersection of keyword advertising technologies and EU trade mark law led to the emergence of clearer and more detailed legal regulations.

In order to gain a better understanding of the keywords advertising dispute, one should first analyze the legal background of trade mark use and the main characteristics of using them as keywords in Internet advertising.

In 1990, it was stated for the first time by the European Court of Justice in relation to HAG II (Case C-10/89) that 'the system of undistorted competition requires that companies are able to create and maintain relations with their customers by virtue of the quality of their goods.' First and foremost, distinctive signs are essential for allowing customers to recognize goods, while they also provide an opportunity to set up a connection between goods/services and the enterprise responsible for their marketing and quality. The second most significant ruling was that 'trade marks must guarantee the identity of origin of goods bearing them.'

\footnotetext{
1 Max Planck Institute for Intellectual Property and Competition Law. Study on the Overall Functioning of the European Trade Mark Law System (European Commission). - 2011. - P. 50. Режим доступу: http://ec.europa.eu/internal_market/indprop/tm/index_en.htm.

2 ibid.
} 
As it was defined by Murray, 'branding is a watchword of marketers.'3 Trade mark protection must guarantee that all products were produced and launched on the market under the supervision of a singular enterprise. This is a fundamental principle for the explanation of the idea of "trade mark use" and „use of a sign for goods" according to Art. 5 (1) (a) Trade Mark Directive (TMD) and Art. 9 (1) of Community Trade Mark Regulation (CTMR).

The legal justification of the principle of undistorted competition is based on the case law created by the European Court of Justice (ECJ). Nonetheless, there is no case law interpreting the use of trade marks ,in the course of trade” or, "trade mark use." It is necessary, however, to keep in mind that a distinction should be made between "trade mark use" and other forms of use. By contrast, there are number of ECJ decisions dealing with the concept of a sign used "as a trade mark."

Art. 5 (1) (a) of TDM determines that trade mark proprietors are able to prevent third parties without their consent, from „using in the course of trade any sign which is identical with the trade mark in relation to goods or services which are identical with those for which the trade mark is registered."

As correctly noted by Waelde, ' $80 \%$ of Internet users, who are searching for a specific site, will start their search using a search engine', rendering 'meaningful use of the Internet without search engines [... therefore virtually impossible.'5

The main case law is the joint cases of Google France Sarl v Louis Vuitton Malletier $S A^{6}$ as it resulted in a crucial keyword advertising decision. Prior to this case, European national courts did not have a uniform policy as to the liability of ISPs and keyword advertisers. As a consequence, ECJ made a clear and coherent statement in Google France, where the ad text in fact included the brand's name (Louis Vuitton); the other two cases by comparison did not. The facts of the case are based on the regulations of the First Council Directive 89/104/EC which was replaced by Directive 2008/95/EC with no alterations to be made in the provisions that are examined in the present

3 Murray A. Information Technology Law: Monograph. / A. Murray. - Oxford: Oxford University Press, 2010. - 289 p.

4 See, e.g., (C-63/97) Bayerische Motorenwerke AG v Deenik [1999] E.C.R. I-905, paras 34-38; (C-2/00) Holterhoff $v$ Freiesleben [2002] E.C.R. I-4187, para 17; (C-228/03) Gillette Co v LA-Laboratories Ltd Oy [2005] ECR I-2337, para 28.

5 Bednarz T., Waelde C. Search Engines, Keyword Advertising and Trade Marks: Fair Innovation of Free Riding? in Edwards L., Waelde C. Law and the Internet. / L. Edwards, C. Waelde. - [Third Edition]. - London: Hart Publishing, 2009. - P. 227.

6 (C 236/08 - C 238/08) Google France Sarl v Louis Vuitton Malletier SA [2011] ECR I-2417. 
paper. Therefore, there is an ambiguity revolving around issues of using trade marks as keywords in advertising that creates the impression that it will remain a forever unsolvable problem.

The ECJ has referred a number of questions to the national courts of Member States and, as a consequence, opened the way for a multiplicity of interpretations regarding the new claims national courts had to examine. While it was generally agreed that the judgment was in favour of Google, it is reasonable to assume that the outcome of new cases will depend upon the ability of solicitors to present the case from their side.

It might be a surprising fact that only one out of three users distinguishes between an advertisement and a search result. One in six recognizes a sharp difference and one in ten acknowledges that there is a financial link between the advertisements and the search engine. ${ }^{7}$ When composite advertisements are screened it is likely to be difficult for a user to understand what the real link to the trade mark owner is.

Significantly, the ECJ's case law has decided only on cases where the trade mark owner had priority in the displayed results. The evidence suggests that only a small amount of users pays attention to the search results located on the right side of the screen. Consequently, only the top two positions can guarantee visibility, otherwise there is the probability that the website will be passed over.

In German legal practice the court assumes that users will realize the link between keyword advertisers and ISPs as a matter of course, while, by comparison, according to French practice this assumption was disproved. In fact, the ECJ gave the opportunity to national courts to decide for themselves in this matter.

The ECJ regards the notion of eminent and reputable marks as associated „kindred concepts." ${ }^{8}$ Well-known marks have to correspond primarily to the provisions of Art. 4 (4) (a), 5 (2) TDM and Art. 8 (5), 9(1) (c) CTMR. It is worth underlying that trade marks, which fulfil the reputation requirements of Member States, are instantaneously acknowledged as well-known in accordance to Art. $6^{\text {bis }}$ of the Paris Convention. ${ }^{9}$

7 Ott S., Schubert M. It's the Ad Text, Stupid: Cryptic Answers Won't Establish Legal Certainty for Online Advertisers / S. Ott, M. Schubert // Journal of Intellectual Property Law \& Practice. 2011. - No 6 (1). - P. 3.

8 Max Planck Institute for Intellectual Property and Competition Law. Study on the Overall Functioning of the European Trade Mark Law System (European Commission). - 2011. - P. 50 [Електронний ресурс]. - Режим доступу: http://ec.europa.eu/internal_market/indprop/tm/ index_en.htm.

9 Paris Convention for the Protection of Industrial Property 1883 [Електронний ресурс]. Режим доступу: http://www.wipo.int/treaties/en/ip/paris/trtdocs_wo020.html. 
Misleading advertising can have a negative influence on the consumer's economic welfare. The author agrees with Seville that the omission of a wellknown trademark might be misleading, if the brand was a very important element in the buyer's decision. ${ }^{10}$

The bulk of examined cases on the problems in question deals with Google as the ISP. For this reason and for the fact that this company is currently the leader in innovative enterprises, when the present paper refers to ISP, it will usually denote Google.

Keyword advertising services „AdWords” and „AdSense,” owned by Google, are the main sources of advertising income for the company. Every day the ISP receives a huge amount of revenue from the aforementioned services.

Google also owns two distinct Keyword Tools: Google AdWords and Search-Based Keywords Tool. The first one is accessible only for AdWords clients; the second is open to the public and can propose a certain combination of words that may help to get the highest ranking position in the search list. Moreover, search outcomes using this software are likely to be slightly different because of the different algorithmic formulas used in each programme. It might be worth mentioning that AdWords was also available for everyone to use before it was substituted by the SearchBased Keywords Tool.

According to the author's opinion it is essential for the reader to understand the mechanism behind the keyword advertising service.

While typing a word in the search engine two types of results appear, called „natural” and „sponsored” results. Natural results are the list of Internet sites corresponded to those words and are selected objectively. Sponsored results are keywords which Google allows entrepreneurs to buy and they are selected by invisible keyword advertising technologies. 'The sponsored link, typically accompanied by a short commercial message, appeared on the screen beside or above the natural results.'1" The same keyword might be selected by several advertisers.

Keywords are usually sold in auction, where the price of a bidden keyword increases if several advertisers want to buy the same one. The price can also depend on whether this particular keyword was in high-usage in the past.

The intersection of law might occur when advertisements on the Internet display signs identical to trade marks.

It was questioned by an Austrian court 'whether an infringement depends upon if an ad is shown in a separate section and is labelled as

10 Seville C. EU Intellectual Property Law and Policy: monograph / C. Seville. - Chentelham: Edward Elgar Publishing Limited, 2010. - P. 284.

11 (C 236/08 - C 238/08) Google France Sarl v Louis Vuitton Malletier SA [2011] ECRI-2417. 
an advertisement.'12 The ECJ denied a response to this query as it was not pertinent to any case in particular. As can be seen, the only visible chance to receive an explanation from the $\mathrm{ECJ}$ on how it is possible to detach the essential function of keyword advertisements from the requirement to isolate them from their context failed.

It should be highlighted that keyword advertising through „AdWords” has a restriction of no more than 95 characters. Because of this there is no certainty that keyword advertisers will have enough space to discredit any possible links with trade mark proprietors. Ad Words is composed of four lines: the title line has space for 25 characters, and the rest have 35 symbols each with the Display-URL on the last line. Top advertisements, however, have only 2 lines with the same allowance. Furthermore, these are not the only constraints keyword advertisers are faced with. There is a mandatory requirement in the inclusion of the price and additional promotional information. 'The Display-URL shown at the bottom of the ad has also to fulfil certain criteria. It needs not to be identical to the Destination-URL to which the ad is linked, but it has to be a genuine URL that is part of the advertiser's site. ${ }^{13}$

In 2004 Google allowed its clients in the US and Canada to bid for keywords corresponding to brands. On May $5^{\text {th }} 2008$ the ISP decided to expand the same policy in the UK and Ireland. Prior to that date it was not permitted in the UK to buy keywords that were identical to brands. Since that time the ISP has created an Advertising Legal Support Team where the potential advertisers could check whether the desirable keyword was similar to that of a registered brand. As a result, advertisers that are 'normally informed and attentive' ${ }^{1 / 4}$ Internet users should know before bidding if their keyword is "free" from a trade mark. The only exceptions to this rule are pharmaceutical keywords and Facebook.

It is worth mentioning that Internet users do not pay when they use keyword links. Keyword advertisers, on the other hand, have to pay the ISP every time a user clicks on the sponsored link.

One of the main problems of keyword advertising is a claim raised by trade mark proprietors that this type of Internet services leads to misleading advertising, consumer confusion, unfair competition and infringement of their rights.

12 (C-278/08) Die BergSpechte Outdoor Reisen und Alpinschule Edi Koblmuller GmbH v Guni [2010] E.C.R. I-2517.

13 Ad Words Help, Destination-URL, https://adwords.google.com/support/aw/bin/answer. py?hl=en-ukcthlrm=dectanswer $=6314$

14 (C 236/08 - C 238/08) Google France Sarl v Louis Vuitton Malletier SA [2011] ECRI-2417, para 84. 
As mentioned in the Preamble of Directive 2006/114/EC 'misleading and unlawful comparative advertising can lead to distortion of competition within the internal market. ${ }^{15}$ Differences in the advertising legislation of Member States 'have direct effect on the smooth functioning of the internal market ${ }^{16}$ and can cause negative influences on the free circulation of goods and services, as well as deceive businesses around the EU. That is why a comparative analysis of keyword advertising liability in different Member States should be conducted, since the extant differences in legislation might be the root of the problem.

The author agrees with Tobias Bernarz and Charlotte Waelde that consumer confusion is 'the touchstone of liability ${ }^{17}$ and also one of the reasons why the problem in question has arisen. It is essential for trade mark proprietors to protect their trade marks from improper advertisement and the possible confusion of clients.

UK is the country with the least number of cases concerning keyword advertising disputes (the policy put in place in May 2008 seems to be favourable to ISPs). The leaders in this area are France and Germany, where the majority of EU decisions on the subject were taken.

The author of the present paper is largely in agreement with Seville ${ }^{18}$ that the E-Commerce Directive (ECD) has the strongest impact on ISPS liability. In particular Art. 12-14 stipulates liability exemptions and Art. 15 deals with the monitoring of obligations. In the most recent decisions, the Supreme Courts of Member States adopted the ECJ's decision in Google France ${ }^{19}$ applying the limited liability rules established by ECD. As a consequence, it is likely that ISPs will 'enjoy limited liability if their activities are neutral, or passive, in respect of the infringement at stake. ${ }^{20}$ Following from Seville's point of view, there is a general argument that ISPs are immune from liability, i.e. they are not liable for the content of the information they transmit, because they act as a 'mere conduit.'21

15 Directive 2006/114/ EC.

16 ibid.

17 Bednarz T., Waelde C. Search Engines, Keyword Advertising and Trade Marks: Fair Innovation of Free Riding? in Edwards L., Waelde C. Law and the Internet. / L. Edwards, C. Waelde. - [Third Edition]. - London: Hart Publishing, 2009. - P. 271.

18 Seville C. EU Intellectual Property Law and Policy: monograph. / C. Seville. - Chentelham: Edward Elgar Publishing Limited, 2010. - P. 47 - 49.

19 (C 236/08 - C 238/08) Google France Sarl v Louis Vuitton Malletier SA [2011] ECRI-2417.

20 Matulionyte R., Nerisson S. The French Route to an ISP Safe Harbor, Compared to German and US Ways / R. Matulionyte, S. Nerrison // International Review of Intellectual Property and Competition Law. - 2011. - No 42 (1). - P. 66.

21 Seville C. EU Intellectual Property Law and Policy: monograph. / C. Seville. - Chentelham: Edward Elgar Publishing Limited, 2010. - P. 48. 
Additionally, they cannot be held liable for the storage of information at the request of the advertiser, unless they know about the unlawful character of that information or the advertiser's activity and do nothing to prevent its dissemination. It is worth underlying that ISPS have 'more practical power than right holders to address the infringement of intellectual property rights in material found on sites which they control.'22 While conducting their business ISPs have no obligation to monitor the dispatched information or to investigate illegal actions, as their service is of a 'mere technical, automatic and passive nature. ${ }^{23}$ Conversely, they have to inform the authorities about any wrongdoings that they discover, made by the recipients of their service. As a result, by assisting in the creation of the ad copy for keyword advertisers, ISPS have hidden for a safe harbour and have largely escaped liability.

In spite of the content of Art. 12-14 ECD, courts can still order ISPs to 'terminate or prevent an infringement. ${ }^{24}$

In brief, as follows from the Google France ${ }^{25}$ ruling, an ISP, who conserves symbols/phrases of registered brands as keywords and displays them upon request, does not use that symbol/phrase in compliance with Art. 5 (1)(a) TMD. It is essential, however, to differentiate between trade marks owners within the keyword advertisement copy.

As can be seen from the ECJ judgement, the Court preferred to answer only questions put forward by La Cour de Cassation. It is for this reason that no comprehensive solution on keyword advertising legality in the EU has been found. The most important aspect of this judgement was that all three issues were decided in favour of the ISP. Hence, they are held not liable for the use of brands' signs by third parties. A parallel decision was made in July 2010 regarding the Portakabin v Primakabin case. ${ }^{26}$

Prior to the aforementioned decisions, the national courts of Member States adopted diverse approaches and rulings on the cases of keywords use by third parties. Nevertheless, at present, national courts still have an opportunity, left open by the ECJ, to reconsider the liability of ISPS.

22 Seville C. EU Intellectual Property Law and Policy: monograph. / C. Seville. - Chentelham: Edward Elgar Publishing Limited, 2010. - P. 48. para 113.

23 (C 236/08 - C 238/08) Google France Sarl v Louis Vuitton Malletier SA [2011] ECRI-2417.

${ }^{24}$ McMahon B. Imposing an Obligation to Monitor on Information Society Service Providers / B. McMahon // Computer and Telecommunications Law Review. - 2011. - No 17(4). - P. 93; see also cases (I ZR 35/04) Internet Auction II [2007] ETMR 70 and (I ZR 304/01) Internet Auctions of Counterfeit Watches, Re [2006] ECC 9. para 113

25 (C 236/08 - C 238/08) Google France Sarl v Louis Vuitton Malletier SA [2011] ECRI-2417,

26 (C-558/08) Portakabin Ltd v Primakabin BV [2010] ETMR 52. 
Under the French judicial practice courts of jurisdiction may not adhere to upper courts' judgement. As a consequence, under the influence of the ECJ's decisions, Google decided to change its policy for AdWords.

Under the UK Trade Marks Act 1938 (repealed 31 October 1994) there was a general view that a descriptive use of a trade mark could exist, which would not infringe the trade mark proprietor's rights. Additionally, English courts tend to adhere to the view that using a trade mark sign in keyword advertising does not imply its 'use in the course of trade' and, thus, there is no trade mark infringement. In 2008, UK courts were given their first opportunity to adjudicate on a keywords advertising case in Wilson $v$ Yahoo!, ${ }^{27}$ where the French approach was imitated.

Nowadays, there are limited liability rules, or as they are called „safe harbours" regulating an ISP's liability, which are implemented both in the EU and the US. A lot of grey areas, nevertheless, persist.

As McMahon affirms, a number of cases were referred recently to the ECJ regarding the monitoring responsibilities of ISPs under Art. 267 TFEU. ${ }^{28}$ In the UK case L'Oreal $v$ eBay, ${ }^{29}$ where the Internet auction operator booked the 'L'Oreal' keyword and used it on its website for advertisements of third parties, the trade mark proprietor sought to impose an injunction under Art. 11 of Directive 2004/48/EC ${ }^{30}$ to protect itself from possible future infringements. On 9 December 2010, the Advocate General commented that infringement under Art. 14 of ECD denoted 'past or present infringements but not from the future ${ }^{31}$.

In the legal practice of Germany, keyword advertisers are predominately the defendant. The author of this paper disagree with the point of view put forward by Bednarz and Waelde that even if the ISP was the respondent, there would be no case where they would be found liable. ${ }^{32}$ These scholars offer several explanations for this. It is commonly believed that the ISP, and

27 Wilson v Yahoo! UK Ltd [2008] EWHC 361 (Ch).

28 McMahon B. Imposing an Obligation to Monitor on Information Society Service Providers / B. McMahon // Computer and Telecommunications Law Review. - 2011. - No 17(4). - P. 93 - 96; Treaty on the Functioning of the European Union 01.12.2009 [Електронний ресурс]. - Режим доступу: http://www.vilp.de/localization?id =1458clang=de.

29 L'Oreal SA v eBay International AG [2009] ETMR 53

30 Directive 2004/48/EC On the Enforcement of Intellectual Property Rights [Електронний ресурс]. - Режим доступу: http://eurlex.europa.eu/LexUriServ /LexUriServ.do?uri=CELEX: 32004L0048:EN:NOT.

31 McMahon B. Imposing an Obligation to Monitor on Information Society Service Providers / B. McMahon // Computer and Telecommunications Law Review. - 2011. - No. 17(4). - P. 96.

32 Bednarz T., Waelde C. Search Engines, Keyword Advertising and Trade Marks: Fair Innovation of Free Riding?in Edwards L.,Waelde C. Law and the Internet. /L. Edwards, C. Waelde. - [Third Edition]. - London: Hart Publishing, 2009. - P. 280. 
the author of the present paper supports this point of view, merely provides a virtual reality, where the keyword advertisers themselves are responsible for the decision to buy and use a certain keyword. It is practically impossible for the ISP to observe and check the origin of every keyword, as millions of advertisers use the system every day. The author, however, can provide examples of several German cases where the court held that the ISP could be held liable as an accomplice to trade mark infringement. ${ }^{33}$ In fact, in Internet Auction II ${ }^{34}$ the ISP was held liable for its inactivity after receiving a notice about an infringement. Thus, ISPs could be held liable for the nonprevention of overhanging possibility of infringement or its reiteration.

On the contrary, in the Belgian case Lancôme $v$ eBay ${ }^{35}$ the court held that the ISP had no responsibility to avert the infringement.

An additional argument can be found in the existence of Störerhaftung in German Law. This refers to the liability, which is a corollary of Internet law, when two people are held liable: a 'person who commits a trade mark infringement' and a 'person who causes a disturbance to the trade mark owner's rights. ${ }^{36}$

The point of Shaefer's article seems to be that the actions of ISPs have practical value when they result in trade mark infringement. To cut a long story short, the ISP can be found liable only in conjunction with the advertiser. ${ }^{37}$

The assumption being made by Matulionyte is that German liability standards seem to be higher than their French equivalents. The reason for this is a principle of acquiescence, whereby anyone who, consciously or by accident, facilitates an infringement is liable, as they have acquiesced to the act and have defaulted on a monitoring duty. The essence if this monitoring duty is to take 'technically and economically possible and reasonable measures'38 in order to prevent the infringement. Hence, there is a link between liability and monitoring duty in the German court practice. Thus, the ECJ in Google France ${ }^{39}$ stated that the ISP is not liable and is also

33 See Montres Rolex SA v Ricardo.de AG [2005] ETMR 25.

34 (I ZR 35/04) Internet Auction II [2007] ETMR 70.

35 L'Oreal SA v eBay International AG [2009] ETMR 53.

36 Bednarz T., Waelde C. Search Engines, Keyword Advertising and Trade Marks: Fair Innovation of Free Riding? In Edwards L.,Waelde C. Law and the Internet./ L. Edwards, C. Waelde. - [Third Edition]. - London: Hart Publishing, 2009. - P. 280.

37 Schaefer M. Kennzeichenrechtliche Haftung von Suchmachinen fuer AdWords Rechtsprechunsueberblick und kritishe Analyse / M. Schaefer // Multimedia und Recht. - 2005. No 8. - P. 808.

38 Matulionyte R., Nerisson S. The French Route to an ISP Safe Harbor, Compared to German and US Ways / R. Matulionyte, S. Nerrison // International Review of Intellectual Property and Competition Law. - 2011. - No 42 (1). - P. 66.

39 (C236/08-C238/08) Google France Sarl v Louis Vuitton Malletier SA [2011] ECRI-2417. 
immune from secondary liability if their role is passive and if they exercise no control over the keyword advertising. After the ISP is notified about a content of infringement though (Art. 14 ECD), it must check this immediately in order to prevent future infringements.

In French legal practice the ISP is the main defendant. Trade mark proprietors have received large sums for compensation from ISPs in all legal disputes that were decided in their favour. A good example is the Google France case, ${ }^{40}$ where the ISP was ordered to pay 300.000 Euro. This discrepancy can be explained by several reasons. First of all, it was Google who created AdWords and received a respectable yearly income of it. Secondly, Google plays an active role in choosing the keywords. In the French Courts of First Instance, in all three cases it was ruled that the ISP was liable for brand infringement under both TMD and CTMR.

The French Freedom of Communication Act 2000 in Art. 43-48 states that ISPs are liable for damages or infringements in respect of contents they host only when they did not diligently impede the access to this content after having been requested to by a judiciary authority.'41

What is more, Art. L. 713-3 of the Intellectual Property Code of France stipulates that:

„The following shall be prohibited, unless authorised by the owner, if there is a likelihood of confusion in the mind of the public: (a) The reproduction, use or affixing of a mark or use of a reproduced mark for goods or services that are similar to those designated in the registration; (b) The imitation of a mark and the use of an imitated mark for goods or services that are identical or similar to those designated in the registration." ${ }^{2}$

In the case of Google France ${ }^{43}$ the ISP retorted that it was 'neither the author nor co-author of the advertisements using the trade marks, ${ }^{\prime 44}$ i.e. keyword advertisers, as the proprietors of the linked websites, should be liable for the trade mark infringement.

However, the Court of First Instance did not take into account Google's arguments and held it liable for trade mark infringement, precisely because the ISP received profit from a trade mark sign, which was used for advertising

40 (C236/08-C238/08) Google France Sarl v Louis Vuitton Malletier SA [2011] ECRI-2417.

${ }_{41}$ Matulionyte R., Nerisson S. The French Route to an ISP Safe Harbor, Compared to German and US Ways / R. Matulionyte, S. Nerrison // International Review of Intellectual Property and Competition Law. - 2011. - No 42 (1). - P. 59.

42 Intellectual Property Code of France 1994 [Електронний ресурс]. - Режим доступу: http://lexinter.net/ENGLISH/intellectual_property_code.htm.

43 (C 236/08 - C 238/08) Google France Sarl v Louis Vuitton Malletier SA [2011] ECRI-2417.

44 Blakeney S. Keyword Advertising: Will the ECJ Provide an Answer? / S. Blakeney // Computer and Telecommunications Law Review. - 2008. - No 14(8). - P. 210. 
fake products. Furthermore, while typing the world 'imitation' AdWords nominated 'imitation Louis Vuitton.'45 Finally, the ISP was held liable for allowing the usage of signs of already registered trade marks.

Google has developed a function of keyword suggestions offered to users, which exploits algorithmic formulas. This process has led to situations whereby, while typing keywords corresponding to the names registered as brands, Google Suggest displayed the results together with words such as 'rape', 'satanic', 'prison' and others. The ISP argued that these search results could not be considered slanderous, as they were generated automatically by the service and without any human input. Subsequently, however, the ISP and its executive director were held liable for slanderous 'search suggestions' and 'defamation against individuals under the French law.' ${ }^{\prime 26}$ The decision was appealed on the grounds of the technically neutral character of Google's services with reference to the Google France judgement. ${ }^{47}$

Following the work of Lemperiere, the author of this paper concurs that it is hard for legislators to create new regulations that will be kept up-todate with technological innovations. The cost of some of these innovations overtops the amount of the fine imposed by the court. As a result it is more comfortable for ISPs to allege on the neutral character of service than to divulge the principles upon which its algorithms are based. The tendency to put the onus of evidence on the respondent, however, makes the protection of ISPs more complex.

It seems that ISPs should provide themselves with program software that will be able to reveal to users and the appropriate authorities the relevant information, in order to avert such pitfalls. Otherwise, the non-interference character of Google services may lead to greater problems.

It should be kept in mind, however, that the placement of new filtering programs can deprive ISPs of their exemption from liability, as 'mere conduits'.

Additionally, copyright law in Art. 8 (3) of Directive 2001/29/EC specifies that mark rights holders should have the opportunity 'to apply for an injunction'48 against ISPs, if their services are used by third parties to violate intellectual property rights.

45 Blakeney S. Keyword Advertising: Will the ECJ Provide an Answer? / S. Blakeney // Computer and Telecommunications Law Review. - 2008. - No 14(8). - P. 210.

46 Lemperiere M., Jobard A. 'M.X... v Google Inc., Eric S. and Google France' (Case Comment) / M. Lemperiere, A. Jobard // European Corporate Lawyer. - 2011. - No 11(1). - P. 5.

47 (C 236/08 - C 238/08) Google France Sarl v Louis Vuitton Malletier SA [2011] ECRI-2417.

48 Directive 2001/29/EC On the Harmonization of Certain Aspects of Copyright and Related Rights in the Information Society [Електронний ресурс]. - Режим доступу: http://europa.eu/legislation_summaries/information_society/data_protection/l26053_en.htm. 
To conclude, both the German and French Supreme Courts, in the number of cases they have tried, have proven reluctant to apply EU safeharbour provisions, and are keen to find ISPs liable under the most stringent national laws. ${ }^{49}$ As a result, the application of safe-harbour provisions differs between Member States: attention no longer focuses on whether these provisions are applicable, but on the ways that can be applicable. ${ }^{50}$

The evidence led to the conclusion that keyword advertisers will not escape from liability, if their products are identical to an already registered brand, even if they clearly mark them as "imitations” or "copies”.

In the Austrian Bergspechte case ${ }^{51}$ the ECJ held that trade mark proprietors can prohibit advertisers from using their marks, because it may affect their original function.

According to the legal practice of the Netherlands in the famous case Portakabin Ltd $v$ Primakabin $\mathrm{BV}^{52}$ the ECJ stated that advertisers can use trade marks as keywords according to the 'honest practices in industrial and commercial matters' for the sale of second-hand brand products. ${ }^{53}$ This means that keyword advertising issues should be decided by the national courts of Member States.

The Portakabin case differs from the aforementioned European cases as the reseller relabelled the product without the permission of the trade mark owner, who made the product and placed it on the market in the first place. Hence, brand concealment occurred. In this case, the question arose whether the resellers can conduct their business publicly by using trade marks and whether their performance will damage the brand's reputation. ${ }^{54}$

The ECJ's manual covered three dimensions: first, the advantages of unlimited Internet resale activities for resellers and their clients; second, full data as to the provenance of goods; and, third, made the point that

49 See Tiscali Media v Dargaud Lombard and Lucky Comics decision available at 〈http://www.droit-technologie.org/upload/actuality/doc/1294-1.pdf〉, an English translation can be found in 223 RIDA 456-466 (2010); (C-236/08) Hamburg Court of Appeal, 30 September 2009, Case No. 5 U 111/08 (Hamburg District Court), 2010 MMR 51 - Sharehoster II; Düsseldorf Court of Appeal, 27 April 2010, Case No. I-20 U 166/09 (Düsseldorf District Court), 2010 MMR 483 Rapidshare.

50 Matulionyte R., Nerisson S. The French Route to an ISP Safe Harbor, Compared to German and US Ways / R. Matulionyte, S. Nerrison // International Review of Intellectual Property and Competition Law. - 2011. - No 42 (1). - P. 73.

51 (C-278/08) Die BergSpechte Outdoor Reisen und Alpinschule Edi Koblmuller GmbH v Guni [2010] ECR I-2517

52 (C-558/08) Portakabin Ltd v Primakabin BV [2010] ETMR 52

53 ibid 9

54 'European Union: Council Directive (EEC) 89/104 of 21 December 1988 to approximate the laws of the Member States relating to trade marks, Arts. 5-7 - „Portakabin”' (Case Comment) (2011) 42(2) IIC 235. 
the advertising link should also propose the resale of products from other brands.

In answering the first and second questions the Court pointed out that the disposal of second-hand products is not a novel practice and is already known to customers as the kind of trade, where the reseller shifts the original label by the sticker replacing it with the name of reseller without giving any notice to the brand's proprietor. As a consequence, there is no any reference to the original brand, as the trade mark owners themselves are not interested in appearing as a party to a resale process. The ECJ concluded that on such occasions the original function of the trade mark (guarantee of the product's origin) is affected and the buyer has no opportunity to discern the origin of the product.

The Court's response on the third point was that under Art. 7 TMD in the reselling of second-hand goods, the reseller cannot be prevented by the trade mark owner from shifting the mark, unless the origin of the product is known to the customer, or there is lawful reason under Art. 7 (2) TMD. The following reasons can be considered legitimate: resale activities can adversely influence the brand owner's reputation; the consumer may think that there is a commercial link between the brand's possessor and the reseller.

It should be emphasized that the Dutch case differs from the aforementioned French ones, because here the questions that arose concerned the liability of the advertiser, but not of the ISPS. Meanwhile, in the Austrian BergSpechte case, ${ }^{55}$ the advertiser considered the use of the brand for the promotion of its own products.

From the author's point of view, it is worth mentioning that one of the findings of Bernardz and Waelde's work is that the lack of transparency in the ECJ's case law on the requirements of trade mark use may produce different results at the national level. As the ECJ has left a wide range of responsibilities to the national courts, it seems that these unresolved discrepancies will continue to produce different outcomes as to the liability of keyword advertisers. ${ }^{56}$ It can be assumed that national courts may want advertisers to refrain from the use of trade marks in the wording of the advertisement, by placing supplementary conditions.

${ }_{55}$ (C-278/08)Die BergSpechte Outdoor Reisen und Alpinschule Edi Koblmuller GmbH v Guni [2010] ECR I-2517

56 Bednarz T., Waelde C. Search Engines, Keyword Advertising and Trade Marks: FairlnnovationofFreeRiding?inEdwardsL.,WaeldeC. LawandtheInternet./ L.Edwards, C. Waelde. [Third Edition]. - London: Hart Publishing, 2009. - P. 308-309. 


\section{DEBT SECURITY OF THE STATE IN CYBERSPACE UNDER GLOBALIZATION}

Globalization (as an objective process), according to its content, reflects the world order which is changing and rather rapidly in further on the basis of world centers power moving and transformation processes, occurring in international, regional and national social and political systems ${ }^{1}$.

Globalization is a complex evolutionary process of formation, functioning and human civilization development, which is initiated and consolidated by epochal and basic innovations. It is focused that globalism is perceived by many people as a phenomenon of the end of $X X$ and the beginning of XXI centuries ${ }^{2,3,4}$.

Multi-network integration genesis research in world history suggests that globalization origins historically originate from "Neolithic revolution”, which became a basis of its first period, characterizing by mass military migrations and appearing of settlement-states (policies).

Now we know that before Greek policies there were Egypt, Sumer (Sumerian city-states Eris, Niptur, Uruk, Lagash and others about 5000 B.C.)

Modern globalization is a new qualitative state of post-industrial society or "the third wave”, after which follows „the forth one”, actualizing research of national and political systems' transformation problems and their staterod element ${ }^{5}$.

Globalization of the XXI century shows its integrative and consolidative features, encouraging scientific society of politicians and just „messengers" to forecast future with regional and world focal points ${ }^{6}$.

Every feature of globalization has its positive and negative properties, initiating challenges - mass impact over the state, its form of governing,

1 Яковец Ю. В. Эпохальные инновации 21 века / Ю. В. Яковец ; Межд. ин-т П. Сорокина Н. Кондратьева. - М. : ЗАО Издательство „Экономика”, 2004. - С. 2.

2 Бек У. Что такое глобализация? Ошибки глобализма - ответы на глобализацию / У. Бек ;пер. с нем. А. Григорьева, В. Седельника ; общ. ред. и послесл. А. Филиппова. - М. : Прогресс-Традиция, 2001. - С. 23-29.

3 Делягин М. Г. Мировой кризис: Общая теория глобализации : курс лекций / М. Г. Делягин. - 3 изд. - М. : ИНФРА-М, 2003. - С. 51.

4 Чумаков А. Н. Глобализация. Контуры целостного мира / А. Н. Чумаков. - М. : Проспект, 2005. - С. 346-405.

5 Тоффлер Э. Третья волна [Електронний ресурс] / Э. Тоффлер ; пер. на русс. яз.: А. Мирер, И. Москвина-Тарханова, В. Кулагина-Ярцева и др. - М. : Центр гуманитарных технологий, 2004. - Режим доступу: http://gtmarket.ru/laboratory/basis/4821.

6 Хаггер Н. Синдикат. История грядущого мирового правительства / Н. Хаггер. - М. : б. и., 2007. - С. 45-57. 
polity and state regime. Their classification presents methodological value. On this basis the main problems of the society should be revealed, prospects of modern state and their decisions should be determined as the likelihood of national security without them is reducing ${ }^{7}$.

One of the main features of globalization is open information space and close media interaction. Any beginnings or providing for a negative agenda can influence greatly on financial state stable, at the same time the image and rational strategy development and clarification of certain debt processes in the state, promotes its sustainable development and is an important component of national security.

In the conditions of globalization information can become one of the main protection instruments or the destruction of the basic principles state functioning, including the area of debt relations.

For a contemporary state the stability of financial system means state ability to fulfill its functions qualitatively in the event of unforeseen shocks of various natures, especially in the light of both economic and other crises of modern world, where clear definition of the scope and size of state debt and effective realization of debt function are determined as the most important state task.

In addition, it is considered very important how the information about these or other debts will be presented in cyberspace.

One of the most actively discussed issues is the problem of reduction of the powers of the state institution, which has lost a significant part of its traditional functions, some of which are „intercepted” by transnational and international structures and another part is transferred to local authorities and civil society.

According to I. Wallerstein, the main reason of state crisis of modern society is the loss of faith in the state as a "facilitator" of reforms and a bulwark of personal safety.

M. Castells believes that the crisis of the state legitimacy leads to a narrowing of the sovereignty of national states. Not only state institutions, but also traditional family values lose their authority and that leads to a disruption of sequence in the transmission of cultural codes from generation to generation. The state's withdrawal from such vital areas for a human as a social and cultural spheres, threatens with the loss of valuable sense of being.

In the opinion of Professor S.P. Peregudov, „the modern state has not surrendered its position of globalization, and its ability to manage the economy has not disappeared. But the forms of this management have changed, consequently its strategy, and therefore the „new role" of the state

7 Макуев Р. Х. Актуализация роли государства в обеспечении национальной безопасности в условиях глобализации / Р. Х. Макуев // Государство и право. - 2010. - № 8. C. 35 . 
in the globalized economy should not be evaluated as such that decreases or disappears at all, but it simply changes." The state's ability to make a positive contribution to economic development is not determined by its strength, but by its ability to create and maintain "network structures" in which, together with private group interests, it develops and implements an effective, coordinated and targeted economic management within and beyond national borders ${ }^{8}$. It should be noted that the debt function in this context contributes to the achievement of financial stability, and in the short term, to the price stability.

But despite the fact that there are serious contradictions and discrepancies in the conceptions about the role of the state in the global space, most researchers note a trend of weakening of the national state, the erosion of its borders and the destruction of traditional political relationships under the pressure of new political actors. We are talking about transnational subjects of power that displace national institutions and that are not controlled by the international political structures.

Globally oriented economy weakens the mechanisms of regulation of domestic policy, making the state controlled by the global financial markets whose interests are in contradiction with national interests. Economic globalization not only reduces the importance of the nation state, it undermines the national sovereignty and independence.

Particularly the importance for the legitimacy of the state is its inability to meet its obligations as a guarantor of national security.

Most modern researchers note that not all states can fit into the new economy successfully. International economic processes that previously successfully regulated bilaterally develop into the non-state relations, and therefore there are erosion and depreciation of the regulatory functions of the state. Information, financial and other processes associated with globalization, reduce the ability of national governments to control the political situation and its management.

Reinforcing its position transnational actors operate worldwide and don't recognize the borders that all increasingly undermine the ability of the nation state to ensure the welfare of citizens, at least partially deprives its traditional structures, technology of management and control.

Since the middle of last century there is the special role of the global financial system, the scope and force of impact on the national economy which were unprecedented. Cross-border financial flows linked so that the financial difficulties faced by one or more national systems can directly

8 Перегудов С. П. Новейшие тенденции в изучении отношений гражданського общества и государства / С. П. Перегудов // Полис. - 1998. - № 1. - С. 139-144. 
affect on other parts of the global financial system. The intensification of international trade relations has various consequences not only in economy. The development of regional trade agreements, global system, institutionalization change the role of the nation state, its protectionist functions significantly reduce not only trade tariffs and quotas, but internal politics are at the center of international institutions and organizations ${ }^{9}$.

The accumulation of sovereign debt, reaching historical highs in developed countries, leads to rethinking the challenges and threats to financial security in a global world. Despite the optimism, expressed (with caution) by experts in relation to the post-crisis global recovery, there is a belief in the duration of the problem of unloading financial imbalances.

Now scientific discussion is dedicated to a wide range of issues related to features of accumulating public debt and its management during a slowdown in global economic growth, the effective implementation of the debt function. Among the current research work should be called C. Reinhart and K. Rogoff ${ }^{10}$ considering problems of finding mechanisms to reduce sovereign debt, including financial repression, like any public policy measures that prevent the free market activities and also change the value of the debt or exchange rate.

The financial repressions include targeted credits from government to national entities with a help of administrative measures, explicit or disguised restrictions of interest rates, of capital flows, manipulation by economic conditions through a state share in banks.

Financial repressions are sometimes associated with an increase in reserve claims (or liquidity claims), taxation of securities transactions, prohibition of gold purchases or placing a large amounts of government debt at non-market rates. The main motive of financial repression is to increase the capacity of the state to finance debt to avoid appreciable consolidation.

On the importance of taking into account the features of credit and financial cycle in justifying measures of monetary, fiscal and macroprudential policies for the effective reduction of sovereign debt insist Aykman D., C. Borio ${ }^{11}$.

9 Васильева Т. Трансформация функций института государства в условияхглобализации / Т. Васильева // Власть. - 2007. - № 10. - С. 11-12;

10 Reinhart C. М. The return of financial repression [Електронний ресурс] / С. М. Reinhart // Financial Stability Review. Banque de France. - No 16. - April 2012. - Режим доступу: http://www.banque.france.fr./fileadmin/user_upload/banque_de_france/publications/Revue_ de_la_stabilite_financiere/2012/rsf-avril-2012/FSR16-article 04.pdf.

11 Aikman D. Curbing the credit cycle [Електронний ресурс] / D. Aikman, A. G. Haldane, B. Nelson. - Режим доступу: http://www.voxue.org/article/curbing-credit-cycle; Borio C. Macroeconomics and the financial cycle: Hamlet without the Prince? [Електронний ресурс] /C. Borio // VOX : Portal set up by the Centre for Economic Policy Research. - February 2, 2013. - Режим доступу: http://www.voxue.org/article/macroeconomics-and-financial-cycle-hamlet-without-prince/; 
Engineering tools and mechanisms to reduce the debt burden to avoid a sovereign default are considered in works of J. Kaiser, W. Panizzi, P. Bolton, D. Skil ${ }^{12}$ and others. Scientists emphasize the overall increased risk generated by international sovereign finance sector, and dangerous accumulation of debt capacity in the sovereign sector is considered as a trigger of reformatting the international financial architecture.

However, scientific and applicative researches of debt burden of international sovereign sector do not provide the definitive answers to solve debt problems. In this context, the relevance of question of the impact of globalization on the formation of public debt is in the conceptual definition of safe indicators of accumulation of public debt for the international and national financial systems and international areas of settlement processes.

The provision of a debt security of a modern state remains the most urgent area for discussion. The fact that the consequences of spreading public sector debt problems to other areas, the difficulty of obtaining reliable information about existing and potential risks of sovereign debt accumulation, identifying safe debt accumulation criteria for each individual country and the ability of states to meet debt obligations in proper time that's just a partial list of issues the delay in solving which strengthens global financial instability.

Trends of international debt-sovereign sector testify to the advanced rates of accumulation, it is the sovereign commitments, while other sectors level of debt held or even reduced. This trend may indicate the negative consequences of „saving” developed countries systemically important financial institutions and the practice of purchase of „toxic assets”. Appropriate steps significantly worsen the state of sovereign finances, so we should expect deterioration in the terms of borrowing in international markets for the sovereign sector, as well as the complications of finding sources of refinancing sovereign debt.

Should be also named a number of regularities of formation of public debt that can be tracked on the global market for public debt and securities. So, the developed countries, which have become the generator of the recent financial crisis, have traditionally played a major role in the accumulation of sovereign debt.

Of course, positive achievements are given for States of financial discipline and optimization of operating costs, achieved through fiscal consolidation. The growth of the debt burden indicates the absence of

12 Kaiser J. Resolving Sovereign Debt Crises: Towards a Fair and Transparent International Insolvency Framework [Електронний ресурс] / J. Kaiser // Friedrich Ebert Stiftung Study, September. - Режим доступy: http://library.fes.de/pdf-files/iez/07497.pdf Panizza U.Do we need a Mechanism for Solving Sovereign Debt Crises?/Panizza U. 
positive changes in addressing systemic problems - lack of economic growth to cover debt flows and the lack of mechanisms, given the financial, real debt reduction (restructuring only postpones the payment and, usually, worsens the General conditions of borrowing).

In this context, it is difficult to assess the safety of the global solution to the debt problems. The world Bank, the IMF, notes that slow economic growth is the main prerequisite for the emergence of risks. Therefore, the forecast of the world Bank referred to the significant potential negative impact of the Eurozone on the destabilization of the global market and the need for significant improvement in public finances, enhance the formation of panEuropean banking Union and sovereign rescue funds. In the event of a loss of political initiative in undertaking these activities, the world Bank predicts a high probability of limiting access some of the Eurozone countries to the international capital markets, as well as provoking a global slowdown that could reduce GDP of the economies that develop more than one percent.

Therefore, it is necessary to study the financial risks and improve their evaluation and the formation of a system of preventive measures. This work intensified international and national organizations, and supranational bodies that implement anti-crisis and preventive measures.

This certainly does not exhaust the global and national anti-crisis measures taken for refreshing sovereign finance and which are integral parts of the state debt function. We mention only one major trend - focusing on preventive measures - predicting and preventing crises. Any state in modern conditions of growing instability of the environment is important to ensure an effective system of research and crisis prevention, particularly in public sector debt. However, complexity and systemic nature of modern threats of international financial environment necessitates the improvement of scientific and applied study system solutions in security sector of government debt and improve the debt of state functions.

To reach this goal, it is important to prepare measures as follows: early diagnosis and prevention of financial imbalances; the most probable areas of research and transfer mechanisms of external crises, including the euro zone debt crisis into the national economic and financial system; forming debt-free sources of public debt repayment; compensative implementation of financing mechanisms of the economy in the event of a significant deterioration in external markets; optimizing sources of external funding and capacity to access international capital markets, including the development of modern financial mechanisms.

Thus, the global financial system has accumulated negative risk potential generated by the poor state of sovereign finances and slow economic growth. It 
actualizes the need for conceptual rethinking of the system to ensure financial stability of the modern state and prospects of sovereign debt accumulation for economic growth, as well as mechanisms to prevent transfers of financial crisis in the national economy. All of the mentioned above makes it necessary to prepare the premature answers to the challenges of international globalization, and pragmatic national security strategy can not be developed without resulting challenges of external and internal globalization factors affecting national security and function of the state debt ${ }^{13}$.

National security, an integral part of which is debt security, is the target object of the state protection and it represents socio-political elements consolidated by the globalization. The pragmatic strategy of the national security can't be developed without considering internal and external factors caused by the challenges of the globalization, as well as a developed strategy in the information field ${ }^{14}$.

It should be noted that globalization has a whole range of positive aspects in the process of influencing a country's debt. Thus, it opens new opportunities for the development as its contributes to the spread of the information, knowledge, new technologies, allows to use the benefits of the international labor division and industrial cooperation more fully than ever before, to use resources, loans more effectively etc. However, it exacerbates the existing contradictions in world, moreover, it generates new dangerous situations, conflicts and crises, leads to the increase of the public spending which, in its turn, results in the increase of the country's debt.

The process of the globalization manifested itself in the international and military sectors a long time ago, during the last decades it started to develop more dynamically in all the spheres of the social relationships, and, especially, economic ones. It is clear that without taking into account this the most important process it is impossible to predict the development of the country, elaborate the set of the state measures aimed at maintaining and strengthening the country's position in the international community.

On the other hand, the process of the globalization can significantly influence the formation of the new world order, decreasing the capacity of the national governments with certain countries' of the international community being dominant, as a result of their economic dependence.

Today it is noticeable that the public debt has increased dramatically and become almost the most painful point of the world economy. European

13 Базилюк Я. Б. Міжнародні боргові відносини як чинник глобальної фінансової нестабільності / Я. Б. Базилюк // Фінанси України. - 2003. - № 1. - С. 33-46;

14 Лутовитов В. И. К проблеме формирования стратегии национальной безопасности России / В. И. Лутовитов // Власть. - 2008. - № 10. - С. 16. 
Union countries found themselves in a difficult situation, Japanese public debt demonstrates new fantastic records as well as the difficult situation with US Treasury is obvious.

It should be noted that globalization leads to liberalization of financial accounts, which means the easy accumulation of public debt.

As the externalities of the global financial crisis there was an increase in the impact of globalization on monetary policy. In Ukraine it is noticeable in the ratio of hryvnia to other world currencies. Thus, it is necessary to determine the degree of exposure of the banking sectors as key drivers of monetary impulses in the globalization process as well as the consequences and prospects for the national economy.

Another factor enhancing the impact of globalization on the public debt is the monetary independence of modern states. It is actually an indisputable right to issue to a necessary extent. It must be admitted that even the increase of intensity of "real money”, in which assets in payments are transformed, leads to inflation, not to mention the increase in equity funds that not only leads to price instability, but also to imbalance of the economy as a whole.

Many economists have noted that financial globalization has a direct impact on the conduct of national macroeconomic and monetary policies, namely: to significantly limit the number of goals that can be achieved by the methods of monetary policy, gradual changes in the Toolkit of monetary policy.

Despite the negative aspects of globalization, we should note the close relationship between globalization processes and financial stability. At the same time support a balanced financial policy as well as creating a positive image in the information space in the long run promotes financial stability, and Vice versa, and in the short term can manifest contradiction of the need to ensure price stability with the requirement of maintaining stability of the financial system, in one form or another is an important factor influencing the debt security. 


\section{PRINCIPLES OF DCFR AS METHODOLOGICAL BASIS FOR IMPROVEMENT OF NATIONAL CIVIL LEGISLATION}

With this article, we begin a series of publications devoted to the consideration of one of the largest modern academic projects of codification of private law on the territory of the European space - Draft Common Frame of Reference (DCFR). The project is ambitious both in a figurative and in the literal sense of the word. This is confirmed by the history of its creation, which today continues to be written. In 2003, after the third part of the „Principles of European Contract Law" had been released, the expert group on the European Civil Code (The Study Group on a European Civil Code) was created. The Group includes academicians - the specialists in comparative legal study of private law in different legal systems of the Member States. The main purpose of the Group was preparing a codified set of principles of European law in the law of obligations and core aspects of ownership. These principles are expected to be published completely with commentary and comparative notes. ${ }^{1}$ So, by the initiative of the European legal scholars, through the years of research and exchange of knowledge between experts in the field of private law and the law of the EU the first edition of the DCFR was published in 2009. ${ }^{2}$

Our scientific interest in this project arises due to several arguments, the most important of which, in our opinion, may be the following. First of all, the maintenance and development of kindred relations between national civil law and private law of European countries is extremely important in terms of the ongoing process of globalization. Secondly, by the convergence of private-law institutions and legal systems of civil and common law, their interpenetration is an objective process of the present stage of development of private law. Adequate understanding of the "foreign" legal institutions and norms is impossible without their comparison with similar norms and institutions of the national legal system, the logical analysis of these norms and institutions and their application in practice. All these factors are taken into account by the developers of DCFR, among whom there are representatives of the Member States with legal systems of both civil and common law. Furthermore, the provisions reflected in the Project, provide the idea of the principles and their logic in a concentrated form, expressing the spirit of modern European

\footnotetext{
Study Group on a European Civil Code. Introduction // http://www.sgecc.net/pages/en/ introduction/index.introduction.htm

2 Principles, Definitions and Model Rules of European Private Law Draft Common Frame of Reference (DCFR). Sellier. European Law Publishers, Outline Edition, 2009. - 644 p. // http://ec.europa.eu/justice/policies/civil/docs/dcfr_outline_edition_en.pdf
} 
private law. DCFR as a project of extremely large scale (confirmed by the above provisions), is a collection of thoughts from various systematic issues of private law, a material, that is often outlined by various terminological languages based on definitions „acquis communautaire”. However, there is a reason to conclude that it is not about "systemic flaws”, but the improvement of the concept of private law in accordance with the modern vision of nature of the rights and interests of the individual, civil society and its values.

The changes, taking place in this area, found a consistent display in the approaches to the creation of important academic Draft Common Frame of Reference (DCFR) - Principles, Definitions and Model Rules of European Private Law and especially in its second edition - the full edition. ${ }^{3}$

The point, as we believe, in the idea of DCFR is the rejection of direct (positive) regulation of relations in the sphere of private law. Therefore, it is not the Civil Code of Europe. And, although one group of the developers of DCFR is called "The Study Group on a European Civil Code" (Working Group on the creation of a European Civil Code), but the other is called „The Research Group on EU Private Law" (Group survey of private law of EU).

Herewith, important is the fact that the result of the working group also has a long, eloquent title: Principles, Definitions and Model Rules of European Private Law, where in the first place is put „Principles”, and the rest of the text is the definition of concepts and examples of legal decisions concerning the regulation of relations in the sphere of private law.

Thus, it is not about creating legislative act. The aim of the study was a comparative legal research. And this is confirmed by the authors of DCFR - C. von Bar, E. Clive and P. Varul who say, that DCFR is to promote the study and understanding of private law in the countries - members of European Union. In particular, it is intended to show how similar to each other the national private law systems are, which can be regarded as a regional manifestation of European heritage. The task of the DCFR is to prove clearly the existence of European Private Law, referring to the relatively small number of cases in which various laws and orders give different answers to common questions. Thus, DCFR is regarded as that one, which can provide a new background for ideas of European private law, and, thereby, to increase understanding and help to brainstorm issues of private law in Europe. ${ }^{4}$

3 Principles, Definitions and Model Rules of European Private Law. Draft Common Frame of reference (DCFR). Full Edition. Prepared by the Study Group on a European Civil Code and the Research Group on EC Private Law (Acquis Group) / Ed. by Christian von Bar and Eric Clive. Vol. I - VI. Munich, 2009. - 4795 p. // http://ec.europa.eu/justice/contract/files/european-private-law_en.pdf

4 Кристиан фон Бар, Эрик Клив, Паул Варул. Предисловие к российскому изданию // Модельные правила европейского частного права / Пер. с англ.; Науч. ред. Н.Ю. Рассказова. М.: Статут, 2013.- Рр. 17-18] 
With this concept in the DCFR's triad „Principles, Definitions and Model Rules of EU private law”, „principles of EU private law” naturally occupy a prominent place.

Evaluating this category from the perspective of the problems of our study, we noted some differences in understanding domestic civil doctrine and use of the term „principles” in the text of the DCFR.

In domestic law in the most general terms, the principles of law are described as guidelines (ideas) to the content and direction of legal regulation of social relations. The significance of the principles of law is that they reflect the most essential features of law, its quintessence and "face" in a concentrated compressed form. ${ }^{5}$

The principles of law are also determined as starting ideas of existence of law, expressing the most important regularities and foundations of this type of state and law. They are single-order with the essence of law and constitute its main features. The principles are different by universality, supreme imperative and general significance, correspond to an objective need to build and strengthen certain social order. The features of the principles of law are: regulatory; internal unity that can be traced in their system-internal structural balance, consistency, integration and at the same time differentiation of certain types; their objective convectionality in line with the nature of social relations, economic, political, ideological processes in society; materialization in the law by direct wording of certain rules of law (textual consolidation) or withdrawal principles of the rights from the content of legal acts (substantive consolidation); their historicity. ${ }^{6}$

Among the general principles of objective law are: the principle of general binding rules of objective law for all social actors; the principle of consistency of the rules of objective law, which is part of the legal system and the priority of law in relation to other legal acts; the principle of separation of the legal system in general social law and legal law, and differentiation of the latest into public and private, substantive and procedural, regulatory and safety, objective and subjective law; the principle of correspondence between objective and subjective rights, between the rule of law and legal relationship, between the law and the process of its implementation; the principle of general formal legal equality of parties and at the same time their specific differentiation; the principle of justice, which in objective law gets manifested in equal scale of behavior assessment and legal liability under the offense and others. ${ }^{7}$

5 Юридична енциклопедія: В 6 т. /Редкол.: Ю.С.Шемшученко (голова редкол.) та ін. - К.: „Укр. енцикл.". - Т.5. - 2003. - С. 128

6 Колодій А.М. Принципи права України. Монографія. - К.: Юрінком Інтер, 1998. - С. 165

7 Там само. - С. 19, 21. 
Branches and institutions of private law, according to local lawyers, are built on the following principles: 1) the principle of autonomy (which means that subjects freely exercise their rights; interference in their affairs or counteracting is not allowed); 2) the principle of voluntariness (the subject himself is responsible for the performance of his duties; he is responsible for them by his own property, money, etc.); 3) the principle of legal equality (expressed in free will and its assessment that is equated to others); 4) the principle of discretionary; 5) the principle of coordination; 6) the principle of general authorization; 7) the principle of legal protection of private interests and others. ${ }^{8}$

Unlike general theoretical approach, in the Art. 3 of Civil Code of Ukraine it is referred to "general provisions of civil legislation”, which include: 1) the inadmissibility of arbitrary interference in the sphere of individual's private life; 2) the inadmissibility of deprivation of property rights, except as prescribed by law; 3) freedom of contract; 4) freedom of business activity that is not prohibited by law; 5) judicial protection of civil rights and interests; 6) fairness, good faith and reasonableness. Thus, according to the wording of the Art. 3 of CC of Ukraine, the given there list of general principles of civil law is exhaustive.

Matching the principles of private law, referred to in domestic literature, and principles (provisions) of civil legislation, mentioned in the Art. 3 of CC of Ukraine, it is possible to conclude that only two principles are considered as common: the principle of autonomy (with certain reservations which can be equated with the principle of the inadmissibility of arbitrary interference in the sphere of private life) and the principle of the rule of juridical (in paragraph 5 of the Article 1.3 of CC of Ukraine it is clarified as ,judiciary") protection of private interests.

Differences in the definition of the content and range of the principles of private law and provisins of civil legislation, give grounds for conclusion that the national law recognizes nonidentical concepts of „principles of private law”, „principles of civil law” and „provisions of civil legislation." The principles of civil law are based on the principles of private law, but do not coincide with them completely, as in civil law, unlike to private law, there are not only discretionary but mandatory elements (public contracts, non-contractual obligations, inheritance, etc.). However, it is possible to distinguish it as was done in the Civil Code of Ukraine by the „principles (general provisions) of civil legislation”. The last one is partly overlapped with the principles of civil law, and partly not.

Unlike domestic legal theorists and experts in civil law, the authors of DCFR focus not on the definition of the principles of law, on setting their

8 Колодій А.М. Принципи права України. Монографія. - К.: Юрінком Інтер, 1998. - С.176. 
range, etc., but start with warnings about the possibility of a different use of the term „principles”.

In particular, it is noted that in this context the term is used as a synonym for the expression of "rules which do not have the force of law." From this point of view we can say that the DCFR consists of principles and definitions. They are very similar by their nature to other documents, which are named „principles”.

However, the term „principles” can describe those rules which are of general legal nature, such as freedom of contract or good faith. From this point of view the DCFR's model rules also include principles. ${ }^{9}$

Attention should be also paid to the distinction in the DCFR the underlying principles andthe overriding principles, as through such differentiation it is focused on the main directions of development of private law concept.

As follows from the DCFR's text and comments of its authors, underlying are those principles that serve to ensure the most common goals of the DCFR. As these proposed principles of freedom, security, justice and efficiency (assuming that they also cover the principles of contractual loyalty, cooperation, etc.).

The definition of overriding principles is not given in the DCFR. Perhaps because it is about the term-concept, which is already a definition, and it serves as a characteristic for these principles. (To the point, the favorite technique of Roman jurists is to give specific list instead of abstract definitions).

The category of overriding principles of a high political nature includes protection of human rights, promotion of solidarity and social responsibility, preservation of cultural and linguistic diversity, protection and promotion of welfare and development of the internal market. ${ }^{10}$ (It should be noted that, according to the DCFR's authors, freedom, security, justice and efficiency, perform a dual role, acting also as overriding principles. Then it turns out that the principles are divided not into underlying and overriding, but into „overriding underlying” and „overriding not underlying”. This approach seems to be too complicated and can be explained, as we believe, by the fact that „overriding" principles relate to contract sphere, and here they are a priority. Overriding not underlying principles are of general nature, touching various aspects of life of European civil society.

Without dwelling here on the characteristics of overriding principles, it should be only noted that the priority of priorities can be considered the

\footnotetext{
9 Кристиан фон Бар, Эрик Клив, ПаулВарул. Предисловие к российскому изданию // Модельные правила европейского частного права / Пер. с англ.; Науч. ред. Н.Ю. Рассказова. М.: Статут, 2013.

10 Там же. - С. 21
} 
principle of protection of human rights, which is defined in the art. I.-1: 102 (2) of DCFR. This implies that the model rules are to be read in the light of any applicable instruments guaranteeing human rights and fundamental freedoms and any applicable constitutional laws. This overriding principle is reflected also in the content of individual model rules, especially rules on banning discrimination, contractual liability and others.

It is also of interest to provide priority support for the principle of promotion of solidarity and social responsibility, which, as exactly noted by the authors, is usually regarded as a function of public law. ${ }^{11}$ This position is explained by broadly interpreting the principles of loyalty and security of agreement that allows to engage a wide range of relationships in the field of contractual regulation. As for considering the principle of solidarity in relationships, arising from benevolent intervention in another person's affairs, this idea was known almost from the time of ancient Rome (though with some reservations), then it was actively discussed in the last century, and later received support even in totalitarian societies like the USSR . ${ }^{12}$

Practically important is the principle of preservation of cultural and linguistic diversity, which is a response to opponents of European integration, which intimidate by the loss of national cultural identity, etc., as well as to scholars who consider European integration from a purely pragmatic position to create a global competition in the „EU against the United States". ${ }^{13}$

In the latter case, the position of the DCFR's authors is more flexible. On the one hand, it is recognized that in a pluralistic world, such as Europe, the preservation of cultural and linguistic diversity is a condition for the existence of the Community. However, on the other hand - it should be taken into account that where human life has not only a cultural but a strong functional content, this principle may conflict with the principles of solidarity, protection and promotion of welfare and the promotion of the internal market (exemplified by serves, in fact, private law).

Consideration of these collisions resulted in a compromise solution to this problem, which is reflected in the fact that, along with the inclusion in some rules manifestations of the principle of preservation of cultural and linguistic diversity, it also has some concern in terms of the existence of the possibility of

\footnotetext{
11 Кристиан фон Бар, Эрик Клив, ПаулВарул. Предисловие к российскому изданию // Модельные правила европейского частного права / Пер. с англ.; Науч. ред. Н.Ю. Рассказова. М.: Статут, 2013. - Р. 23

12 Новицкий И.Б. Солидарность интересов в советском гражданском праве / И. Б. Новицкий. - Москва : Госюриздат, 1951. - 120 с.

13 Братимов О. В., Горский Ю. М., Делягин М. Г., Коваленко А. А. Практика глобализации: игры и правила новой эпохи. - М.: ИНФРА-М, 2000. - С. 157-214
} 
harmful effects on domestic market (and, consequently, welfare of European citizens and businesses) excessive diversity of contract law systems. In this sense, the purpose of DCFR is seen by its authors in the manual for the legislator, by which the meaning of European law can be made apprehensible to people who received a law degree in conditions of different law and order.

The value of the mentioned concern becomes more clear when one considers that the principle of protecting and promotion of welfare of citizens and entrepreneurs (and its complementary principle of uniform promotion of the internal market) deemed that covers all or almost all other principles. Because, as the authors point out, it implies the ultimate purpose and meaning of the DCFR. If DCFR does not help to improve the welfare of citizens and businesses in Europe - albeit indirectly, even slightly, albeit slowly - a project will fail. ${ }^{14}$

Evaluating the overall direction and content of the Draft Common Frame of Reference (DCFR) - Principles, Definitions and Model Rules of European Private Law, in particular the Principles, we can conclude that the crisis of the modern concept of private law, which detractors hope on, exists only in their imagination, and the mentioned concept, based on the fundamental values of European civilization in the twenty first century, is updated and further developed in accordance with the calls of Time.

The underlying principles of freedom, security, justice and efficiency ${ }^{15}$

The four principles of freedom, security, justice and efficiency underlie the whole of the DCFR. Each has several aspects. Freedom is, for obvious reasons, comparatively more important in relation to contracts and unilateral undertakings and the obligations arising from them, but is not absent elsewhere. Security, justice and efficiency are equally important in all areas. The fact that four principles are identified does not mean that all have equal value. Efficiency is more mundane and less fundamental than the others. It is not at the same level but it is nonetheless important and has to be included. Law is a practical science. The idea of efficiency underlies a number of the model rules and they cannot be fully explained without reference to it.

\section{Freedom}

\section{General remarks}

There are several aspects to freedom as an underlying principle in private law. Freedom can be protected by not laying down mandatory rules

14 Кристиан фон Бар, Эрик Клив, ПаулВарул. Предисловие к российскому изданию // Модельные правила европейского частного права / Пер. с англ.; Науч. ред. Н.Ю. Рассказова. М.: Статут, 2013. - p.23-25

15 Excerpts are given by: Principles, Definitions and Model Rules of European Private Law. Draft Common Frame of reference (DCFR). Full Edition. Prepared by the Study Group on a European Civil Code and the Research Group on EC Private Law (Acquis Group) / Ed. by Christian von Bar and Eric Clive. Vol. I VI.Munich, 2009. - 4795 p. // http://ec.europa.eu/justice/contract/files/european-private-law_en.pdf 
or other controls and by not imposing unnecessary restrictions of a formal or procedural nature on peoples' legal transactions. It can be promoted by enhancing the capabilities of people to do things. Both aspects are present throughout the DCFR. The first is illustrated by the general approach to party autonomy, particularly but not exclusively in the rules on contracts and contractual obligations. The assumption is that party autonomy should be respected unless there is a good reason to intervene. Often, of course, there is a good reason to intervene - for example, in order to ensure that a party can escape from a contract concluded in the absence of genuine freedom to contract. The assumption is also that formal and procedural hurdles should be kept to a minimum. The second aspect - enhancing capabilities - is also present throughout the DCFR. People are provided with default rules (including default rules for a wide variety of specific contracts) which make it easier and less costly for them to enter into wellregulated legal relationships. They are provided with efficient and flexible ways of transferring rights and goods, of securing rights to the performance of obligations and of managing their property. The promotion of freedom overlaps with the promotion of efficiency and some of these examples are discussed more fully below under that heading.

\section{Contractual freedom}

Freedom of contract the starting point. As a rule, natural and legal persons should be free to decide whether or not to contract and with whom to contract. They should also be free to agree on the terms of their contract. This basic idea is recognised in the DCFR. It is also expressed in the first article of the Principesdirecteurs. In both cases the freedom is subject to any applicable mandatory rules. Parties should also be free to agree at any time to modify the terms of their contract or to put an end to their relationship. These ideas are also expressed in the DCFR and in the Principesdirecteurs. In normal situations there is no incompatibility between contractual freedom and justice. Indeed it has been claimed that, in some situations, freedom of contract, without more, leads to justice. If, for instance, the parties to a contract are fully informed and in an equal bargaining position when concluding it, the content of their agreement can be presumed to be in their interest and to be just as between themselves. "Qui ditcontractuel, ditjuste”. In normal situations there is also no incompatibility between contractual freedom and efficiency. In general terms it can be assumed that agreements made by parties who are both fully informed and of equal bargaining power will be profit-maximising in the sense of bringing gains to each party (the exact division of the gain is a distributive question of little concern to economic analysis.) The only caveat is that the agreement should not impose 
costs on third parties (externalities). This is why in most systems certain contracts which are likely to have detrimental effects on third persons are rendered void as a matter of public policy.

\section{Non-contractual obligations}

Emphasis on obligations rather than freedom. The purpose of the law on benevolent intervention in another's affairs, on non-contractual liability for damage caused to another and on unjustified enrichment is not to promote freedom but rather to limit it by imposing obligations. Here we see the principle of freedom being counteracted by the competing principles of security and justice.

\section{Property}

Limited scope for party autonomy. The principle of party autonomy has to be considerably modified in property law. Because proprietary rights affect third parties generally, the parties to a transaction are not free to create their own basic rules as they wish. They cannot, for example, define for themselves basic concepts like „possession”. Nor are they free to modify the basic rules on how ownership can be acquired, transferred or lost. Under the DCFR they cannot even agree to an effective contractual prohibition on alienation. The free alienability of goods is important not only to the persons concerned but also to society at large. One type of freedom is restricted in order to promote another - and efficiency.

\section{Security}

\section{Contractual security}

The main ingredients. The Principes directeurs identify as the main ingredients in contractual security:

(1) the obligatory force of contracts (but subject to the possibility of challenge where an unforeseeable change of circumstances gravely prejudices the utility of the contract for one of the parties);

(2) the fact that each party has duties flowing from contractual loyalty (i.e. to behave in accordance with the requirements of good faith; to co-operate when that is necessary for performance of the obligations; not to act inconsistently with prior declarations or conduct on which the other party has relied);

(3) the right to enforce performance of the contractual obligations in accordance with the terms of the contract;

(4) the fact that third parties must respect the situation created by the contract and may rely on that situation; and

(5) the approach of „favouring the contract” (faveur pour le contrat) (whereby, in questions relating to interpretation, invalidity or performance, an approach which gives effect to the contract is preferred to one which does not, if the latter is harmful to the legitimate interests of one of the parties). 
Good faith and fair dealing. As the Principes directeurs recognise, one party's contractual security is enhanced by the other's duty to act in accordance with the requirements of good faith. However, the converse of that is that there may be some uncertainty and insecurity for the person who is required to act in accordance with good faith and fair dealing, which are rather open-ended concepts. Moreover, the role of good faith and fair dealing in the DCFR goes beyond the provision of contractual security. These concepts are therefore discussed later under the heading of justice.

\section{Non-contractual obligations}

Security a core aim and value in the law on non-contractual obligations. The protection and promotion of security is a core aim and value in the law on non-contractual obligations. These branches of the law can be regarded as supplementing contract law. Under contract law parties typically acquire assets. The protection of assets once acquired and the protection from infringement of innate rights of personality is not something which contract law is able to provide. That is the task of the law on non-contractual liability for damage (Book VI). A person who has parted with something without a legal basis, e.g. because the contract which prompted the performance is void, must be able to recover it. That is provided for in the law on unjustified enrichment (Book VII). In cases in which one party would have wanted action to be taken, in particular where help is rendered, but due to the pressure of circumstances or in a case of emergency it is not possible to obtain that party's consent, the situation has a resemblance to contract. But the security which would normally be provided for both parties by the conclusion of a contract for necessary services has to be provided by the rules on benevolent intervention in another's affairs (Book V).

\section{Property}

The provision of effective remedies. This is just as important as in contract law but the remedies are different. They are designed to enable ownership and possession to be protected. So the owner is given a right to obtain or recover possession of the goods from any person exercising physical control over them. The possessor of goods is also given protective remedies against those who interfere unlawfully with the possession.

\section{Justice}

\section{General remarks}

Justice is an all-pervading principle within the DCFR. It can conflict with other principles, such as efficiency, but is not lightly to be displaced. Justice is hard to define, impossible to measure and subjective at the edges, but clear cases of injustice are universally recognised and universally abhorred. 
As with the other principles discussed above, there are several aspects to justice in the present context. Within the DCFR, promoting justice can refer to: ensuring that like are treated alike; not allowing people to rely on their own unlawful, dishonest or unreasonable conduct; not allowing people to take undue advantage of the weakness, misfortune or kindness of others; not making grossly excessive demands; and holding people responsible for the consequences of their own actions or their own creation of risks. Justice can also refer to protective justice - where protection is afforded, sometimes in a generalised preventative way, to those in a weak or vulnerable position.

\section{Efficiency}

\section{Efficiency for the purposes of the parties}

Minimal formal and procedural restrictions. The DCFR tries to keep formalities to a minimum. For example, neither writing nor any other formality is generally required for a contract or other juridical act. There are exceptions for a few cases where protection seems to be specially required, and it is recognised that in areas beyond the scope of the DCFR (such as conveyances of land or testaments) national laws may require writing or other formalities, but the general approach is informality. Where the parties to a transaction want writing or some formality for their own purposes they can stipulate for that. Another recurring example of this aspect of the principle of efficiency is that unnecessary procedural steps are kept to a minimum. Voidable contracts can be avoided by simple notice, without any need for court procedures. Contractual relationships can be terminated in the same way if there has been a fundamental nonperformance of the other party's obligations. A right to performance can be assigned without the need for notification to the debtor. The ownership of goods can be transferred without delivery. Non-possessory proprietary security can be readily created. To be effective against third parties registration will often be necessary but, again, the formalities are kept to a minimum in the interests of efficiency. The rules on set-off can be seen as based on the principle of efficiency. There is no reason for $X$ to pay $Y$ and then for $Y$ to pay $X$, if the cross-payments can simply be set off against each other. Again, in the DCFR set-off is not limited to court proceedings and can be effected by simple notice.

\section{Efficiency for wider public purposes}

General. The rules in the DCFR are in general intended to be such as will promote economic welfare; and this is a criterion against which any legislative intervention should be checked. The promotion of market efficiency could be a useful outcome of the CFR project as a whole but that is not the aspect with which we are here concerned. The question here is 
the extent to which market efficiency is reflected in and promoted by the model rules within the DCFR. It is a matter of regret that the condensed time scale for the preparation and evaluation of the DCFR did not allow the evaluative work of the Economic Impact Group within the CoPECL project to be taken into account in the formulation of the model rules from the earliest stages. However, that evaluative work will form a valuable part of the corona of evaluation which will surround the DCFR and will be available to those taking the project further. What follows is a very brief note of a few areas in which it could be said that this aspect of efficiency is exemplified in the DCFR. 


\section{PART II. SPECIFICS \\ OF RELATIONSHIP BETWEEN IT-LAW AND INFORMATION SECURITY}

\section{IT TRANSACTIONS AND INFORMATION SECURITY}

The study of the specifics of the grounds for the emergence of legal relations in the IT field is important, since an accurate definition of the position on these issues will help to clarify their legal nature, will help determine the prospects for the development of legislation in the relevant field.

According to Part 2 of Art. 11 of the Civil Code of Ukraine, the main reasons for the emergence of rights and obligations are contracts and other transactions. There are transactions (in particular, contracts) which are the basis for the emergence of legal relations that mediate the dynamics of the IT sphere, giving the possibility for the active work to its subjects.

According to part 1 of Art. 202 of the Civil Code of Ukraine transaction is the action of a person aimed at acquiring, changing or terminating of civil rights and obligations. It is used to refer a source which is a factor that creates opportunities to do something, to use something, to behave in a certain way. The term "transaction” can be applied to the lawful actions of one person and the concerted actions of several persons. As a legal category, transactions are characterized by a combination of features that gives an opportunity to separate them from other legal facts. We can name the next main features of transactions: 1) always a willful act; 2 ) is an action aimed specifically for achieving a certain legal result; 3) is an action of subjects of civil (private) law; 4) always a lawful action. The se characteristics are common for all transactions, and therefore relate to transactions concluded in the IT field.

It should be noted that in the IT field, two- and multi-lateral deals (contracts) have been extended. In particular, these are IT-contracts for the provision of software services or its development; IT-contracts for work with PE or programmers; contracts with legal support for freelancers; contracts for the legal audit of IT companies; contracts for the sale of a site, domain, brand, etc.; any contracts concluded with the participation of online stores; Agreements on the legal maintenance of online stores; 
Concession contracts; License agreements; Agreements on joint activities in the sphere of IT-relations; contracts, the subject of which are intellectual property rights. All the mentioned contracts must comply with the general civil law requirements imposed by the current legislation to treaties, due to the universality of the category „contract” and its suitability for use in various areas of human existence, including the IT field.

At the same time, there is a kind of "feedback" between "IT-law" and transactions (contracts), which is manifested in the adjustment, with the help of its specific means, of "classical" requirements, signs, rules concerning the understanding of the essence, the order of concluding transactions, their form and so on. It happens due to the fact that the development of IT allows us to create new technological solutions and tools that simplify our life: both in carrying out simple everyday tasks, carrying out complex calculations, simulations, etc. Elementary processes of realization the basical legal relationships, including in the field of identification are also getting improved. Especially it concerns the transactions registration dynamics.

Civil Code of Ukraine (parts 1-3 Art. 207) defines the conditions according to which a transaction can be considered in written form, namely: if its content is fixed in one or more documents, letters, telegrams which are exchanged by sides; if the will of the parties is expressed by using a teletype, electronic or other technical devices of communication; if he is signed by the one party (parties). Transaction, which is committed by the legal entity should be signed by the individual who is authorized by the constituent documents, power of attorney, law or other law acts of civil legislation and should be sealed. Using facsimile reproduction of the signature during committing transactions with the help of mechanical or other copying, numerical-electronic signature or other analogue of a handwritten signature is allowed in cases, established by law, other acts of civil law, or in written consent of parties, which should contain appropriate analog samples of their handwritten signatures.

It means, that analysis of the current legislation indicates that using of identification as a tool for identification, is still necessary in the implementation of relevant legal relationships in electronic plane. Therefore, there is a practical need for an efficient system that clearly gives permission to perform certain actions, reserve information to the person who is entitled to receive such information or commit relevant transactions. In this case, it is impossible not to use electronic identification, which is connected with a person (which should be identified by totally different characteristics). 
However, the development and using in practice the electronic identification does not solve all the problems, there should also be legal consolidation of these operations and legal protection that are not perfect in the Ukrainian legislation and need revision and updating. It is a vital question because of the great and quick technical development. And the importance of the settlement of the processes of the indentification of individuals should be solved like the one of the main component for conclusioning the than sactions.

Currently, the legislator introduced into circulation such categories as „electronic signature”, „electronic digital signature” (hereinafter - EDS), "Passport of Ukraine in the form of the id-card with contactless electronic chip (and digital signature)" and, most recently, normative regulator - the National bank of Ukraine „Bank ID”. The law of Ukraine „On electronic commerce"2 was also introduced "signature by single identifier" and further defined „an analogue of a handwritten signature." In the process of development is another ID - Mobile ID, however, it remains legally unsettled, so its full using is still impossible.

The basic law in the field of electronic identification of people in the plane are the Law of Ukraine "On electronic commerce” in article 12 which states that where according to an act of civil law or by agreement of the parties electronic transaction should be signed by the parties. For its signature can be used an electronic signature or electronic signature under the Law of Ukraine "On electronic digital signature" if the use of digital signature means all parties electronic transaction, electronic signature single identifier as defined herein; analogue of a handwritten signature (facsimile reproduction of the signature by the means of mechanical or other copying other analogue of a handwritten signature) with the written consent of the parties, which should contain samples corresponding analogues of a handwritten signature.

According to art. 1 of the Law of Ukraine „On electronic digital signature” Electronic signature - it's a data in electronic form that are added to other electronic data or logically associated with them and are intended to identify such subscriber data; and digital signature - a type of electronic signature, obtained by the result set of cryptographic transformation of electronic data, which is attached to this set, or logically combined with it and allows you to confirm its integrity and to identify signer.

1 Горкуша М. Встановлення довіри до електронного підпису в Україні. - Режим доступу : https://ilaw.net.ua/vstanovlennya-doviry-do-elektronnoho-pidpysu-v-ukrajini/

2 Про електронну комерцію : Закон України від 03.09.2015 р. - Режим доступу : http://zakon3.rada.gov.ua/laws/show/675-19

3 Про електронний цифровий підпис : Закон України від 22.05.2003 р. - Режим доступу : http://zakon5.rada.gov.ua/laws/show/852-15 
In this context there is a need for more detailed examination of the notion of cryptographic information protection. This is due, in particular, to the fact that the gradual spread of influence of the state on internet, intensified the movement of cipher punks and cyberanarchist who stand for the right of private correspondence which will be guaranteed not by law on paper, but by mathematical laws, which won't affected by the state. The primary method of information protection offered by these tendencies there is the use of cryptographic tools that is special algorithms and systems of encryption, encoding or other transformation of information, in which its content become unavailable without a key and reverse conversion (decoding). With the help of such mathematical algorithms, the data can be encrypted in such a way that decryption will take a long time (for some algorithms - several thousand years), which will ensure security, and in most cases also anonymity in the network. ${ }^{4}$

In most countries activities related to cryptographic protection of information are subject to legal regulation. In Ukraine developments in the field of cryptographic information protection have also received legislative consolidation. In particular according to Article 7 of the Law of Ukraine "On licensing certain types of economic activities"5 activities related to the provision of services in the field of cryptographic protection of information subject to licensing.

Definition of basic notions in the sphere of cryptographic protection of information contained in the Regulation on the implementation of cryptographic protection of information in Ukraine approved by the decree of the President of Ukraine on $22^{\text {nd }}$ of may $1998^{6}$. Thus, cryptographic protection is a type of protection that is implemented using transformations of information with the use of special data (key data) to conceal (or restore) content of information, confirmation of its authenticity, integrity, authorship etc.

Despite the fact that the current legislation requires the licensing of developments in the field of cryptographic information protection, the activities of free developers (aka individuals without the status of an entrepreneur) remain uncontrolled by the state. Administrative sanctions for carrying out activities without a license to such entities are also applied

\footnotetext{
4 Горобець О. Криптография - свобода или препятствия. - Режим доступу https://ilaw.net.ua/kryptohrafyya-svoboda-yly-prepyatstvyya/

5 Про ліцензування певних видів господарської діяльності : Закон України від 02.03.2015 p. - Режим доступу : http://zakon0.rada.gov.ua/laws/show/222-19

6 Про Положення про порядок здійснення криптографічного захисту інформації в Україні : Указ Президента України від 22.05.1998 р.№505/98. - Режим доступу http://zakon3.rada.gov.ua/laws/show/505/98
} 
can not be applied, since the obligation to pass the licensing procedure rests solely on business entities. ${ }^{7}$

Thus, in Ukraine there are a lot of aspects of the use of cryptography at the legislative level, which remain unresolved. In particular, there are no rules governing the participation of a private person without the status of a business entity in the activities associated with cryptographic protection of information. Also, the question about the possibility of forced disclosure of encryption keys by users at the request of law enforcement remains open.

However, individuals who want to protect their own personal space from unauthorized intervention by the development and application of cryptographic algorithms and systems, in Ukraine have the opportunity to do this.

Returning to the consideration of digital signature, it should be noted that it is applied using the private key and verified using the public key. ${ }^{8}$ This corresponds to the general views on the technology of open and personal (closed) keys.

Each key is a set of characters or a file stored, for example, on usbflash drives. The difference is that the private key is top secret and stored at the owner (person who sings), and the public key is public. Other than the owner, it can be available to all participants, with whom he intends to exchange information using digital signature. On the public key to the certification authority (hereinafter CA) issues a certificate which confirms that the key belongs to its owner. ${ }^{9}$

According to art. 3 of the Law of Ukraine „About electronic digital signature" digital signature equivalent to a handwritten signature (print) if: it is confirmed with the use of reinforced key certificate by using reliable means of digital signature; while checking the used enhanced key certificate, valid at the time of imposition of the electronic digital signature; the private key of the signatory corresponds to the public key listed in the certificate.

As of the using of electronic signatures, here the main feature is that in its application in the work flow, the presence of a third party isn't necessarily, as in the case of use of EDS, where there is another entity - key certification center, which is responsible for the authenticity of the signature in the document, signed with EDS, which was supplied by them.

\footnotetext{
7 Горобець О. Криптография - свобода или препятствия. - Режим доступу https://ilaw.net.ua/kryptohrafyya-svoboda-yly-prepyatstvyya/

8 Про електронний цифровий підпис : Закон України від 22.05.2003 р. - Режим доступу : http://zakon5.rada.gov.ua/laws/show/852-15

9 Хілінський Ю. Як працювати з електронним цифровим підписом // Все про бухгалтерський облік. - 2005. - № 25. - С. 31-32.
} 
However, the question of the credibility of a particular CA, which provides services EDS is solved as follows: each center must undergo the registration procedure defined by the legislation, and witness your public key in the Central certifying authority (hereinafter - CCA). In this case, when checking the public key certificate of the signer, it is possible to ensure that CA, which had obtained a digital signature for signing the document, showed its public key in CCA, so you can trust him, and to trust that the document was signed by specified in the certificate face.

EDS actively use in their professional activities, according to the laws of Ukraine „On state registration of real rights to immovable property and their encumbrances” 10 , „On state registration of legal entities, individuals entrepreneurs and community groups"11, the state registrars of rights to immovable property and the state registrars of public persons, individualsentrepreneurs, notaries, courts and the other ${ }^{12}$. In addition, the Law of Ukraine „On amendments to some legislative acts of Ukraine concerning improvement of state registration of rights to immovable property and protection of property rights"13 ordered state registrars and notaries use the protected personal keys of the type „Crystal-1”, „Almaz-1K”, „SecureToken337M”, „SecureToken-337K” designed to enhance the security of a digital signature.

Characteristically, in accordance with the provisions of the act of Ukraine „On electronic digital signature” the electronic signature cannot be considered invalid just because it has an electronic form or not based on a qualified key certificate.

Analysis of the legislation gives grounds for conclusion that the use of electronic signature without an accompanying verification and determination of legal relations, where it can be used, it is impossible. The judicial practice evidences this.

Thus, the decision of the Supreme economic court of Ukraine from 12.10.2016 in case No. 916/16/16 on appeal PJSC CB „Privat Bank” for the decision of Economic court of Odessa region and the Odessa appellate

10 Про державну реєстрацію речових прав на нерухоме майно та їх обтяжень : Закон України від 01.07.2004 р. - Режим доступу : http://zakon5.rada.gov.ua/laws/show/1952-15

11 Про державну реєстрацію юридичних осіб, фізичних осіб - підприємців та громадських формувань : Закон України від 15.05.2003 р. - Режим доступу : http://zakon2.rada.gov.ua/laws/ show/755-15

12 Голубєва Н.Ю. Ви ще не використовуєте електронно-цифровий підпис? А виявляється, що і він вже „застарів”... - Режим доступу : https://kievskiysud.od.ua/press-department/allnews/3944

13 Про внесення змін до деяких законодавчих актів України щодо вдосконалення державної реєстрації прав на нерухоме майно та захисту прав власності : Закон України від 06.10.2016 р. - Режим доступу : http://zakon2.rada.gov.ua/laws/show/1666-19 
economic court on the claim of PJSC CB „Privat Bank” to debt recovery to the self-employed individual, it is established that the plaintiff has not provided any evidence that the SEI has signed by the electronic digital signature the declaration of accession to the conditions of the loan set forth in the rules and regulations for the provision of banking services, rates of the Privat Bank, as the plaintiff not given nor information about the certification of EDS key of the defendant, nor information about the personal key of the signer, which should correspond to the public key listed in the certificate. In this case, the defendant denies the fact of signing this application ${ }^{14}$.

Also, the courts previous instances have rightful conclusion that PJSC CB „Privat Bank” has not proven fact of the conclusion of the agreement between the parties of the banking service, which in turn indicates that the parties have not agreed the size and conditions of the provision and the return of the money. At the same time, the legal basis of the claim is just giving the defendant the loan contract concluded in accordance with the conditions and rules for banking services, while the plaintiff has not proven validity use the defendant credit funds of the Bank.

In addition, the application of electronic signature required compliance with additional conditions, established by law or other acts of civil legislation: the written consent of the parties, which should contain samples of appropriate counterpart of their holograph signatures; use an electronic digital signature is made by all the parties to an electronic transaction (art. 12 of the Law of Ukraine „On electronic commerce”).

Thus, the electronic signature generated the usual graphic reproduction may not be recognized as a full-fledged and legal analog of a handwritten signature, despite the fact that his electronical nature, or the lack of enhanced certificate key can not be the reason for recognizing it not valid. The use of electronic signature, considering this legislative regulation, is quite hard, but otherwise it is impossible to form grounds for confidence in the electronic signature.

However, the technology of electronic signature continues to develop dynamically. Currently there is already operating services that help to establish additional reason to trust the person who put on the document his electronic signature. In this case, the authenticity of the electronic signature is checked by other parties of the transaction by previously known identifiers, in accordance with which they can identify obtained signature with the person who is specified by the set of data, added by the provider to the electronic signature.

14 http://www.reyestr.court.gov.ua/Review/62024404 
For example, such verification may take place by phone number, or e-mail address that is specified with registration in the system of provider services for electronic signature. Obligation of the provider is to check using a special linkactivation profile and one-time SMS password authenticity specified additional IDs and their belonging to the person who has created an account in the system.

However, the corresponding risk of compromise of the electronic signature remains, although it is difficult to imagine a simultaneous unauthorized access to e-mail, and mobile phone, in spite of the fact that separate services register users in the system providing electronic signatures solely on the basis of the specified at registration e-mail. ${ }^{15}$

So in may 2016 property owners were very concerned about the statement of the Chairman of the Department of the Notary chamber of Ukraine in the Sumy region of Larissa Voloshin that notaries recorded the unauthorized registration activity in the State register of rights to immovable property. "According to the words of the private notary of the Sumy city notarial district Oksana Yurevna Assor, in the period from 13 April to 28 April 2016 by unauthorized persons by the use of her user ID and password was carried out unauthorized registration activity in the State register of rights to immovable property"16. The Minister of justice of Ukraine Pavel Petrenko on this occasion assured that these facts are not true and some notaries are not very disciplined: they give keys to their assistants. On his behalf this information was checked, and any external entries in the registry were not detected..$^{17}$

However, according to the experts of the NGO - lab CyberLab computer forensics, attackers do not need to break the registry. "They work differently, first with a „viral” software gain access to computers, notary, and then kidnap their key of access to registers. And log in for these keys. It is clear that the system does not accept this session as wrong" (Sergei Prokopenko, Director of the CyberLab) ${ }^{18}$.

Scheme of attack on the computer of the notary looks like this: first, hackers send an email disguised as an official newsletter of the Ministry of justice. Then the hackers start to monitor the computer and the actions of the notary to find programs and personal data to access the real estate register. When the required data is found, the criminals kidnap them and then use for their own purposes.

15 Горкуша М. Встановлення довіри до електронного підпису в Україні. - Режим доступу : https://ilaw.net.ua/vstanovlennya-doviry-do-elektronnoho-pidpysu-v-ukrajini/

16 http://100realty.ua/uk/news/41132

17 http://sts.sumy.ua/politics/ministr-yustitsiyi-doruchiv-pereviriti-skandalnogo-notariusa-iz-sum.html

18 http://glavcom.ua/publications/divni-ruhi-neruhomosti-yak-v-ukrajini-kradut-chuzhuvlasnist-354467.html 
Hackers do not have aim to connect to computers of any specific notaries. They spend a mass mailing, and then treat those who got cought. However, as noted in the CyberLab ${ }^{19}$, to improve the efficiency crackers use "social” stealth. For example, in the subject line of a letter indicate „Complaint against the notary or court Decision." Also, criminals have learned to „substitute” as the sender's real address with the domain name of the Ministry of justice - some notaries have received emails from addresses that have the format @minjust.gov.ua.

About the possibility of hacking access to the registers through the appropriation of key evidence let us know the production of the Odessa district administrative court regarding a private notary from Rivno Sergey Kucicom by records in the State register of proprietary rights to immovable property encumbrance of all real property LLO „Odessa oil extraction plant”. The notary denied any involvement in to these registration actions, and said that he previously appealed to the Rivne branch of SE „National information system" with a request to suspend access to Unified and State registers by his user ID, password and digital signature key, and also filed a statement about the crime to the police of Rivne. ${ }^{20}$

There is another scheme to access the registry of real estate on which „the notary gives the right people the passwords and the key, gets on the plane and leave the country. Absence from the country provides him with an alibi for the time when there are illegal changes in the registry of the notary." ${ }^{21}$

So, despite the constant signals about third-party access to the Unified and State registers, the active concern of society for this reason, the Verkhovna Rada of Ukraine 06.10.2016, as mentioned, complemented by article 5 of the Law of Ukraine „On electronic digital signature”, and shall state registrars of rights to real estate, business, notaries public only use secure carriers of private keys. Checking the information required for registration and formation of the reinforced key certificate subscribers is carried out exclusively by their personal presence.

Another introduction in electronic ID in the Ukrainian legal framework is currently disposable electronic signature identifier. ${ }^{22}$ The Law

19 http://glavcom.ua/publications/divni-ruhi-neruhomosti-yak-v-ukrajini-kradut-chuzhuvlasnist-354467.html

20 http://www.reyestr.court.gov.ua/Review/56575993 та http://www.reyestr.court.gov.ua/ Review/56723500

${ }^{21}$ http://glavcom.ua/publications/divni-ruhi-neruhomosti-yak-v-ukrajini-kradut-chuzhuvlasnist-354467.html

22 Горкуша М. Правові засади регулювання ідентифікаторів в Україні. - Режим доступу : https://ilaw.net.ua/pravovi-zasady-rehulyuvannya-identyfikatoriv-v-ukrajini/ 
disposable electronic signature identifier is defined as „data in electronic form in the form of alphanumeric sequences that are attached to other electronic data by the person accepting the offer (offer) to conclude an electronic contract, and sent to the other party of this agreement. ${ }^{23}$

Consequently, a situation arises when the person who accepted the offer at the stage of confirmation of conclusion of the relevant electronic agreement will receive a one-time code, which subsequently enter it to confirm the conclusion of such an agreement. This method seems quite reasonable, because there is a check contact number, and establishes the fact of will concerning the conclusion of such contract.

However, in the general "chain" chain of providing an enforcement of the contract, the obligation of identification relies on the acceptor - customer products or services. This conclusion can be made on the basis of part 8 art.11 of the law, which says that in the case where the electronic contract signing takes place in the information and telecommunication systems of e-commerce subject, to accept the offer to conclude a contract, the person has to identify in such a system and to respond to the proposal. In other words, it is a seller's registration on the website indicating respective identifiable data necessary for the conclusion of an electronic contract, including name, mobile phone number (in the context of electronic signature electronic identifier), e-mail and other data.

However, the store still can not validate the parameters for identification. After a message with a single identifier will be sent to a specified person mobile phone without identification. In fact, will only confirm the will of the person specified subscription details. Instead, set the actual ownership of the data of specified person is impossible.

In addition, in the context of search using more safe option should be mentioned that there is another identifier for a more versatile value and one that contains the same digital signature - a citizen card or ID-card that Ukrainian legislation reflected a passport Ukraine in the form of cards with contactless electronic media. According to the Law of Ukraine „On the Unified State Register of demographic and documents that prove citizenship of Ukraine identity or her special status" (Part 7, Art. 21), to such a passport will be made following information: the name of the state; title of the document; name of a person; male or female; citizenship; date of birth; unique entry number in the Register; document number; expiration date of the document; date of issue of the document; authorized entity that issued the document (code); Place of

23 Про електронну комерцію : Закон України від 3 вересня 2015 р. № 675 VIII // ОфіційнийвісникУкраїни. - 2015. № 78. 
birth; Digitized image (picture) face person; Digitized signature of the person; tax nomer. ${ }^{24}$

While issuing cards or citizen ID-cards are made, however, electronic signature or electronic signature laid there. Thus, although the announcements of the State Migration Service, a digital signature that is on the card, will greatly facilitate the work in the process of identification, his identification when carrying out certain operations, however, given the information that will document in accordance with the law is not clear whether it be conventional electronic signature technology, whether it EDS. ${ }^{25}$

Thus, we can conclude that the use of electronic signature and digital signature will only spread, so in order to prevent violations of the rights of people who use them, and the most effective use of them it is needed to finalize certain legal acts.

24 Про Єдиний державний демографічний реєстр та документи, що підтверджують громадянство України, посвідчують особу чи ії спеціальний статус: Закон України від 20.11.2012 p. - Режим доступу : http://zakon2.rada.gov.ua/laws/show/5492-17/print1475414381969190

25 Горкуша М. Правові засади регулювання ідентифікаторів в Україні. - Режим доступу : https://ilaw.net.ua/pravovi-zasady-rehulyuvannya-identyfikatoriv-v-ukrajini/ 


\section{PROBLEMS OF COPYRIGHT PROTECTION FROM INFRINGEMENT ON THE INTERNET}

With establishment and development of the information society information and communication technologies, which allow to collect, process, receive and send information at local, national and international levels, become more and more important. The Internet, the largest telecommunication network in the world, that began to emerge in 1969, plays a key role among these technologies. Establishment of the single global information space allows today to transmit any kind of information, which is not accessible, to anyone who has personal computers and, with the help of satellite, from every point on the planet. However, the development of the Internet creates a lot of problems in the field of intellectual property. Taking into account peculiar properties of the Internet it is rather difficult to protect intellectual property rights within the network. According to experts, by 2020 about $75 \%$ sensitive data could not be protected. In addition, the technology of 3-D objects copying becomes a reality and very soon, as it is predicted by Gartner analyst firm, loss of companies-rightsholders from massive theft of intellectual property by means of this technology will make annually at least 100 bln. dollars. ${ }^{1}$

Thus, in the information society significantly increases the necessity to ensure the protection of intellectual property rights in general and the rights of the author, particularly, on the Internet. Before dealing with related challenges it is necessary to study and analyze main categories regarding operating of the web.

Although the problems of legal regulation of relations arising on the Internet have been the subject of scientific analysis, ${ }^{2}$ a significant number of issues still remain insufficiently studied from the perspective of protecting the rights of the author in this field. Due to this it is important to study relevant issues in order to establish the essence and legal nature of the web,

\footnotetext{
Полоса О. Технологія 3-D копіювання змінює світ // Інтелектуальна власність. - 2013. № $10 .-$ С. 73 .

2 Присяжнюк О.А. Основи концепції правового регулювання інтернет-відносин в Україні (загальнотеоретичні аспекти): Дис. ... канд.юрид.наук. - Х., 2007. - 163 с.; Ващинець І.І. Цивільно-правова охорона авторських прав в умовах розвитку інформаційних технологій. Автореф. Дис. ... канд. юрид. наук. - К., 2006. - 20 с.; Рассолов И.М. Право и Интернет: теоретические проблемы. / И.М. Рассолов - Дис. ... докт. юрид. наук. - М., 2008. - 357 с.; Глушков А.В. Проблемы правового регулирования интернет-отношений. / А.В. Глушков Дис...канд..юрид.наук. - Санкт-Петербург, 2007. - 198 с.; Мамон 3.В. Деякі аспекти захисту авторських прав у мережі Інтернет .- Режим доступу: http://www.yurlex.com.ua/print/ua/company/contact/index.htm.
} 
features of subjects and objects of relevant legal relations and, therefore, features of protection the rights of their participants. The aim of the article is to analyze the main legal categories that are the key one in this area, to define their place and importance in the system of copyright protection.

First of all, it should be noted that there is no definition of such fundamental concept as "Internet” in international acts. Recommendation of the International Telecommunication Union (hereinafter - the ITU) "Global Information Infrastructure terminology: Terms and definitions" gives following technical definition of the Internet: a collection of interconnected networks using the Internet Protocol which allows them to function as a single, large virtual network. The Handbook on Internet Protocol (IP)Based Networks and Related Topics and Issues, which has been developed by ITU Council, characterizes the Internet as a logical architecture that is independent of any particular network, but which permits multiple different networks to be interconnected in such a way that computers and people can communicate without the need to know which network they are using or how to route information to them. In other words, the Internet is a conceptual creation consisting of protocols and procedures, which are then used by the constituent networks to interconnect. This notion was captured in a definition by the United States Federal Networking Council (Resolution 1995), as submitted to the United Nations Working Group on Internet Governance with a proposed amendment to reflect the evolving nature of the Internet. ${ }^{3}$ The definition of "Internet" is enshrined in Article 1 of the Law of Ukraine „On Telecommunications”, according to which it is the world information system of general access which is logically connected by global address space and the Internet Protocol established according to international standards. Under information system of general access it is meant a series of telecommunications networks and facilities for storage, processing and transmitting data.

Various definitions of the Internet are offered in the literature. In particular, the Internet refers to the global system of united computer networks, which serves for storage, transportation and other activities dealing with information and which allows to access information regardless of its location. ${ }^{4}$ It is also proposed to define the Internet as the global network of computer resources with public access using a single

3 Справочник по сетям на базе протокола Интернет (IP) и соответствующим темам и вопросам [Електронний ресурс] / Международный союз электросвязи. - Женева, 2005. Режим доступу : http://www.itu.int/dms_pub/itu-d/opb/hdb/D-HDB-IP-2005-PDF-R.pdf.

4 Право інтелектуальної власності: посібник / за ред.. Р.Б. Шишки (кер.авт.кол.) та інш. К. : „МП Леся”, 2014. - С. 149; Сопілко І.М., Пономаренко О.В. Захист авторських прав в мережі Інтернет : монографія. - К. : Компютерпрес, 2013. - С. 77. 
standard addressing scheme of high-speed communication lines to the main network computers. ${ }^{5}$

Analysis of the above definitions leads to the conclusion that all they characterize the Internet primarily as technical means of information transfer, focusing on the technical side of the network, leaving aside legally significant aspects.

Speaking of the Internet as a legal category, it should be noted that there is no single approach to determining its legal nature in the legal doctrine: whether it is an object of rights or a subject or an object of legal regulation.

Considering the potential ability for the Internet to serve as an object of law, most scientists eventually come to the conclusion about the absence of sufficient grounds for declaring this statement true because of the fact that the Internet in general can not belong to anyone on the right of property and can not be an object of civil circulation. Indeed, the software used on the Internet, belongs to its developers; digitized works of science, literature, music performances, etc. placed on the Internet belong to their rights holders; computer equipment used for access to the Internet belong to the users; servers belong to specialized companies. The Internet is not an object of law as a kind of property or an object of intellectual property, the Internet can not be sold or bought.

Talking about the ability of the Internet to be a subject of law, it should be understood that the network does not possess such common features of the legal entity, such as: organizational unity, the presence of separate property, the ability to participate in civil circulation on its behalf and the ability to be a plaintiff or defendant in court. The absence of organizational and structural design of the Internet as a specific organization is proved by the fact that there is no single network management as well as there is no single organization that owns, manages or controls the Internet. There are some non-profit organizations that provide operation of the Internet, including, in particular, the Internet Corporation for Assigned Names and Numbers (ICANN), responsible for the global coordination of the unique elements of the network system and safe and stable operation of the organization; Internet Society, which promotes the development of the Internet, the development of new Internet technologies and ensuring the availability of the World Wide Web on a global scale; Internet Architecture Board (IAB), which oversees the architecture of the Internet, including its protocols and associated procedures, and the creation of new Internet standards and includes an engineering group that is addressing technical

5 Глушков А.В. Проблемы правового регулирования интернет-отношений. / А.В. Глушков - Дис...канд..юрид.наук. - Санкт-Петербург, 2007. - С. 17. 
issues Internet (IETF) and the research team (IRTF). The Internet has no property-based autonomy because, as it has been noted above, the material (technical) and immaterial resources of the network are owned by different entities. There is also a view that all users involved in Internet technology communication form the Internet Society as a social structure. However, there is no sufficient basis for the identification of the entire Internet with the Internet community and presenting in this way the features of the Internet as an entity. Therefore, denying the presence of general features of the object and the subject of law of the Internet, it is compared with usual material (real) medium and for its research the model of information sphere is used. ${ }^{6}$

Listing the main characteristics of the Internet, which in our opinion are important for understanding the essence of this phenomenon, will help us to formulate a definition of the Internet as a legal category.

1. The Internet is an information and telecommunications network. As it is noted by S.V. Petrovskyi, the term "information network”, which sometimes is used to refer to the Internet, is not accurate because does not specify neither form of the information that is transmitted or the subjects of transfer and may cover both technical and social formations that provide information transfer. ${ }^{7}$ However, apart from the Internet, there are other multi-service networks, which are also based on the protocol IP, such as Next Generation Network. In this regard, the doctrine fairly draws attention to the importance of determining on technical level differences between the Internet and other similar networks that use similar software and technology, but are not the Internet ${ }^{8}$.

2. The Internet is a global computer network that connects millions of users worldwide in over 150 countries using various communication channels. The global character of the Internet allows to spread quickly throughout the network any intellectual property objects rights in digital form over long distances. The text file can be sent in seconds to any place of the world via e-mail or other computer systems of instant messaging on the Internet. ${ }^{9}$

6 Копылов В. А. Информационное право : учебник / В. А. Копылов. - 2-е изд., перераб. и доп. - М. : 2002. - С. 94.

7 Петровский С. В. Интернет-услуги в российском праве / С. В. Петровский. - М. : Агентство „Издательский сервис”, 2003. - С. 10.

8 Пазюк А. В. К вопросу о необходимости определения термина „Интернет” в международном праве [Електронний ресурс] / А. В. Пазюк. - Режим доступу : http://iir-kiev.academia.edu/AndriiPaziuk.

9 Сопілко І.М., Пономаренко О.В. Захист авторських прав в мережі Інтернет монографія. - К. : Комп'ютерпрес, 2013. - С. 150. 
3. The Internet provides universal access to users. Adopted at the 32nd session of the General Conference of UNESCO Recommendation concerning the promotion and use of multilingualism and universal access to cyberspace provides a number of measures to ensure such access: developing appropriate policies by Member States and international organizations; the establishment of local, national, regional and international mechanisms that promote universal access to the Internet through affordable prices for telecommunications and Internet services; encouraging ISPs to provide preferential tariffs for Internet access to certain categories of users. In addition, the right of access to the Internet as universal (public) service is established in the Directive of European Union on universal service (2009/136/ EU), which states that everyone in the EU should have access to a minimum list of electronic communications services of good quality and affordable price, including access to the Internet. In the literature even the question of the recognition of the right of access to the Internet as an independent constitutional (basic) right has been raised. ${ }^{10}$ In most countries using the Internet does not require any administrative formalities. Potential users should only have technical ability to connect to the network. Under the legislation of Ukraine public (universal) telecommunications services are defined as services of certain minimum set of standardized quality, which are accessible to all consumers throughout Ukraine. However under Art. 62 of the Law of Ukraine "On Telecommunications" list of such services does mention access. Of course, this situation is unacceptable and needs to be brought in accordance with international recommendations and standards of the European Union.

4. One of the principles of information exchange on the Internet is the anonymity principle enshrined in the Declaration on freedom of communication on the Internet adopted by the Committee of Ministers of the Council of Europe on 28 May 2003. Anonymity means that in order to ensure freedom of expression and the exchange of information and protection of network surveillance the will of users not to disclose their identity should be respected. Anonymity also provides possibility of elimination any traces of your activities on the Internet. However, the emergence of dynamic IP-addresses and special software capable of hiding or showing fake instead of real note as well as anonymity have raised the problem of using the Internet on behalf of others. ${ }^{11}$ However, despite the proclaimed principle

10 Середа М. Ю. Закрепление права на доступ в сеть Интернет в международно-правовых актах и законодательстве зарубежных стран / М. Ю. Середа // Международное публичное и частное право. - 2013. - № 5. - С. 45.

11 Сопілко І.М., Пономаренко О.В. Захист авторських прав в мережі Інтернет монографія. - К. : Компютерпрес, 2013. - С.152. 
of anonymity arises the question of identification of users of the global network, operators of services provided by using the Internet and owners of information placed on the Internet. In this regard, at the international level should be clearly defined acceptable limits of anonymity on the Internet and outlined the cases of legal restrictions.

5. The Internet has a complex multi infrastructure, acting as a multilayer, multi-level formation, an association of multi-level networks. At the lowest level there are physical infrastructure, communication channels, infrastructure access, than goes the address space (IP-address), above which there is domain name system DNS, and on the uppermost floors of the hierarchy of the Internet there are mail services, search engines, websites etc. ${ }^{12}$ Functioning of basic components of such infrastructure lays under the jurisdiction of individual states, which establish the legal regime of infrastructure and the order of their use. ${ }^{13}$ Network architecture is based on the principle of multi-level messaging: at the top level of reference model of open systems ISO/OSI interacting a message is formed, than it goes through all equal levels of the system to the lowest level (physical), on which it is transmitted to the addressee.

6. The functioning of the Internet has transboundary nature that requires transborder network management control while within national jurisdictions issues of using the Internet should be regulated. Thus, Internet Assigned Numbers Authority (IANA) performs such functions, as the coordination of the assignment of technical Internet protocol parameters performed by the Internet Engineering Task Force (IETF); the administration of certain responsibilities associated with Internet DNS root zone management; the allocation of Internet numbering resources to the Regional Internet Registries (RIRs); and other services related to the management of the .ARPA and .INT top-level domains. In addition, among key organizations involved in transboundary management of the technological infrastructure of the Internet, there are five regional Internet registrars responsible for the destination IP-address to the end users in certain areas, as well as local Internet registrars, such as the Internet Providers. Administration of address space of the Ukrainian Internet segment is carried by associations of enterprises „Ukrainian Network Information Center” (UNIC) in coordination with the international system administration on the Internet.

12 Якушев М.В. Есть ли альтернатива интернету? [Електронний ресурс] / М.В. Якушев // Информационное общество. - 2014. - Вып. 2. - С. 4-9. - Режим доступу : http://emag.iis.ru/ arc/infosoc/emag.nsf/BPA/ b1f18e618bded11744257d630043c651.

13 Касенова М.Б. Влияние технологической инфраструктуры интернета на формирование правового регулирования использования интернета / М.Б. Касенова // Право и государство: теория и практика : Научно-практический и информационно-аналитический ежемесячный журнал. - 2014. - № 12. - С. 138. 
It should be noted that the definition of "Internet Governance", developed by a working group under the UN Secretary General, denounced the so-called "approach of all stakeholders," the essence of which is that apart from state governments, international intergovernmental organizations in the management of the Internet takes part so-called „private sector" (commercial organizations, business community and others) and civil society (technical and academic society, experts, etc.) $)^{14}$.

7. The extraterritorial nature of the construction and operation of the Internet requires combination of international and national regulation.

To sum up, the following definition of the Internet as a legal category could be proposed: the Internet is a global publicly available information and telecommunications network with a complex multi infrastructure, which operates on the basis of cross-border management and gives opportunities for creating, posting information and access to it and also for providing related information services. ${ }^{15}$

The object of protection in the web is its content, which means the results of creative activity in various forms that are transmitted throughout the network. Content is information and text that a web-site contains, which is recognized as a copyright object regardless of its content ${ }^{16}$. The main types of copyright results that create the content are works - a set of ideas, arguments, images, scientific statements, estimates, opinions, proposals, etc. that have emerged during creative activity of an author and have been reflected in some objective form ${ }^{17}$. Common to works is that they have arisen as a result of creativity or artistic expression of the author. As it was suggested in the literature, there is a similarity between the concepts of "creativity" and "information”, as they have the same factor and are grounded on the same institutions. Therefore, it is about the emergence of so-called information worldview in which the concept of information takes the central place, and the process of evolution is understood as creative process, the essence of which is the accumulation

14 Касенова М.Б. 2015: перспективы трансграничного управления интернетом / М.Б. Касенова // Евразийский юридический журнал : ежемесячный междунар. науч. и научно-практ. юрид. журнал. - 2013. - № 11. - С. 19.

15 Харитонова О.І., Позова Д. До проблеми визначення правової природи мережі Інтернет // Вісник Південного регіонального центру Національної академії правових наук України. - 2015. - № 4. - С. 79-88.

16 Майданик Н.І. Сайт у мережі Інтернет як невизнаний об'єкт права інтелектуальної власності / Н.І. Майданик // Цивілістичні читання з проблем права інтелектуальної власності, присвячені пам'яті професора О.А. Підопригори 18 квітня 2007 р. : Збірник наукових доповідей та статей. - К., 2008. - С. 182.

17 Сарана С.В. Авторське право та правова охорона інтелектуальної власності в Україні і її адаптація до законодавства Європейського союзу: навчальний посібник - Полтава - 2007 - С. 23. 
of information. ${ }^{18}$ In this context, creativity is the process of searching, processing, production and transfer of information. Thus, the author's work is also information of certain quality. This information is not material, but it is recorded on physical media. Before the spread of digital recording and the Internet, people mainly dealt with the works of science, literature and art fixed on usual media material. With emergence of the web and the possibility of digitizing it is possible to divide all objects of copyright into three groups. The first group includes those works in which the creative result is primarily expressed in the information code and can be recorded on an infinite set of mediums and its various types that actually means that there is no connection to a specific medium and a medium in general. They are literary works, musical works with or without text, audiovisual works, geographical and other maps, plans, etc., phonograms, databases and so on. The second group includes works that are expressed in material things and can't be separated from their physical media. These are works of sculpture, decorative art, architecture, landscape architecture, urban planning and so on. The third group of works consists of those results that were first expressed in the information code, but the author intends in the future to express them in material objects or natural form. These objects are dramatic or dramatic-musical, scenario works, choreographic works, works of architecture, landscape art, etc. in the form of plans, drawings, models and other. The works of the first and third group by there essence are not material things, they do not depend on tangible media and have features of information ${ }^{19}$. The conversion into the information code or into the form of the first two groups objects happens with the help of digitalization technologies, and in this case they hardly lose the content component. The objects of the second group may also be converted into an information system, but during the conversion of material objects of copyright and related rights into the code information opportunities for tactile, taste and other way of their reception can be lost. A communicative component of these objects that is determined by broadcasting features and multiplicativity, on the contrary, considerably increases. This becomes possible due to the transition into an information system, or cyberspace. Today the list of copyright and related rights that are protected include objects designed for visual and aural reception. ${ }^{20}$

18 Будник Р.А. Эволюция системы авторских и смежных прав в информационном обществе: от исключительного к инклюзивному праву автора. - М. : Юрлитинформ, 2013. - С. 19.

19 Будник Р.А. Эволюция системы авторских и смежных прав в информационном обществе: от исключительного к инклюзивному праву автора. - М. : Юрлитинформ, 2013. C. 21-23.

20 Там же. - С. 24. 
Thus, the results of creative activity, with the ability to be digitized, are objects of copyright on the Internet. Under digitization it is understood transfer of any notification into the form of text, audio, static or moving images, binary language that uses binary signs 1 and 0 , which is expressed with the help of electronic. Processing a work by digitizing its objective form does not create a derivative work, because it doesn't have creative features, only technical ones. Digital form allows to store files on physical media, or hard drive, or flash memory, etc. (a file can be stored partly on various media). In this aspect, digital technology has not brought anything new, because the product can be used in any form or in any manner that is not contrary to the law. ${ }^{21}$ But in digital form a work gained new features related to the simplification of reproduction and distribution, placing on the Internet, crossing geographic borders without any verification of copyright at the customs border. Therefore, digitization should be held only with the permission of the author or other copyright subject. In this connection it is necessary to fix in the law an obligation to obtain permission of the author or copyright holder for digitization of the work (transferring it into electronic form) and defining such form of using a work as its digitization.

Analysis of copyright violations on the Internet shows that the most common offences deal with placing works in the network and providing access to them without the author's consent, his successors or other rights holders and also assigning authorship of the works posted on the web. Thus, it is usually about piracy and plagiarism.

Certainly, copyright infringement on the Internet is not limited only to piracy and plagiarism, but these violations cause the most damage to authors, which determines the necessity to find effective means of legal protection during the placement, storage, transportation of copyright objects by using the Internet resources. Thus, it is about protection of the content, the content of the Internet.

Approaches to the problem of copyright protection on the Internet can be summed up in the following way: copyright protection on the Internet has no sense in general; copyright protection on the Internet is not possible with traditional methods of copyright protection; copyright protection on the Internet is necessary and possible by the means of traditional copyright protection. ${ }^{22}$

As to the first approach, it should be noted that its supporters prefer public interest to interests of an author. This is so-called „cyberlibertarianism” -

${ }^{21}$ Орлов Ю. Юридическая оценка творческих произведений в цифровой форме / Ю. Орлов // Право и экономика. - 2012. - № 7. - С.48.

22 Сопілко І.М., Пономаренко О.В. Захист авторських прав в мережі Інтернет монографія. - К. : Компютерпрес, 2013. - С.78. 
a system of social and legal views on the regulation of cyberspace after pronouncing "Declaration of the Independence of Cyberspace” by John Perry Barlow in 1996 in Davos. Cyberlibertarianism is based on the link that the governance of no one country can not be applied to cyberspace; cyberspace has its own unwritten laws, according to which it is developing and operating; social interest has priority. Continuing this trend appeared movement for copyright restrictions (so-called movement „copyleft”), and the idea of free public licenses, whose purpose was to simplify and reduce the cost of permits for using copyright objects and related rights objects.

A free license is a license agreement, the terms of which give a user permission from a copyright owner to use his work in some ways, which give him many advantages. In order to be considered free, a license must permit: use of the work for any purpose, researching it, creating and distributing copies of the work, making changes in the works, publishing and distributing such modified works. The rights listed in the free license usually are granted to any person in the world. Free licenses are usually perpetual (for the duration of copyright), worldwide, non-exclusive and irrevocable.

At the beginning of July 2015 information about an important battle, which had been won by European writers, appeared in periodicals. It was about the revision since 2014 by the European Parliament a Directive 2001 on copyright and related rights in the information society. It should be noted that this measure directly met one of the priorities defined by European Commission head Jean-Claude Juncker: creation on European scale of a "single digital market”. In order to understand the necessity of changes in the mechanism that ensures copyright, regarding large-scale development of digital technologies, analysis of all of its main elements was initiated.

The report on the results of such analysis had to provide MP Julia Reda (representative of the German Pirate Party, whose requirement is free circulation of scientific works and cultural works on the Internet). Finally in the beginning of July, after numerous amendments, the European Parliament approved the etire report, which was characterized by professional organizations and observers as „balanced”. Thus, attempts to limit copyright in Europe have failed. The report is not a statute, but will serve as basis for a new directive, which the European Commission should develop and adopt this autumn ${ }^{23}$.

Supporters of the second approach to copyright protection on the Internet focus on the specifics of the network, which makes it impossible

23 Франкі Бландо. Захистити авторів // Український тиждень. - 2015. - № 35 (407). - С. 47. 
to use traditional methods for copyright protection. On these features of the network (global, extraterritoriality, accessibility, anonymity and interactivity) are also imposed features of copyright objects in a digital format and mechanism of interaction of such objects with the Internet space.

Among the main features of digital technologies, which can affect the properties of the copyright on the Internet, are called: 1) the speed and ease of distribution due to opportunities of the Internet; 2) ease of reproduction and spread of tools to play tracks in digital format; 3) lack of substantial financial costs for the rapid dissemination of copyright; 4) high density of recording media; 5) high qualitative characteristics of digital recording. ${ }^{24}$

Therefore, protection of author's rights on the Internet has its own specifics and copyrights are most vulnerable due to the introduction and spread of digital technology, at least for two reasons. First, most of the information transmitted by the Internet (text, images, sound signals) are works in the legal sense and, therefore, are subject to copyright. Secondly, as the nature of electronic telecommunications itself requires copying data during their transmission channels and viewing them by unlimited range of consumers, certainly, questions regarding respect of copyright during such copying arise. Any online user's behavior affects the rights of authors and their successors. In other words, it is impossible to do something online that would potentially violate someone's copyright. Viewing Web-pages, saving their content in memory, forwarding e-mails - all of these actions include reproducing of the objects that are under copyright law protection. Features of the works published on the Internet as copyright objects are caused by specific form of their fixation. The digital form of fixing these works enables their unique physical qualities and causes significant problems of legal protection ${ }^{25}$.

Art. 15 Civil Code of Ukraine stipulates that everyone has the right to protect their rights in case of violation, denial or contestation, and the right to protect their interest, which is not contrary to general principles of civil law. The main list of ways for protecting subjective civil rights and interests is provided by Art. 16 Civil Code of Ukraine. The court may also protect intellectual property rights and legitimate interests in other civil manner established by the contract or law. This list complements Art. 432 Civil

24 Ієвіня О.В. Правове регулювання розміщення фонограм у мережі Інтернет: проблеми та перспективи / О.В. Ієвіня // Держава і право: Збірник наукових праць. - Випуск 26. - К. : Ін-т держави і права ім. В.М. Корецького НАН України. - 2004. - С. 345.

25 Пастухов О.М. Авторське право у сфері функціонування Всесвітньої інформаційної мережі Інтернет - Автореферат...канд..юрид.наук. - К., 2002. 
Code of Ukraine, according to which the court can make judgment in cases and per the procedure established by the law, namely: applying immediate remedies to prevent violation of intellectual property right and to preserve respective remedies; terminating trespass through the Ukraine custom borders of goods imported or exported with the violation of intellectual property right; withdrawing from civil circulation of goods manufactured or brought into civil circulation under violation of intellectual property right; withdrawing from civil circulation of materials and instruments used mainly to manufacture goods under violation of intellectual property right; applying single monetary penalty instead of reimbursement for losses due to unlawful use of the object of intellectual property right. The amount of the penalty shall be established pursuant to the law taking into account the guilt of a person and other circumstances being of vital importance; publishing in mass media of information about violation of intellectual property right and the contents of court judgment regarding such violation. A special form of protection of intellectual property rights and legal interests is an administrative procedure for protection which is applies in cases specifically provided by the law. According to the law, victims can apply for protection of their violated rights and interests to a state body, the supreme body of the defendant or the Antimonopoly Committee of Ukraine.

However, determining the method and the order of protection the Civil Code of Ukraine even does not mention the global information network Internet, although the latter actually changed the contours of the legal protection of copyright. ${ }^{26}$ The world practice of protection of intellectual property rights, including copyright, shows that there are two main forms of such protection, jurisdictional and non-jurisdictional. Jurisdictional protection involves application for protection to the authorized bodies: court, court of arbitration, etc., empowered to take the necessary measures to remedy and termination offense. Within the jurisdictional form of protection of intellectual property, in turn, the general and special order for protection of violated intellectual property rights is distinguished. The literature draws attention to the fact that courts have very little practice in disputes concerning copyright protection on objects placed on the Internet. This indicates that many of the procedural issues and court, and the author (the plaintiff) will decide for the first time. Among the key issues are: 1) identification of the offender; 2) processing

26 Закорецька Л.О. Окремі питання правової охорони та захисту права інтелектуальної власності за чинним законодавством України / Л.О. Закорецька // Цивілістичні читання 3 проблем права інтелектуальної власності, присвячені пам'яті професора О.А. Підопригори 18 квітня 2007 р. : Збірник наукових доповідей та статей. - К., 2008. - С. 101. 
of evidence; 3) acknowledgment of authorship. ${ }^{27}$ Non-jurisdictional form of intellectual property includes actions of legal entities and individuals to protect intellectual property rights and legal interests taken by their own, without asking for help government or other competent authorities (self-defence rights). According to Art. 19 CC of Ukraine self-defense is the use of individual means of countering that are not prohibited by the law and are not contrary to the moral of the society. Thus, methods of selfdefense must meet the content of the rights that is violated, nature of the actions and the effects caused by this offence. A person whose intellectual property law has been violated can choose, how these methods of selfprotection or self-defense may be established by the agreement.

This refers, of course, only to legitimate means of self-defense, such as refusal to carry out certain actions foreseen by concluded agreement relating transfer of intellectual property rights or by license agreement, refusal to perform the invalid contract and so on. Means of non-jurisdictional copyright protection on the Internet include technical protection means: technological mechanisms (in the form of devices or developments), designed to protect access to and transfer of copyright objects and supplement the legal protection provided by the law and (or) agreement with effective technical protection. ${ }^{28}$ Art. 1 of the Law of Ukraine „On Copyright and Related Rights" includes the definition of technological protection measures as technical devices and (or) technological developments designed to create a technological obstacle to the infringement of copyright and (or) related rights during the perception and (or) copying protected (encrypted) recordings in phonograms (videograms) and broadcasts of broadcasting organizations or to control access to the use of copyright and (or) related rights.

In conclusion, it should be emphasized that the specific copyright protection on the Internet is a combination of different forms of protection using technical means and establishing responsibility for their overcoming as well as for manufacturing and distributing devices designed to overcome technical means of protection of copyright on the Internet.

27 Бойченко А. Захист авторського права і суміжних прав і Інтернеті / А. Бойченко // Інтелектуальна власність. - 2012. - № 6. - С. 42.

28 Право інтелектуальної власності: посібник / за ред.. Р.Б. Шишки (кер.авт.кол.) та інш. К. : „МП Леся", 2014. - С. 163. 


\section{USING THE CONCEPT OF „LOOK AND FEEL” FOR THE PROTECTION THE WEB SITES AS THE OBJECTS OF INTELLECTUAL PROPERTY RIGHTS}

Information technologies are gaining more momentum every day in Ukraine and worldwide. Information space becomes an arena of social and economic development. Unfortunately, the law which should govern such relationships are often behind in their development, so in practice there is a large group of outstanding relationship that leads to legal uncertainty and disputes. The complexity of the interface protection website is that, at this time, the website development software has a limited number of teams, and thus no way to protect the external expression of the website.

IT-law - is a new phenomenon in civil law in Ukraine, which is only in their infancy, but considering all formed social relations in society in this area definitely requires considerable attention and further development. Among the Ukrainian scientists, who are involved in the development of IT-law, should be called O.A. Baranov, K.I. Belyakov, V.M. Brizhka, R.A. Kalyuzhnyy, L.P. Kovalenko, B.A. Kormich, V.A. Lipkan, A.I. Maruschak, A.M. Nowickii, V.G. Pylypchuk, O.M. Seleznev etc.

In the most general terms, under the IT-law means a series of rules and regulations that mediateefforts to ensure security of information technologies and information activities on the Internet. IT-law is characterized as a multidisciplinary branch of law, which combines the above civil, commercial and administrative area.

The concept of „look and feel" - is part of a more general concept - „Trade dress", which is a new way to protect copyright on the Internet. "Trade dress" emerged and became widespread in the US in the 90-ies of the twentieth century. Then, this concept was taken over by many European countries such as Britain, Switzerland, France.

"Trade dress" - is a common expression of the product, which may include characteristics such as size, shape, color or color combinations, texture, graphics, etc. that distinguish goods and products from other goods and identify the origin of goods is from a particular manufacturer, and not associating it with specific functionality. ${ }^{1}$ Today certain requirements have already been formed, features that are characteristic of the concept of trade dress.

1 What's inherently distinctive? Duraco Products Inc. v. Joy Plastic Enterprises Ltd., 40 F.3d 1431 (3d Cir. 1994) [Electronic resource] / Rich Stim // Nolo. - 2017. - Access mode:: http://www.nolo.com/legal-encyclopedia 
The first requirement is trade dress has to be no functional. Functionality determines that trade dress product packaging, outer expression of intellectual property object serves for the purpose it was created. For example, a bottle of Coca-Cola has its own unique shape, but the shape is not a prerequisite to perform its function: a bottle for fluid storage.

The second requirement - is a distinctive feature. Trade dress products or goods need to be different from other products and goods, it should be unique and differentiate this intellectual property among others.

Finally, the last requirement - is the standard required for the registration of trade dress. Registration requirements of trade dress similar to the requirements that apply to logos and brands. It is necessary to conduct detailed trade dress object of intellectual property except for the use of the exceptional characteristics of the goods or product competitors for commercial gain. But looking at the practice of most American and European courts, trade dress is perceived and protected by the court and without the appropriate registration by a public institution. So, we can say that this condition is optional, not necessary, but desirable.

"Trade dress" concept stands out among other ways of protecting intellectual property rights due to wide scope of intellectual property and the intuitive perception of the public, consumer product related with this external expression of the respective manufacturer. In certain situations, trade dress could be a successful means for protecting a Web site's visual design or look and feel. It is clear that trade dress protection is not an absolute solution to the problem of protecting the total look and feel of a Web site user interface from being copied or exploited without permission.

Since Web sites are often changed and modified, it may be difficult for a descriptive trade dress to ever acquire secondary meaning such that it would be afforded trademark protection. The best situation for a descriptive trade dress would be an elaborate trade dress that is already used in other advertising materials for the product or company, so that its use is already established when used on the Web site. In this case, there would be a better chance that the requisite level of secondary meaning could be shown in order for distinctiveness to attach the descriptive trade dress. Since it is crucial to find that there has been sufficient consumer exposure to a particular trade dress in order to have secondary meaning, a court may consider the following factors:

1. The duration and exclusivity of the design's use;

2. The amount and nature of advertising that emphasizes the design and its distinctive, identifying features;

3. Consumer survey evidence linking the design to a single source; 
4. The defendant's intent in copying the design².

These factors for finding secondary meaning could be problematic when applied to Web site user interfaces. The duration and exclusivity of all elements in use of a Web site user interface design may not be very lengthy, due to frequent changes and updates. Second, a Web site can often be a primary source of advertising itself, so there may not be many other materials beyond the Web site that reflect the trade dress of a business. Further, the trade dress presented in a Web site may be in keeping with the image of a particular business, but not reflect the exact trade dress used in other advertising for the business. So, protection of the trade dress contained in the Web site interface may not be easily gained if secondary meaning is required. Next, consumer survey evidence can be costly and inaccurate. It is hard to tell how many people are even using the Internet much less how many people made associations to a particular source after viewing a Web site.

A legal theory for protecting the overall design and concept of a Web site user interface, i.e. the "look and feel" of the interface. As explained by David Bender, the „look and feel” refers to the user interface, generally manifested by the display screens that a computer program generates and the keystroke combinations that are used for particular program functions ${ }^{3}$. The concept of "look and feel” was formed gradually through computer games. For the first time there was such thing as "look”, in 1976. The prominent case Atari, Inc. v. North American Philips Consumer Electronics Corp. helps support the argument that a screen display in a user interface may be extended copyright protection as an audiovisual work ${ }^{4}$. To analyze the substantial similarity of the screens, the Seventh Circuit considered the similarities of the game characters in both computer games ${ }^{5}$. Defendants used K.C. Munchkin "gobblers" and "ghost monsters" which were similar in both appearance and concept to Atari's „Pac-Man”. Even though there was not exact copying of the screen displays by the Defendant, the court found that Defendant's game captured the total concept and „feel" of Atari's

\footnotetext{
2 Duraco Prods., Inc. v. Joy Plastic Enters., Ltd., 40 F.3d 1431, 1452 (3d Cir. 1994) [Electronic resource] /United States Supreme Court Cases//- 23.04.2017. - Access mode: http://digitalcommons.law.scu.edu

3 David Bender \& Craig Nethercott, Lotus v. Borland: At the United States Supreme Court, 430 PRAC. L. INST. 7, n.1 (1996).

4 Atari, Inc. v. North Am. Philips Consumer Elecs. Corp., 652 F.2d 607 (7th Cir. 1982). [Electronic resource] United States Supreme Court Cases//- 29.04.2017. - Access mode: http://digitalcommons.law.scu.edu

5 Id. at 6012.

6 Id. at 611.
} 
game$^{7}$. This case opened the door for protection of the overall presentation and "feel" of video game screen displays, but the Seventh Circuit court did not address how far this theory of copyright protection should be extended.

Soon after this case, registering the „look and feel” of all computer programs became routine 8 . The Copyright office allowed registration of visual displays either as separate audiovisual works or as separate literary works ${ }^{9}$. Subsequently, the Office decided to allow registration of an underlying computer program to extend to all the elements of the audiovisual screen display that the program generated ${ }^{10}$. In 1988, the Office adopted internal guidelines to support single registration for all aspects of computer programs, including the visual screen displays ${ }^{11}$. However, it is still unclear exactly what subject matter is covered in the copyright protection of computer programs. Thus, enforcing a single registration for all aspects of the computer program in court is unpredictable. While each case must be examined separately on its facts, making the extraction of guidelines from case law is difficult. The existing copyright laws are more readily applicable to individual graphic elements in a screen display or user interface, but it is hard to tell how far copyright protection will extend beyond source and object code and if it will adequately protect the entire look and feel of computer user interfaces ${ }^{12}$. This concept concerns the appearance of the video game and its visual perception.

Then added the term "feel", concerned that provisions in the interface buttons. In other words a sequence of buttons on your user's screen. ${ }^{13}$

In modern conditions, the trade and services in the Internet space began to develop rapidly. In this regard, legal entities and entrepreneurs began to invest their capital in developing and improving their websites to be not only easy to use but distinguishable as the site of one particular company. A consumer visiting a particular site must use some imagination to understand the whole scheme of how the site looks in order for the trade dress to be considered suggestive. But, if mere observation only tells the consumer some descriptions about the product in a basic sense,

\footnotetext{
7 Id. at 619-620.

8 Russo \& Nafziger, supra note 3, at 575. [Electronic resource] United States Supreme Court Cases// - 22.04.2017. - Access mode: http://caselaw.findlaw.com

9 Id. at 576 .

10 Id. at 576.

1136 Pat. Trademark \& Copyright J. (BNA) 152-155 (1988).

12 Russo \& Nafziger, supra note 3, at 577. [Electronic resource] United States Supreme Court Cases// - 22.04.2017. - Access mode: http://caselaw.findlaw.com

13 Atari, Inc. v. North Am. Philips Consumer Elecs. Corp., 652 F.2d 607-614 (7th Cir. 1982). [Електронний ресурс] - 28.04.2017. - Режим доступу: http://digitalcommons.law.scu.edu.
} 
then there is arguably not a suggestive trade dress. The consumer must identify with some source when he views the Web site. It is more feasible that a consumer would see the graphic presentation on the screen and perceive some „suggestion" about the source, rather than some arbitrary or fanciful association. Again, it would be difficult to show that seeing the creative buttons or commands for navigating the information caused some identification with the source. Many Web sites may have similar buttons. The only way to protect the buttons and the graphic presentation together would be to show that they are so unique or dependent on each other for the overall look and feel of the interface that they could not be separated out of the total trade dress impression. This may be difficult to prove because similar command hierarchies for navigating a Web site are used on the Internet. The command hierarchy would have to be elaborate and creative, so when it was considered with the totality of the interface the appropriate level of distinctiveness could be found in the look and feel of the interface. But how an entrepreneur can protect their contributions to their website from unfair competition in the Internet space?

Protecting an individual element contained in a Web site page, like a registered trademark or picture protected by copyright, is not this comment's main focus. Instead, this comment discusses how to legally protect the scheme, design, or total layout of individual elements in a particular Web site user interface. When a business hangs out its shingle on the Internet, the Web site user interface is the shingle. A computer program that is comprised of sequential commands assists in the generation of the interface that allows the user to interact with the program. With an estimated thirty million users on the Internet, Web site user interfaces are valuable as marketing and advertising tools for selling products and promoting businesses on the Internet ${ }^{14}$. This interface is the first impression a consumer has contact with on the Internet, so its presentation is vital for commercial selling purposes. Some designers of computer programs even consider the user interface, which is the visual, external expression of their creativity, to be the most important element of the program. Thus, the entire Web site user interface is valuable intellectual property and worthy of legal protection.

This comment focuses on Web sites found on the World Wide Web component of the Internet because it is the portion most widely used by the public for selling goods and services ${ }^{15}$. The World Wide Web is

14 PEOPLEBANK: Net Yourself a Job!, M2 PRESSWIRE, Feb. 13, 1996; World Wide Web Could Be Threat to On-Line Services, MILWAUKEE J. \& SENTINEL, Feb. 26, 1996, at 9.

15 The World Wide Web network of computers, which is part of the Internet, is built on hypertext technology. Robert Atkins, The Art World \& I Go On Line, ART IN AMERICA, Dec. 1, 1995 , at 58. 
now a commercial entity, not just a means for obtaining or transferring information $^{16}$. For instance, it is difficult to watch television without seeing Web sites posted in commercials so consumers can obtain further information about products on the Internet. Thus, Web site user interfaces are a valuable advertising tool and means for presenting products or services to potential consumers in cyberspace.

The Web site is an electronic communication ${ }^{17}$. This communication is generated with the assistance of a computer program that is structurally similar to software applications used to organize one's business or play video games, i.e. the software programs involved make requests to the operating system of a computer so the visual user interface will be displayed to the user. But on the Internet, the end visual presentation a user sees on the computer screen will be used to attract potential consumers to the Web site. Setting up a Web site can provide many commercial benefits for a business. For instance, among its many commercial benefits, a Web site can identify one's business or products and be used as an advertising tool. These benefits can help a business gain a competitive advantage in the marketplace. Therefore, the user interface, which helps grab a user's attention and helps the user easily navigate the site, is the most important component of the Web site.

In addition, it is important to understand that Web site user interfaces on the Internet are a different kind of electronic environment than user interfaces in a video game or in application software because there is not a uniform regulatory entity controlling the Internet ${ }^{18}$. It is not like states that have boundaries, whereby interstate commerce is regulated by the federal government according to one unifying law of the land. The Internet is so vast and difficult to define that even if a central governing body existed, enforcing uniform rules would be difficult. Most people using the Internet would likely object to strict regulatory confines or rules. Many cyberspace participants want to perpetuate a free flow of ideas and share information even if it violates the intellectual property rights of another ${ }^{19}$. Although it creates many problems and leaves other problems unresolved, state and federal courts must apply existing laws to this new medium, as a means of controlling the Internet environment.

\footnotetext{
${ }_{16}$ Greg R. Notess, The Internet Goes Commercial, DATABASE, Vol. 18, No. 6, Dec. 1995.

17 Jonathan Freedland, The Writing on the Toilet Wall, THE GUARDIAN (London), Feb. 14, 1995, at 18 .

18 John P. Barlow, Crime and Puzzlement: In Advance of the Law on the Electronic Frontier, WHOLE EARTH REV., Sept. 22, 1990, at 44.

19 Eric Schlachter, The Intellectual Property Renaissance in Cyberspace: Wfhy Copyright Could be Unimportant on the Internet, 12 BERKELEY TECH L.J. 15 at 34.
} 
There are many other problems created by the Internet that affect the legal protection of intellectual property contained in a Web site.

First, the marginal costs to distribute and copy information on the Internet are less than costs to physically distribute the information or purchase a copy ${ }^{20}$. The Internet is an international, interconnection of computer networks that links millions of Internet users together and permits them to access and share information at a low cost.

Secondly, some users believe that copying the layout of a competitor's site is not wrong, but merely a practical utilization of information readily available in cyberspace. What some call wrongful stealing, other Internet users would call smart business tactics. For example, riding the coat tails of a competing product's strength in the market by confusing the public is a somewhat efficient business tactic, but a tactic not allowed under trademark law.

Thirdly, the boundaries of the Internet are difficult to ascertain. Consequently, traditional notions of jurisdiction for courts are severely challenged because pinpointing where something is located in cyberspace is nearly impossible ${ }^{21}$. Currently, jurisdiction, venue, and the choice of law for any particular case is uncertain.

Finally, the exact identity of Internet users is often difficult to establish, so even pinpointing potential wrongdoers on the Internet can be extremely difficult ${ }^{22}$. The need for look and feel protection will likely continue to expand in the near future and into the next century due to the consumer market demand for more creative and complex interactive interfaces.

Also, businesses will have to use very creative means to catch and hold a consumer's attention on the Internet. In addition to this, commercial usage of the Internet is vital for any business or entrepreneur who wants to successfully compete in today's markets because our society is becoming more dependent on the Intemet for communication and conducting business. Finally, as the Internet becomes more commercialized, businesses will want assurances that valuable intellectual property contained in Web sites will be protected, thereby reducing the risks of doing business on the Intemet.

It is already apparent that applying existing laws to the Internet will present a challenge to lawyers and courts.

20 Jack Russo \& Jamie Naftiger, Software "Look and Feel" Protection in the 1990s, 15 HASTINGS COMM. \& ENT. L.J. 573 (1993).

21 Richard Raysman \& Peter Brown, On-Line Legallssues, N.Y..., Feb. 15, 1995, at 30.

22 Greg R. Notess, The Internet Goes Commercial, DATABASE, Vol. 18, No. 6, Dec. 1995. 
The first high-profile case which gave rise to protect web sites on the Internet, was the case-Apple Computer, Inc. against Microsoft Corporation. ${ }^{23}$ The following case provide insights into the analysis a court would likely follow to determine copyright protection of a computer user interface. It is logical that this reasoning could apply to Web site user interfaces on the Internet because they serve the same purpose as computer user interfaces. Both interfaces allow a user to interact with the presentation displayed on the screen.

The graphical interface included overlapping windows, iconic representation, object opening/closing, menus and iconic manipulation. The case involved complex issues about licensing agreements, whereby Apple granted Microsoft a limited license to use its visual displays in Microsoft's software, and in turn Microsoft licensed these visual displays to a third party, Hewlett Packard ${ }^{24}$. So, the court ruled against Apple on many of its copyright claims, due to the licensing agreement ${ }^{25}$. But, the main value of the case to this comment is the manner in which the court reasoned the proper scope of copyright protection of graphical user interfaces.

Despite the fact that there has been denied copyright protection for the entire interface, in the judgment of the District Court was formulated many aspects that should be considered creators and site owners in protecting their copyright. Thus the Court has formulated the procedure for determining violations of intellectual property rights on the websites. Web sites are compared in two dimensions. The first dimension - is the appearance of the interface (which is also called „objective standard") and, if the court finds on the similarities, the court proceeds to the second stage. The second - a comparison of the position of the various functional buttons on the user (which is also called "subjective standard"). Originality - is to find that a work is original, there must be some independent creation by the author, and some minimal degree of creativity.

The intrinsic test is limited to comparing only those elements of a work that can be the subject of copyright, so this prong is not considering the work as a whole, but instead comparing the work's individual components. One problem for Apple was that analytic dissection was used under part one of the test to filter out which elements were protect able in the interface ${ }^{26}$. Then,

${ }^{23}$ Apple Computer, Inc. v. Microsoft Corp., 799 F.Supp. 1006 (N.D. Cal. 1992), afd, 35 F.3d 1435 (9th Cir. 1994 [Electronic resource] United States Supreme Court Cases// - 01.54.2017. - Access mode: http://digitalcommons.law.scu.edu

24 Apple Computer, Inc. v. Microsoft Corp., 799 F. Supp at 1016, 1015. [Electronic resource] United States Supreme Court Cases// - 30.04.2017. - Access mode: http://caselaw.findlaw.com

25 Id. at 1016.

26 Id. at 1020. 
only protectable features were compared for similarities ${ }^{27}$. This dissection approach means that if the similarities found between two original works stem from features in the graphical interface that are individually not protectable by copyright, the court will not even get to step two of the test for infringement ${ }^{28}$. This clearly leaves the copyright protection available for a Web site user interface diminished because many elements in the interface will not be considered copyrightable subject matter individually, even though they contribute to the look and feel of the interface. Apple argued that the court should consider the entire look and feel of the graphical interfaces, regardless of the protection allowed for each individual element of the visual display ${ }^{29}$. However, the court clearly discounted this line of reasoning by employing the two-step test, which filtered out unprotectable elements before similarities between the two works were even considered ${ }^{30}$. This dissection process defines the scope of the plaintiff's copyright, such that the „intrinsic" step of the test is not even needed if there are no protectable elements to compare ${ }^{31}$. When filtering out elements, or dissecting the work, to identify the protectable features of a plaintiff's work, the court looked at doctrines used to decipher the line between an idea and expression ${ }^{32}$. For example, Apple could protect the expression or particular manner in which it displayed the garbage can icon for deleted materials, but not the general idea of using a waste receptacle for deleted material ${ }^{33}$. It is clear from the case that only expressions are protected and ideas that merge with expression only get copyright protection from identical copying ${ }^{34}$. Although some elements in a graphical interface may be set aside and only granted protection from identical copying, this is actually a limited form of copyright protection. So, certain expressions that do not qualify individually for copyright protection will be unprotected in an interface, even if taken together with individually protected elements these expressions could actually qualify for copy right

27 Id. at 1021.

28 Id. at 1022. See also Feist Publications, Inc. v. Rural Tel. Serv. Co., 499 U.S. 340 (1991).

29 Apple Computer, Inc. v. Microsoft Corp., 799 F. Supp at 1006, 1016. [Electronic resource] United States Supreme Court Cases// - 01.05.2017. - Access mode: http://caselaw.findlaw.com

30 Id. at 1021.

31 Id. at 1021.; see also Brown Bag v. Symantec, 960 F.2d. 1465, 1475-76 (9th Cir. 1992). [Electronic resource] United States Supreme Court Cases// - 30.04.2017. - Access mode: http://caselaw.findlaw.com

32 Id. at 1021.

33 Id. at 1035-1036.

34 Id. at 1021. But see also Sid \& Marty Krofft Television v. McDonald's Corp., 562 F.2d 1157 (9th Cir. 1977). [Electronic resource] United States Supreme Court Cases// - 29.04.2017. - Access mode: http://caselaw.findlaw.com 
protection. For example, if an element is found to be lacking originality or is functional, it would not be included in determining the total expression to be protected in an interface. Dissection clearly hurts any overall copyright protection that might be available for the graphical interface and likewise a Web site user interface. While Apple lost on many claims of similarities between its graphical interfaces and Microsoft's interfaces, it is important to notice that this outcome could be the result of asserting the wrong cause of action. Many arguments made by Apple to persuade the court to grant copyright protection of all the elements contained in the interface as a whole were actually trademark arguments. Apple argued that „to understand the distinctive appearance of the Macintosh interface, one needs to consider not only the individual elements that make up the appearance of the interface but also the way those elements are arranged and interact with one another to create the consistent and distinctive Macintosh interface" ${ }^{\prime 35}$. This basic argument could fit under a trade dress theory because the references to "distinctive appearance" and the arrangement of elements in the interface sound like references to trademark law.

The court reasoned that the „look and feel” of Apple's interface was actually just a „collection of visual displays and user commands designed to render use of the computer". Apple's claims may have been more successful under a trade dress theory. It is likely that many elements in a Web site interface could be viewed as functional and only needed to operate the site. These functional elements will be dissected out of the whole „look and feel" of the interface when copyright protection is considered.

The second thing which you needs to pay attention - the case of Lotus Development Corp. against Borland International, Inc. ${ }^{36}$ The case could cause the protection of an interface's total look and feel to be diminished in the future.

The concerns over program function compatibility and writing macros for the simplicity of operation, which were present in Borland, are not issues when protecting Web site interfaces. It made sense in Borland that forcing a user of several different computer programs to learn all the different ways to operate similar functions in each program was not practical ${ }^{37}$. But, in cyberspace, many Web sites are visually set up differently, operate in

35 Id. at 1022.

36 See Robert L. Bocehino, Jr., Note, Computers, Copyrights and Functionality: The First Circuit's Decision in Lotus Development Corp. v. Borland Int'l, Inc., 9 HARV. J.L. \& TECH. [Електронний ресурс] - 15.04.2017 - с. 467- Режим доступу: http://digitalcommons.law.scu.edu

3717 U.S.C. § 102(a)-(b) (1994); See also, HOWARD C. ANAWALT AND ELIZABET F. ENAYATI, IP STRATEGY: COMPLETE INTELLECTUAL PROPERTY PLANNING, ACCESS AND PROTECTION § 1.03[1], [9] (1997). 
different ways and are used to represent different entities and products. Other sites collect and present information from many individual entities, so they do not need to have functioning mechanisms that are similar to other Web sites. Thus, the policy considerations so heavily relied upon in Borland may not be as relevant when considering the copyright protection of the keystroke commands or icons in Web site interfaces, either as individual protectable elements or as the entire „look and feel” of the interface. Arguably, some buttons used to operate command aspects of a Web site user interface may be compatible with other sites because the software used to create Web sites only allows a limited number of choices. In addition, most Internet users want some standardization and compatibility between commands for convenience. These arguments could add fuel to the position that the „look and feel” of Web site interfaces should not be copyrightable, but it is unclear how much weight a court would give these arguments. Standardization and compatibility would perpetuate convenience for the Internet, but they are not necessary for it to function as a marketplace for goods and services. Also, future innovations will likely create an infinite number of options for generating buttons, icons, or visuals on a Web site. But, this kind of copyright protection would only protect some aspects of a Web site user interface and not the presentation in its entirety, i.e., its „look and feel”. This overall concept and impression represents the business image generated in consumers' minds which affects their buying decisions. It is the overall impression and complete layout or organization that is so valuable to a Web site owner and gives the owner a competitive advantage in the marketplace because it grabs the attention of consumers and helps build brand recognition. This overall impression or "look and feel” carries out a consistent theme, so a Web site can stand out among the massive volume of Web sites out there.

The decision in this case the US Supreme Court ruled, and this decision was not to support the concept of "look and feel". The main question that the court decided was whether there is a sequence of commands at the subject of copyright protection. Having reviewed the case, the US Supreme Court concluded that if the command set is unique, it can be protected as an object of intellectual property rights. But also, the court noted, that it was creative, copyright registration of teams is their external expression is not important for protection. The only important functional component command set. Proclaiming the decision in this case the court was guided by the laws of copyright.

However, the case pointed out that if the expressive aspects of the screen displays were not needed to operate the computer program, they would 
not necessarily be deemed unprotectable methods of operation. Thus, the separate protection of the visual screen display in a Web site interface is not necessarily affected by the court's decision in Borland.

There are many ways to create a visual display through computer graphics and an infinite number of graphical elements that an owner could include in a Web site user interface. So, a creative graphic screen display could satisfy the arbitrary requirement provided it was so unique that other sites would not necessarily possess the same look and feel. However, the command or icon elements for navigating the information could be considered commonplace in many other sites. The limited ways of presenting the buttons used for moving about the site could present a problem with finding the whole site distinctive because the buttons might be considered a standard or merely functional. If the command buttons used to navigate the sight are simple and standard, a court may just protect the visual graphics in the screen display without including the buttons, even if the buttons are labeled creatively or have animation.

In addition to this, the creative labels used on a Web site to jump to another screen or activate a hyperlink might get copyright protection if the labels could be designed without solely being an operation.

Unfortunately, this would be a difficult argument to advance because the only way to navigate a Web site is by „pushing” the buttons, like in the court's analogy to VCR buttons. Thus, it is difficult to predict how a court will rule on the copyright protection of the command elements contained in a Web site user interface's „look and feel”.

Unfortunately, in a US District Court decision in the case BlueNile, Inc. Against Ice.com, Inc. 478 F (W.D. Wash. 2007) was described statement that „the appearance" of the web site may not be protected under the provisions of "Trade dress", and the concept of "look and feel”, as its components. In this case, the plaintiff and the defendant were direct competitors in the Internet space for the sale of goods such as jewelry. Ice.com copied significant portion of website elements Blue Nile, what caused Blue Nile, Inc. significant losses. The defendant contended that the provisions of "Trade dress" and provisions of trademarks does not apply to websites. The court in its ruling said that at present it is not possible to determine whether the site belongs to intellectual property rights and whether it can be protected by the relevant laws and the concept of "look and feel”.

In support of this statement was the decision of another court case in the US Darden v. Peters, 402 F. (E.D.N.C. 2009), where the court finds it impossible copyright registration of the website in exactly the same procedure as trademarks. 
So, as we can see, the problem that has developed - is a controversial practice regarding the possibility of protecting intellectual property rights to the interfaces of websites.

It is apparent that „look and feel” protection will fall short of completely protecting a Web site owner from someone else using his creative Web site interface look and feel. First, it may be difficult to find sufficient originality in a Web site interface for copyright protection if the Web sitemerely presents and organizes facts. Second, many individual elements in a user interface may be left unprotected after subject matter is dissected by the substantial similarity analysis for infringement, as seen in Apple. Third, individual elements or the entire Web site may be deemed a method of operation or fall under other exceptions which exclude copyright protection of certain types of subject matter, as seen in Borland. Finally, even if some copyright protection is afforded, it may not be for the entire „look and feel” of the Web site, and it is this total presentation that is so valuable for marketing purposes in cyberspace.

Applying the concept of „look and feel” for copyright matters in the sense that it helps to determine the degree of similarity in divergence interface similar websites and conclude whether copyright infringement or not. That is why there is need to develop appropriate legal regulation of these issues in Ukraine. 


\section{MEDICAL SERVICES AND INFORMATION TECHNOLOGY}

Nowadays health protection is one of the leading fields that provide services. Art. 49 of the Constitution of Ukraine establishes the right of everyone to health protection and medical care, the contents of which, in particular, is entitled to medical services ${ }^{1}$. At the same time to define the essence of health services is of high priority, since the general level of satisfaction with the quality of life in our society depends on how effective these services are.

The concept "medical service" appeared in the legislation of Ukraine in the early 90 s of the last century, however up to now this concept has been used much less frequently in most acts of current legislation than the concept „medical care”2.

The decision № 15-rp/98 dated November 25, 1998 of the Constitutional Court of Ukraine (on charged medical services) states that the concept „medical care" is not interpreted by the Constitution of Ukraine. Neither Principles of Health Legislation nor other regulatory acts define the concept. However, the concept "medical care” in medical science comprises mainly treatment, prevention measures, that are applied during illness, injury, childbirth, and also medical examination and some other types of medical activity. The concept „medical service” which is close in meaning to the term „medical care" still remains undetermined not only in regulatory acts but also in medical literature. Thus, the Constitutional Court of Ukraine notes the lack of the definition of the concept „medical service”. Unfortunately, this issue is still not resolved at the regulatory level.

S. Antonov's point of view concerning the essence of services is convincing. Thus, medical service is a kind of professional or business activity of medical institutions (organizations), individual entrepreneurs engaged in private legal practice, which includes the use of special measures in relation to health (resulting in the improvement of the general state of functioning of some organs or systems of human body) or aimed at achieving certain aesthetic appearance changes ${ }^{4}$.

\footnotetext{
1 Конституція України : Закон України від 28 червня 1996 р. № 254к/96-ВР // Відомості Верховної Ради України. - 1996. - № 30. - Ст. 141.

2 Антонов С. В. Правова регламентація надання медичних послуг // Управління закладом охорони здоров'я. - К., 2007. - С.18-22.

3 Рішення Конституційного Суду України у справі за конституційним поданням 51 народного депутата України щодо відповідності Конституції України (конституційності) положень статей 24, 58, 59, 60, 93, 1901 Кримінального кодексу України від 25 грудня 1998 року № 1-29/98. - Режим доступу : http://zakon2.rada.gov.ua/laws/show/v015p710-98

4 Антонов С.В. Договір про надання платних медичних послуг: від укладення до виконання // Управління закладом охорони здоров'я. - 2007. - № 3. - С. 18.
} 
Some scientists determine medical service as a technological process, which goes beyond medical care and is provided on payment basis on the request of a private person (Hizheskyy V.K., Holovchenko V.V., Kovalsky V.S.) ${ }^{5}$.

From S.S. Shevchuk's point of view medical service is one of the varieties of services, the application scope of which involves social relations; based on these relations citizens in order to meet their specific needs (which in its turn are determined by people's state of health) receive special consumer value through specialized medical professional organizations or an expert in the field of medicine. He also indicates that medical service is an economic and legal category. Such service has a definite cost, the monetary value it represents. It includes the costs of production of a service, its costs and the profit (financial interest of producer's services), that covers the expenses of production in order the corresponding activities to be profitable. Thus, the cost of medical services includes needs, which justify the cost and the possibilities of investment payback at the expense of an obtained profit. Therefore, medical service is always payable for its producer, except for providing such services to a certain citizen free of charge ${ }^{6}$.

Medical service is also suggested to be determined as a service provider's activity aimed at achieving the result, beneficial properties of which can satisfy the needs of an individual in reconstruction and (or) maintaining their health, directly in the process of the service provider's undertaking expedient activity that does not have materialized expression (physical form) and cannot be guaranteed by a service provider ${ }^{7}$.

As a rule, the criteria to distinguish the concepts "medical care” and "medical service" include a place of providing services and financing the mechanism of payment for their provision. According to art. 49, ch. 3 of the Constitution of Ukraine state and communal health protection institutions provide medical care free of charge. Accordingly, medical services are usually provided for a fee by the subjects of private medical practice. In $\mathrm{N}$. Gaidai's strong opinion another criterion for providing either a medical care or a medical service can be patient's state of health ${ }^{8}$. However, these distinguishing criteria are rather conventional because the emergency

5 Прасов О. О. Право на медичну допомогу та його зміст // Сучасне українське медичне право : моногр. - за заг. ред. С. Г. Стеценка. - К.: Атіка, 2010. - С. 74.

6 Шевчук С.С. Правовое регулирование возмездного оказания медицинских услуг: реалии и перспективы. - Ставрополь : Сев-Кав. ГТУ ; Ставропольсервис школа, 2001. C. $77-78$.

7 Чехун О В. Надання платних медичних послуг : цивільно-правові аспекти // Часопис Київського університету права. - 2010. - № 2. - С. 214.

8 Гайдай Н. Правове регулювання та особливості договорів про надання медичних послуг // Юридичний журнал. - 2010. - № 10. - С. 55-58. 
services that will be provided in a private clinic can also be considered as medical care. However, the state in which the patient can be provided with medical assistance is alsobelieved to be an ambiguous criterion.

S.V. Antonov refers aim (final outcome) to the distinguishing data criteria. The purpose of a medical institution activity when an individual applies for treatment is the improvement of human health and its result is the lack of symptoms of the disease (recovery). In case a healthy person who just wants to improve some features of appearance applies to a medical institution, medical intervention will result in the aesthetic changes. Thus, medical services can bring about not only the healing (recovery) result, but also additional aesthetic effect. Medical assistance is always aimed at achieving a therapeutic, diagnostic or prophylactic result. The author notes that medical aid can be provided within medical service that is why medical assistance can be a part of medical service.

The opposite view is expressed by O. Bedenko-Zvarydchuk who also tried to differentiate the concepts "medical service" and "medical care” in her works. In particular, medical services are defined as a kind of relationships related to medical aid and regulated by the contract for the provision of medical services. In this regard medical service is one of the components of medical care. It is not identical with medical care because medical care is wider in its meaning 9 .

Along with that, special properties of medical service are as follows: it is intangible and cannot be stored, it cannot be separated from the source, it is not constant in quality, it does not have a clear commodity form and consumer properties.

However, "medical care” and „medical service” in legal sense can be distinguished according to law regulation. Thus, medical care is regulated by public law while medical services are defined by private law ${ }^{10}$.

In fact, having economic content medical services take the form of property relations, and therefore are regulated by civil law. The principles of such regulation include freedom of expression and legal equality of the parties. In the case of payments for service delivery a patient and a physician (a medical institution) enter into a contract to perform certain actions. Implementing this contract a patient meets his moral interest while a physician (a medical institution) satisfies a property one. If a state or a municipal institution is a party delivering this service, a patient all the same

9 Булеца С. Б. Цивільні правовідносини, що виникають у сфері здійснення медичної діяльності: теоретичні та практичні проблеми : автореф. дис. ... д-ра юрид. наук : 12.00.03. Одеса, 2016. - С. 26.

10 Гайдай Н. Правове регулювання та особливості договорів про надання медичних послуг // Юридичний журнал. - 2010. - № 10. - С. 57. 
meets his moral interest. An institution performs its functions by providing services. However, in the first and in the second case, the service has the same content and results. Thus, the state (municipal) institution performs its function by providing a free service, but the service does not cease to be a service and it is not converted into medical care ${ }^{11}$.

The research allows to define the concept of medical service as a professional activity of medical institutions (organizations) or individual entrepreneurs who are engaged in private medical practice based on current medical standards which in its turn include medical intervention as a special health measure which potentially results in improving the general health or functioning of individual organs or systems of the human body and (or) in achieving certain aesthetic changes in the appearance.

Among the characteristic features of health services the following ones should also be noted:

1) the ability to meet the need of an individual in medical care in order to protect and strengthen their health;

2) uncertainty of the necessity of a medical service because this or that medical treatment is necessary in case of poor health and a consumer is unable to find out in advance when and to what extent he will need medical services;

3) time duration of a medical service. In general, various medical services cover the entire human life, so medical professionals of different profiles provide these services at different times. It is also necessary to note that there is no clear understanding of the time result in each case, the necessity of additional examination and the time period between the end of the service and the expected result may be quite long;

4) individuality, instability and subjective assessment of quality. The quality of medical services is based on the combination and coordination of patients' expectations from the estimation of their real consumption, therefore service quality assessment is quite subjective. In addition, one should take into account that one and the same medical service can affect people differently;

5) integrated medical services as services in the field of health protection are often characterized by the complexity of their structure as they comprise several "basic” services and result from work activity of several medical workers;

6) their aim is an influence on a patient's health which is always of nonphysical character, but necessarily provokes physical changes in a person's body;

11 Венедіктова І. В. Правова природа медичних послуг // Наукові записки Інституту законодавства Верховної Ради України. - 2014. - № 5. - С. 46. 
7) their public character and the possibility to be provided to all people who apply for them;

8) cannot be subject to a complete standardization because all the factors cannot be predicted (patient's age, duration of the diseases et cetera);

9) increased state requirements, especially referred to the subject of their provision (for example, a subject providing medical services must meet qualification requirements, have a license for undertaking medical practice, pass accreditation).

A health protection is such a sphere, where health or life of a person often depends on the time of receiving information. Receiving, processing, and also storage of data in a traditional way are associated with prolonged expectation on information, and engagement of a great number of workers in the process of collection and aggregating of data is often a challenge in case of necessity for using information that is stored. The handwritten form of conducting a medical card and/or medical records has a number of significant defects: lack of structured information, slipshod handwritten records, difficulties in storage of test and medical examinations results, the probability of a loss of medical cards by both a patient and a medical institution ${ }^{2}$. Therefore, the development and the perfection of the technology of electronic information exchange are essential. Special emphasis is placed on the development of methods that allow to collect information in an easy and simple way, and to ensure its storage.

The aim of computerization of medical sphere is to supply citizens with information on their state of health by means of the Internet as well as simplified management, data collection and posting to the insurer, constant monitoring of the patient's health in his location (by tracking the indexes of medical devices introduced to the patient's body). Such teleconsultation can consist in remote control of the vital signals and providing the patient with the corresponding medical treatment without the need for patient's visits to medical institution or his hospitalization.

Computerization of medical service sphere includes: web-sites relating to health, electronic patient databases, system of the electronic procedure reservation, virtual transfer of medical report on the state of patient's health, telemedical services, health portals and other tools based on IT'3.

12 Защита персонифицированной информации в медицинских информационных системах / А. А. Каблуков, Н. А. Иванькова // Запорожский медицинский журнал. -2012. - № 6. C. 91-93. - Режим доступу: http://nbuv.gov.ua/UJRN/Zmzh_2012_6_28

13 Technologie informacyjne w medycynie. Prace Naukowe Universytetu Śląskiegow Katowicachpodredakcją Zygmunta Wróbla. Katowice, 2008. - http://www.sbc.org.pl/ Content/10852/technologie_informacyjne_w_medycynie.pdf 
The main objective of medical information system is the storage, processing and exchange of any medical information concerning the patient (for example, illness, prescribed medications, visits to the doctor et cetera.) that are necessary for accurate diagnosis and /or implementation of other medical measures related to patient's health or life. The offered system provides the use of electronic media capacity (for instance, e-cards, USB flash drives) and allows storing (archiving) all the information by means of the servers located in the most strategic area of the country.

The emergence of electronic medical records resulted in easy use of patient data by doctors, health professionals, nurses, assisting personnel during medical research, as well as providing other services in the field of health protection. Basically, majority of information of health-care assistance, including the patient data is generated not only within doctor and patient relationship, but it emerges from various sources such as practicing nurses, medical institutions, laboratories and other assisting health-care professionals. Due to this capacity electronic data facilitate the control and use of medical data by authorized people.

The success of any type of medical activity largely depends on how well it is provided with the corresponding accumulated and systematized information about patients, their diseases, methods and treatments, and also on how good and skillful a doctor is at using such information in his activity. The computer informative systems give the opportunity to obtain such information very quickly.

Medical information systems (MIS) are used in Europe; they are partially implemented and applied in Russia and other CIS countries. The implementation of MIS into the practice of medical institutions in Ukraine is only a matter of time. The implementation of MIS, centralization and consolidation of medical databases, increased risk of their loss and damage will inevitably lead to the search of the most reliable and secure solutions relating to the protection of personal information that is why comprehensive protection and information security techniques should be provided during the implementation of MIS. This is a massive task because the information integrity is a balance between security and accessibility ${ }^{14}$.

IT systems help medical institutions to reach a new level of efficiency in three key areas: management of their resources and processes; the analysis of current and past activity and decision-making; as well as maintenance

14 Каблуков А. А., Иванькова Н. А. Защита персонифицированной информации в медицинских информационных системах / А. А. Каблуков, Н. А. Иванькова // Запорожский медицинский журнал. -2012. - № 6. - С. 91-93. - Режим доступу: http://nbuv.gov.ua/UJRN/ Zmzh_2012_6_28 
of relationships with patients. Medical informative systems can perform all three functions well or one of them. Similarly, each of the functions can be implemented in a separate software product. It often occurs in many areas, but at present it is more typical of medicine to have a „universal” MIS that performs all three roles.

Each role of MIS has its specified proper name and it often has a kind of a separate subsystem.

Enterprise resource planning or ERP is a system of accounting, control and effective planning of all possible resources: human, time, financial and physical. In MIS it can take the form of different modules: doctor's schedule management, services price list, financial accounting system, warehouse and purchase management module and others.

Business intelligence is responsible for all possible reports with different versions of visualization. Indexes of various fields of hospital activity are inserted into charts and tables that allow the management to be constantly aware of the situation, to see it in real time and analyze trends. It enables a better understanding of own business, a quick respond to changes as well as decision-making based on facts, not just intuition.

Client resource management is for sure the most important component of the MIS. This system provides a great opportunity to work with potential as well as with present clients. It stores all the information about them in electronic records and offers a lot of tools for marketing and improvement of services ${ }^{15}$.

Typical MIS performs the following minimum set of functions: the introduction of documents (paper or electronic); storage of documents; search on issues (both planned and unplanned); editing by operators (nurses); creation of original documents (paper or electronic). It should be taken into account when designing IS that the information needs of managers are different and depend on their hierarchy level, functional responsibilities and types of administrative activity (planning, management control, operational control). Particular importance lies in creation and implementation of the system, its capability of assessing data issued by information system, it allows to recognize and to correct the errors marked by users.

A major technological process in the medical institution is the provision of medical assistance in several stages: diagnostic process, medical process, disease prevention. A data clip is Electronic Health Record (EHR) which contains comprehensive information about the patient's state of health -

15 Лоцман М. Три ролі ІТ в медицині / М. Лоцман // Журнал: 3 турботу про жінку. - № 1 (49) січень-лютий. - 2014. - Режим доступу: http://extempore.info/9-joornal/713-try-roli-it-u-medytsyni.html 
the results of medical examinations, consultations and surveys conducted in different medical institutions. The term Electronic Medical Record (EMR) which is also found in English medical literature is an electronic version of the patient's medical card that is filled out by a specialist, usually a family doctor or a general practitioner, and/or which is available in a local network of a medical institution. In case of applying to the other medical institution a patient receives a printed version of it. EHR is a more complete version of the medical card and provides comprehensive information of the state of the patient's health. The main difference of EHR is that a patient and all people involved in the process of providing medical assistance have an access to available information regardless of medical institution, its location ${ }^{16}$.

A system of electronic medical cards of Poland is an example of an effective implementation of e-health system by which patients are better informed and have an access to the qualitative medical care. It is a depository of computerized information about the health of the subject of the health care system which is securely stored and transmitted and is available to authorized entities. EMC stores digitized information about the state of human health from birth to death. This system is implemented for two main reasons. Firstly, computerization of medical service improves the quality of medical care. Secondly, it helps to optimize and reduce management costs. According to the research the implementation of requirements of the electronic system has reduced the possibility of medical errors by $55 \%$ (e.g. when two medicines that cannot be taken simultaneously were prescribed to the patient).

EMC includes:

- the process of registration of patients and personnel management;

- the delivery of medications, monitoring of the condition of unoccupied beds in a medical institution;

- managerial information;

- hospital administration (accounting, payroll lists);

- patients' management;

- laboratory information systems;

- pharmacy system;

- telemedicine;

- medical institutions communication ${ }^{17}$.

Less attention is paid to the issues related to the information security, but nowadays they are becoming more important.

16 Дячук Д.Д., Зюков О.Л., Гідзинська І.М., Мороз Г.З. Нові можливості збереження та обміну медичною інформацією: електронна історія хвороби, медична картка та персональний портал пацієнта // Український медичний вісник Therapia. 2014. - № 1 (87). С. 52-56.

17 Zenon Wasilewski. Nowoczesne systemy in formatyczne w ochroniezdrowia. - Режим доступу http://it.rsi.org.pl/dane/Nowoczesne_systemy_informatyczne_w_ochronie_zdrowia.pdf 
Information security is a state of protection of information and informative environment against accidental or deliberate, natural or synthetic impacts which may cause unacceptable harm to entities of information relations (including owners and information users). Data protection is a range of measures to ensure information security.

The most common information security model is based on providing three properties of information: confidentiality, integrity and accessibility.

The confidentiality of information means that only a limited number of people provided by the owner can refer to it. If an access to information is received by an unauthorized person, there is a loss of privacy. For some types of information confidentiality is one of the most essential attributes (for example, strategic research data, medical and insurance records, specifications of new products etc.). In certain cases it is important to hold personal information in confidence (for example, medical institutions records about patients' state of health etc.).

The integrity of information is determined by its ability to be stored undistorted. Illegal and unforeseen by the owner changes of information (as a result of an unauthorized person's intentional actions) lead to the loss of integrity. The integrity is especially important for data related to the functioning of critical infrastructure, financial data.

The availability of information is determined by the capability of the system to provide timely unimpeded access to information for entities with relevant authorities. Destruction or blocking of information (as a result of an error or intentional action) leads to loss of accessibility, which is important for functioning information systems focused on customers' service.

In addition to these three properties two more important for information security properties are highlighted: they are authenticity and appeal.

Authenticity is the ability to determine precisely the author of the message. An appeal is an opportunity to prove that the author is exactly that person and no one else.

The most important safety requirements that must be implemented in the systems of electronic circulation of documents are the following:

- authentication and authorization that is verification of the claimed identity and the right to an access;

- integrity (maintaining of data integrity and detection of changes);

- confidentiality (data cannot be divulged to third parties);

- cogency (the verifier may obtain evidence to support the integrity and origin of the data); 
- approval ( receiving, recording, tracking of confirmed consent of a patient to an access to medical data);

- audit (all the actions should be recorded in chronological order);

- version control ( an opportunity to reproduce the state of the MIS at any time in the past).

The problem of information security of health services and the creation of information security system is quite relevant nowadays. It is necessary to understand what threats are possible to face in order to avoid them.

In the opinion of L.O. Larina and T.J. Mazurina the following threats rank as the most important:

- deliberate theft of information within the institution;

- negligence of employees who admitted information leakage;

- hardware and software setbacks;

- malwares;

- external financial fraud;

- hacker attacks;

- natural disasters and hazards.

Nowadays there is almost no purely paper circulation, as computer technologies are used everywhere. Non-cash money, securities, money orders, contracts, customers' data are digitized. Thus, information security threats in the medical field are no longer purely technological but they turned out to be financial, branding, legal and others ${ }^{18}$.

Presently, the entire system of information security management is based on well-known postulate. The customer will not choose a medical service if he doesn't feel confident in saving his money and personal data. Therefore the information security is an integral part of medical services.

All the means of information security can be divided into two groups: internal (prevention of threats coming from internal sources) and external (prevention of threats proceeding from outside). External and internal means of protection are constituent parts of the information security system that functions in a healthcare establishment.

The sources of external threats are as follows: natural systems (astrospace, planetary, physical, chemical, biological); artificial systems (organizational, economic and technical systems, as well as those with mixed nature (for example, biotechnical); abstract systems (symbolic ones (models, algorithms, programs, technological cards et cetera) and descriptive systems (for instance, specifying systems of religious or ethnic character).

18 Ларина О.И., Мазурина Т.Ю. Некоторые аспекты создания информационной безопасности в банке // Деньги и кредит. - 2012. - № 7. С. 61-64. 
Sources of internal threats of the system include subsystems and elements: people, technical devices and systems, technological schemes of data processing, applied in the systems of model data processing, algorithms, programs.

The information security systems that ensure the safety of medical institution include the following means of protection: physical, legal, organizational, software and hardware.

Physical means of protection are based on imposing physical obstacles for an intruder, that prevent him from obtaining information (strict admission system to the area and premises equipped with hardware or storage devices). These measures provide protection only from „external" intruders but do not protect information from those who have the right to enter the premises.

Legislative acts that regulate the rules of using and processing of restricted admission information and that determine criminal liability for violation of these rules are referred to legal means of protection. Standards in the field of information security (international ones, in particular) are of great importance. „The Orange book”, Recommendations of X.800 and "Common Criteria for of IT Security Evaluation" are emphasized among these standards. "The Orange book" is considered to include most basic standard. Major concepts, basic security services are defined in the book and the method of classification of information systems according to security requirements is offered as well.

Organizational one refers to information security by monitoring an access to all system resources (hardware, telecommunication and communication security system, software elements, et cetera). The automated information systems must regulate the workplace policy of users and the staff, the right to an access to information, particular files and databases as well.

The cryptographic information protection devices are the most effective among software and hardware ones, especially in computer networks. When physical protection can be destroyed by remote control, network connections or bribery of the staff, for example, and organizational one does not guarantee safety against attackers' penetration, then the software methods and hardware devices, and primarily cryptographic methods if they meet the requirements are characterized as the methods of the highest „sustainability”19.

The software and hardware protection measures are based on the use of the special hardware and software that make up MIS and serve as protection: encryption, authentification, differentiation of an access to the resources, registration of events, search and virus removal et cetera.

19 Козаченко І.П., Голубєв В.О. Загальні принципи захисту інформації в банківських автоматизованих системах. - Режим доступу: http://bezpeka.com/ 
A special place is occupied by administrative protection measures that is organizational measures which regulate the processes of MIS functioning, personnel's activity as well as user interaction with the system so that to worsen or to prevent from the realization of security threats.

They include:

1. The selection and training of system staff.

2. Security methods and pass control.

3. Registration, storage, usage and destruction of documents and storage devices.

4. Allocation of essential elements of an access (passwords, encryption keys et cetera).

The development of an action plan in the field of information security along with the provision of its implementation (it is necessary to allocate the essential resources and monitor the situation) plays an important role within the administrative protection measures.

The basis of any electronic document management system is the security policy of the organization that is a set of guidelines, rules, procedures and practical security techniques that guide the organization in its activities. The development of security policy includes the determination of the following items:

- what data and how seriously data should be protected;

- who and to what extent is likely to damage the information security of the organization;

- major risks and measures how to reduce them to an acceptable value.

From a practical standpoint the security policy can be roughly divided into three levels: upper, middle and lower.

The upper level includes decisions relating to the organization as a whole (as a rule, they are of a general nature and made by the organization's management). For example, the organization's objectives in the field of information security, action plan in the field of information security (with the appointment of responsible ones for the implementation).

The middle level comprises issues regarding certain aspects of information security but which are important for different systems handled by the organization (for instance, the use of personal laptops at work, the installation of untested software, the use of the Internet et cetera).

The security policy of the lower level concerns specific services and should be the most detailed. The rules of achieving lower level security policy goals often refer to these services at the level of implementation.

Measures of procedure level are certain measures that are performed throughout the life cycle of MIS. They are people oriented (rather than hardware oriented) and are divided into: 
- personnel management;

- physical protection;

- efficiency support;

- respond to the violation of security regime;

- reconstruction planning.

Thus, the organization of MIS includes a wide range of organizational and technical measures that require a lot of resources, but allow to improve significantly the efficiency of providing service in the medical field, especially in terms of time savings, an increase in the efficiency of proving and receiving the necessary information, timeliness of making decisions, including clinical ones.

Currently, there are no electronic document management systems that can provide complete protection. Any system confronts a limited number of well-known threats. The protection devices always fall behind development and thus are vulnerable that is why there is a constant necessity of managing the security system, improving it and teaching staff certain rules of personal data protection.

However, the benefits of implementing systems of electronic circulation of documents are obvious. In addition to traditional advantages of implementation of electronic circulation of documents, such as an improvement of medical care quality, the optimization of patients' expenses and the expenses of health protection institutions, facilitation of an access to medical information, improvement of the efficiency of health-care system, the possibility of receiving complete and reliable information regarding medical services throughout the country, general increase of labour productivity, it is possible to formulate a few more key moments applicable to the field of medical protection:

- a significant reduction in time to make a decision regarding schemes and methods of patients' treatment through a rapid exchange of information among doctors and medical institutions by means of a computer;

- provision of the supervision over all workflow cycle in a medical institution;

- elimination of inconsistencies in the actions of doctors, a per cent reduction in medical errors;

- rationalization of medical staff labour, the reduction of mental and physical exertions.

Nowadays a great majority of medical institutions in Ukraine maintains the medical records only on paper, therefore, a priority measure is the creation of appropriate standards for filling a medical history which will then enable to introduce information to a computer database. A transition 
to active use of modern technology of MIS does not only mean to convert paper documents into electronic ones and then to post them by means of communication channels. This process deals with significant organizational, legal and social changes, and the need to overcome the psychological barrier of health workers' distrust of e-documents.

IT health care system is at the stage of development in many countries throughout the world. Modern trends and goals set by the European Union are aimed at developing European system of electronic medical document circulation according to the EU program „European Health Strategy 2020”. Technological innovations in the healthcare industry provide physicians with new ways of increasing the quality of medical services and improving the state of global healthcare. Patients all over the world continue to benefit from the integration of IT technology into medicine and namely into the areas relating to disease prevention, surgical procedures, a better access to information, and medical telecommunications. 


\section{PIRACY IN THE INTERNET - PROBLEM OF IT SPHERE AND INFORMATION SECURITY}

In the process of development the Internet has transformed from a free network into a commercial one which stipulates the necessity of developing new forms (methods) of control of eligibility of actions of the participants of corresponding relations. The combination of the control of the Internet with the main functions retention and positive moments connected with the nature of this network (free access to information) is necessary. The emergence of the Internet has become the main factor of the transformation of society into informational one in which free access to information, which should be exercised within the law without violation of other persons' rights, is necessary.

The influence of globalization and scientific-technological progress on IT law appearing is manifested in the creation of information space which unites all the countries into one information network the negative impact of which is the spread and speed of persistent violations: commission of acts of piracy; plagiarism in the Internet, independence of borders violations; complexity of control of the intellectual activity results; necessity of an individual approach to piracy and plagiarism control depending on the level of economic development of a country; general world tendencies to increased piracy and plagiarism liability; possibilities of protecting the intellectual property objects regardless of borders; improvement of piracy production quality; creation of new means of objective expression of intellectual property rights objects; opportunities of using the copyright and related rights objects without being bound to a permanent form; technical innovations which make it possible for pirates to bypass the protective measures taken by authors and copyrighters'.

Globalization processes and scientific-technical progress preconditioned not only positive changes in the economy of states. Piracy in the Internet has become one of the violations of law which appeared due to these factors. The contradiction and complexity of the phenomenon raise a lot of issues which need solutions and the introduction of new, more efficient measures in the sphere of protection of author's and related rights.

In the last decades new objects have appeared in intellectual property law, the value and the number of intellectual activity results have increased, authors and copyrighters have got an opportunity to distribute their works

\footnotetext{
Грігор'янц Г. І. Піратство як порушення авторських і суміжних прав в мережі Інтернет: Автореферат дис. на здобуття наук. ступеня канд. юрид. наук: 12.00 .03 / Грігор'янц Галина Ігорівна. - Одеса : Фенікс, 2016. - 23 с
} 
all over the world and receive considerable incomes. Such positive changes led to realizing a real potential of intellectual property in the society. Intellectual property effects economic, political, legislative, social and other relations. The recognition of the value of intellectual property objects also encouraged the processes of development and improvement of statutorylegal regulation of protection of such objects. The growth of law violations in this sphere has become an impact of these processes. Piracy in copyright and related rights has been recognized as one of the most detrimental and wide-spread law violations.

The law on "Copyright and Related Rights" in article 50 defines piracy as publication, reproduction, import into and export from the customs territory of Ukraine, distribution of counterfeit copies of creative products (including software and data bases), audio and video tracks, broadcasting organization programs. In its turn article 1 of the Law states that a counterfeit copy of creative work, audio or video track, is a copy of creative work, audio or video track reproduced, published and distributed with the violation of copyright and (or) related rights including copies of protected in Ukraine pieces of creative work, audio or video tracks which are imported into the customs territory of Ukraine without author's consent or the consent of other subjects of copyright and (or) related rights from countries where these pieces of creative work, audio or video tracks have never been protected or stopped being protected².

As it has been mentioned the arrival of the Internet made it difficult to fight piracy, plagiarism, counterfeiting and other violations of intellectual property rights. The exchange of information has become easier, copyright objects, namely, audio-video, musical and literary works are available in the Internet. To watch a film you need only use the Internet and download it on your computer which makes it possible to save finance and time. However, the eligibility of such actions, financial losses of copyrighters, creators of copyright and related rights objects is disregarded. Due to scientifictechnological progress modern piracy is more far-reaching and infringes on all copyright and related rights objects, created new intellectual property rights objects as well as new means of their objective expression (cassettes, disks etc.) which resulted in appearing of piracy in its modern sense and the distribution, including counterfeit creative products, has become much easier and practically does not require any financial expenses.

Herewith, it is necessary to add that in modern conditions piracy and use of pirated produce by most of citizens is accepted as an ordinary

2 Закон України „Про авторське право і суміжні права” від 23.12.1993 р. // Нормативні акти України: Електронна база даних. - Режим доступу : http://zakon4.rada.gov.ua/laws/ show/3792-12/page2 
phenomenon. Globalization and scientific-technological progress are directly connected with the appearance of new type of piracy which is characterized by a large scope, easiness and speed of conducting pirate actions.

It should be noted that the main efforts of the state are focused on fighting only the piracy effects i.e. restoration of infringed rights, compensation for material and non-material damages, exercising of criminal and administrative sanctions to wrong-doers. In our opinion it is inefficient as it does not allow taking effective measures directed at piracy prevention.

In this connection, first of all, it is necessary to research those social, psychological, economic and other factors which stipulate the fast spread of piracy in the sphere of intellectual property which will make it possible to develop efficient ways of prevention and termination of piracy, protection of copyright and related rights objects.

According to the spheres of influence the main factors of appearing IT piracy can be classified as follows:

1) social-economic: inability of society to adapt quickly to new economic conditions; discrepancy between the needs of an individual person and opportunities of the society and the state; low financial capacity of population; significantly lower prices of unlicensed products or free access to such products; unbalance of prices for legal products and users' financial state; poor financial provision of state employees who are experts in intellectual property which leads to their changing the state companies for private ones;

2) social-psychological: legal nihilism (negligence of legal norms, recognition them as unnecessary); conformism (acceptance of the situation when copyrights are infringed); drawbacks of education, adverse environment (acceptance of piracy as ordinary and even useful phenomenon); social tension in the society; low level of legal culture and legal awareness of the population; extensive advertising of intellectual creativity products, which encourages people's wishes to have them irrespective of their financial state; saving time for searching legal ways of receiving the produce etc.;

3) political and ideological: ideological and political pluralism (for example, acceptance of ideas as to free access to any information in the Internet); poor state policy in the sphere of protection of intellectual property rights; the broadening by the state of the powers of copyrighters along with the restriction of access to intellectual property objects for users with the aim not forbidden by the law etc.;

4) juridical: imperfection of legislation in the sphere of intellectual property rights (insufficient, contradictory and conflicts norms of law); inefficient performance of state authorities in the sphere of security and protection of intellectual property rights etc.; 
5) organizational: lack of proper technical support of security of copyright and related rights objects; complexity of conducting legal expertise connected with violation of rights for copyright objects; complexity of establishing the amount of damage caused by the violation of rights of copyright objects; imperfectness of organizational measures of action against violations in the sphere of intellectual property; insufficient provision of the right for free access to copyright objects with educational and scientific aims etc.

On such background the emergence of new technologies preconditioned the appearance of IT piracy as well. The lack of legislative reinforcement of notions of IT piracy and piracy in the Internet results in discrepancy in the practice of resolution of cases which refer to violation of copyright and related rights in the information space.

Taking into account the mentioned above, depending on the method of distribution of pirated products piracy can be classified into ordinary (traditional) piracy - distribution of pirated products by copying into tangible media and a new type of piracy - piracy in the Internet (kind of IT piracy). Such classification substantiates the necessity of applying new approaches to security of copyright and related rights objects.

IT piracy (as a modern kind of piracy) can be differentiated from ordinary piracy by the following features: distribution, direct connection with the level of scientific-technological progress; independence of borders; high quality of pirated products; support of acts of piracy by the network society; ability to exist without tangible media; complexity of discovery of acts of piracy; difficulty in deletion of pirated content; low price of electronic copies. IT piracy is the most general category which can be defined as the copyright and related rights violation which is carried out with the application of new technical capabilities, characterized by the speed of distribution and high quality of produce, causes damage to the author and (or) copyrighter. Piracy in the Internet network is one of the kinds of such piracy.

Piracy in the Internet network can be defined as violations committed in the digital network which use and spread illegal content with the aim of gaining profit or other benefits which causes damage to the interests of authors and (or) copyrighters at the same time having support from the major part of society who are supporters of free access to information. It is a kind of IT piracy, which is practiced in the sphere of information technologies with the use of innovative technical capabilities, characterised by the speed of distribution and high quality of pirated produce. It is necessary to emphasize its specific feature such as capability to adapt to the conditions of technical, legislative and social development. With the arrival of new devices and media piracy transformed into a technically 
perfect violation, there appeared new methods to override security measures used by authors and copyrighters with the aim of prevention of copyright and related rights violations.

Copyrighters and authors facilitate spreading piracy in the Internet in some way. Inconvenience with payments and complexity of search for licensed content encourages pirates' activity and copyrighters demand to increase responsibility and apply sanctions to as wide circle of persons as possible instead of finding consensus or developing the competition.

The Internet piracy is a specific kind of violations of law, the significant feature of which is the society's attitude to acts which are illegal in nature but for common people they have become an ordinary practice. The Internet is considered by the majority of users as a territory with a free access to information.

Scientific researches suggest an idea of necessity of liability of users of the Internet network for downloading the unlicensed content. It is necessary to agree that violations of law can be justified neither by the fact that we got used to receiving information free, nor that the necessity for information has become the life foundation, nor the pricing policy of copyrighters. However, the introduction of such practice of considerable restrictions and users' liability will not lead to a positive result and only provoke upheaval in the society. In this connection the necessity arises to develop a model of cooperation of copyrighters, users and society in which the interests of all parties will be considered and demands of not only authors but ordinary public will be met. Such cooperation will serve law observance and the formation of negative attitude to acts of piracy.

It is necessary to distinguish specific features of piracy in the Internet which are as follows: perceiving piracy in the Internet by users as a positive and natural phenomenon; absence of borders for acts of piracy; use of innovative technological achievements in conducting such an activity; failure of the state's control of all copyright violations in the Internet; low price of electronic copies.

It is reasonable to differentiate piracy itself and „mild piracy” the essence of which is in copyright violations which cause insignificant material or only intangible damage to author's interests. Herewith, in our opinion, not to provide legal protection of copyright in every case of „mild piracy” would be an unjustified restriction of author's interests. At the same time such protection must be granted along with the consideration of interests of the person who executed the act of piracy as well.

The solution of the conflict of interests which arises in this situation is seen in the establishing additional conditions for assignment of responsibility 
on the person who violated the copyright. It seems reasonable to put a burden of establishing the fact of the act of piracy on the author who claimed the violation of his rights in the case of "mild piracy" and in the case, when insignificant damage or only non-economic damage was established, the responsibility of proving the fact of criminal intent of a wrong-doer. In this way material liability is put on those who purposely violated the copyright and due to this an educational function (not a reparation one) will take a significant part.

Also, concerning the violation of copyright in the Internet network it is possible to distinguish the categories of "piracy" and "quasi-piracy”. The latter resembles piracy by external features but differs in the way that illegal exploitation of copyright and related rights objects is conducted not with the aim of gaining a profit or any other benefit but with the aim of attracting other persons to the results of intellectual and creative activity, their advertising etc. The copyrighter who claimed the violation of his rights as a result of "mild piracy" or "quasi-piracy" should bear the responsibility to prove the fact of criminal intent of the wrong-doer.

The effort to gain a moral benefit which stipulates the distribution of copyright and related rights objects with altruistic motives without gaining a profit with the aim of promoting free access to them is necessary to be distinguished as a feature of "quasi-piracy" as well. ${ }^{3}$

It should be noted that the main attention is concentrated on fighting only the effects of piracy - restoration of violated rights, compensation of material and intangible losses, bringing the wrong-doer up to criminal and (or) administrative responsibility. In our opinion such an approach is extremely inefficient as it does not make it possible to take efficient measures aimed at preventing piracy. Therefore, it is necessary to conduct such state policy that would promote licensed content from an early age, criticize the use of pirated products and explain which particular negative effects the use of such products can lead to.

Information posted in the Internet plays a significant role on the modern level of the development of the society. The restriction of access to information resources is not reasonable as a way to punish users who do not always legally use the posted copyright objects. In our opinion such an approach breaks the main principles of information society and principles of equivalency of punishment to the person's guilt (justice). In order to improve the legislation in effect in the connection with the appearance of the Internet relations it would be reasonable to introduce into the legal environment

3 Грігор'янц Г.І. Піратство як порушення авторських і суміжних прав в мережі Інтернет: Дис. ... канд. юрид. наук: 12.00.03 / Грігор'янц Галина Ігорівна. - Одеса., 2016. - 195 с. 
the categories which are used in the digital network (for example, hoster, content, provider, authorization and others); define the Internet network objects, their rights and duties in terms of legislation. Moreover, it is necessary to develop efficient methods of fighting the Internet crime with the application of modern technological and organizational methods with the regulation of the level and boundaries of state interference into the relations in the Internet.

The list of assignments which should be completed is rather long but the regulation of the mentioned four points will result in the solution to many problems which exist in the sphere of protection of copyright objects in the Internet.

Piracy in the Internet is regarded not only as copyright violation but as a natural phenomenon in the process of development of digital technologies, protest against the restriction of free access to the results of creative activity in the Internet.

In modern society two opposite approaches to piracy in the Internet have been formed. A more widespread one is the approach according to which piracy is considered to be a dangerous, destructive for the society phenomenon which should be fought against. Piracy causes damage to the object's author, country's economy, national culture and society as quality products are not received. According to the other approach piracy is regarded as an inseparable part of modern information society. The main proof-points of supporters of this approach are: 1) society has the right for free access to culture (results of creative work of other people); 2) too high prices for certain pieces of work; 3 ) limitation of some countries to access to creative work (for example, prohibition of some computer games); 4) limited access of citizens to copyright and related rights objects.

First of all, piracy is supported by ordinary people who do not want (cannot) pay money for the content which they can download free from the Internet. However this support is not limited by only such users. It should be admitted that in the sphere of production of copyright and other related rights objects (for example, development of computer games) some authors or copyrighters not only do not criticize acts of piracy but use them as advertising. ${ }^{4}$

One of the main problems, which have arisen for the states in their struggle against piracy, is the support of pirates by the network society. In particular it comes to the creation of political movements aimed at fighting for free exchange of information in the Internet; massive protests in defense

\footnotetext{
4 Грігор'янц Г.І. Піратські партії та їх відношення до піратства в авторському праві / Г.I. Грігор'янц // EVROPSKÝ POLITICKÝ A PRÁVNÍ DISKURZ (Європейський політико-правовий дискурс). - 2015. - № 4. - Том. 2. - С. 153-157.
} 
of sites which were closed because they put unlicensed content, hackers' attacks on sites of state bodies of different countries etc. The statement that all users support free content distribution is inaccurate as a great number of users advocate the interests of copyrighters and authors.

Therefore, not all people consider piracy in copyright and the related rights as only a negative phenomenon and this approach finds more and more supporters, even among authors and copyrighters. The rational kernel in the viewpoint "for piracy" is still and all seen, however it should be specified that it is necessary to fight against this phenomenon but not by the methods of severe forbiddance and great sanctions as such methods will only lead to the consolidation of the society in defense of piracy. Herewith, the protection of copyright and other related rights is necessary and it is not correct and legal to give way to people who stand for free Internet with uncontrolled and free access to its all resources. The example of undue abusive practice of using rights is so called „Declaration of Independence on Cyberspace”. In the modern world the fighting against piracy in the Internet network has become the factor of appearing new rules and order of using the Internet. Two decades ago it was impossible to imagine that technologies would become so widely spread that they would be purposefully used for criminal purposes. Modern development of the right of intellectual property including copyright gives new conditions as to using and acquiring the result of intellectual activity. Information is considered one of the most valuable and important resources which is owned by authors and copyrighters. With the aim of securing the interests of copyrighters free distribution of the results of intellectual property in the Internet is undergoing considerable restrictions. The main problems which arise in the process of securing and protection of copyright and related rights in the Internet are: legislation discrepancy; absence of special norms of regulation of the Internet relations, lack of conformity of the norms with the real situation; low level of legal culture of the citizens, their conviction in the rightfulness of their behavior and fighting for free access to information in the Internet; low level of qualification of government employees and programmers; insufficient financing by the state of measures aimed at fighting piracy; anonymity of the Internet users which makes it difficult or impossible to find lawbreakers and pirates; insufficient level of knowledge of authors and copyrighters in the sphere of copyright; speed of spreading of pirated products in the Internet; difficulty in documenting evidence in the Internet and scarce technological support of people who offset the illegalities.

Elimination of these problems will make it possible to achieve better results in fighting such a complicated and specific phenomenon as piracy in the Internet. 


\section{PLAGIARISM IN THE FRAMEWORK OF INFOSPHERE}

The technogenic civilization of the information society requires a new strategy of interrelation between media, information and the Internet.

The Internet has evolved into a powerful information resource which has its own specific attributes, laws of functioning and development. Despite numerous discussions on the practicability and effectiveness of the legal regulation of relations which take place in the on-line medium, there is a tendency to safeguard certain categories of relations in the field of intellectual property, electronic commerce and IT legislatively.

The relations in the sphere of intellectual activity have experienced a significant impact of the development of information technologies with a digital environment. On the one hand, new technologies develop as a result of the intellectual activity, however on the other hand, the creators and copyright holders face new challenges preventing misuse of intellectual property, as well as protecting the infringed rights.

Legal protection of intellectual property has intensified in consequence of the increase in the number of private websites which are used as data banks'.

In this regard, the balance between new technological capabilities that simplify access to the objects of intellectual property and legal remedies of creators and IPR holders has become of significant importance.

It is worthy of note that existing legislation does not provide a certain list of intellectual property violations on the Internet. However, the development of the Internet has represented new objects of intellectual property along with the new ways of their implementation.

Plagiarism, which has been known through the ages, is one of the most common violations of intellectual property law.

Considering the fact that plagiarism is seen as a violation of intellectual property rights, we should give attention to its legislative definition. The Law of Ukraine "On Copyright and Related Rights" gives the definition of plagiarism, however the explanation of academic plagiarism is foreseen by the Law of Ukraine „On Higher Education”.

Consequently, plagiarism is defined as complete or partial publication of another author's works under the name of a person who is not the author of these works².

\footnotetext{
1 Шишка Р. Б. Атаки на исключительность прав на объекты авторского права / Р. Б. Шишка // Вісник Харківського національного університету ім. В.Н. Каразіна. - 2010. - № 929. - С. 355.

2 Про авторське право і суміжні права: Закон України від 23.12.1993 р. //Відомості Верховної Ради України. - 1994. - №13. - Ст. 64.
} 
V.A. Ermolenko defines plagiarism as complete or partial misappropriation of the authorship that can be expressed only through the actions of the violator indicating the authorship to someone's work or its part. Plagiarism occurs in a case if someone mentions a person who had not been a party to the creation of a piece of work as a co-author or recognizes him or her as a sole author, and/or misappropriates an authorship on a part of a piece of work, created by another co-author, along with an authorship on translation works. Concealment occurs through the alteration of the title of the work as well as the names of the main characters, its plot and ideological conception. Moreover, the application of borrowed imagery is regarded as piracy ${ }^{3}$.

The approaches to the definition of plagiarism are based on such aspects as: misuse of someone's intellectual property; misappropriation of intellectual property; publication of misappropriated works.

Misappropriation of authorship on someone's piece of work is the main attribute of plagiarism that distinguishes it from other intellectual property infringements.

Author's right and moral rights are crucial in the context of intellectual property.

Contemporary Ukrainian juridical doctrine and legislation consider moral rights absolute and inalienable which represent the rights to freedom and integrity ${ }^{4}$.

The right to recognize an individual as a creator (an author, a performer, an inventor, etc.) of the intellectual property right object is embodied in article 423 of the Civil Code of Ukraine ${ }^{5}$. In accordance with the article 14 of the Law of Ukraine "On Copyright and Related Rights", an author may demand recognition of his/her authorship by properly indicating his/her name on a piece of work and its copies and during any public use of the work, if practicable"6.

The right of paternity may be violated as a result of the following actions.

Firstly, in case of misappropriation of authorship, when the name of a person who had not created a piece of work is represented.

3 Єрмоленко В.А. Криміналістична характеристика та класифікація найбільш типових способів вчинення порушень авторського права і суміжних прав / В.А. Єрмоленко // Держава та регіони. - 2011. - №3. - С. 123-129.

4 Кохановська О.В. Поняття та види особистих немайнових прав у цивільному праві України / О.В. Кохановська // Актуальні проблеми цивільного, сімейного та міжнародного приватного права (Матвєєвські цивілістичні читання): матеріал. міжнар. наук. - практич. конф., Київ, 16 вересня 2010 року. - К.: КНТ, 2011. - С. 44-52.

5 Цивільний кодекс України [Електронний ресурс]: - Режим доступу: http://zakon4.rada.gov.ua/laws/show/435- 15/print1400072439709213.

6 Про авторське право і суміжні права: Закон України від 23.12.1993 р. // Відомості Верховної Ради України. - 1994. - №13. - Ст. 64. 
Secondly, the misuse of a piece work or its parts without specifying the author's name, for instance, when an article or a piece of art is posted on the Internet.

Thirdly, the imputation of authorship which is not identified by the scientific doctrine and has no place in the system of intellectual property rights.

The right of paternity may be violated as a result of the following actions.

Firstly, in case of misappropriation of authorship, when the name of a person who had not created a piece of work is represented.

Secondly, the misuse of a piece work or its parts without specifying the author's name, for instance, when an article or a piece of art is posted on the Internet.

Thirdly, imputation of authorship which is not identified by the scientific doctrine and has no place in the system of intellectual property rights.

The nature of the misappropriation of authorship is all about misconducting aimed at making an impression that the intellectual property object (or its essential part) resides to a person who had not taken part in its creation.

The misuse of the author's name lies in the ascription of authorship of a work to a person who is not the author (the so-called „antiplagiarism”). Imputation of authorship occurs either for technical reasons, such as publishing errors for instance, or it may be caused intentionally in order to harm author's honour and dignity, as well as amplify demand for a piece of work by affiliation of a famous author or creator. Ascription of authorship is increasingly being used, especially on the Internet, with the purpose of forming a negative image of a certain person whose authorship is ascribed to. If authorship is attributed to an individual who is not a creator, his moral right-the right to a name which is not an intellectual property right, is infringed. Imputation of authorship and misappropriation of authorship have a common feature: the information is published under the name of person who is not an author of it. At the same time, misappropriation of authorship is undertaken consciously when it comes to plagiarism, whereas the ascription of authorship is committed unintentionally.

In the context of the issues of copyright infringement on the Internet following from plagiarism, it should be remarked that the network serves as the dissemination medium for plagiarism for the reason that many of the works, created as a result of appropriation of authorship, are shared on the internet. This is not just about plagiarism in copyright, though plagiarism is conventionally considered a copyright infringement. However, the misappropriation of intellectual property occurs not only in the area of 
copyright. Copying of design and its basic elements increases in frequency, and industrial plagiarism is mentioned in scientific publications more often. The problem of plagiarism arises in fashion and design industry, mechanical engineering, etc. Misappropriation of industrial design rights takes place when a person, who is not an inventor or originator, represents the industrial property object as his own. As a matter of fact, such actions are regarded as plagiarism. In our view, borrowings within industrial property rights should be divided into two categories: counterfeiting of copyright holder's original products. In this case, offenders create an exact replica of a product using a certain trade mark with the intention to pass of the counterfeit product as genuine. The quality of the counterfeits may differ: some products have apparent signs of falsification and other items are high-quality imitations, which can be distinguished only by an expert; copying of an industrial property, its essential characteristics and representing them as the own product. Such actions are deemed industrial plagiarism.

Secondly, the network may serve as an information resource, which allows to detect plagiarism and prevent the illicit circulation of intellectual property. This issue is particularly relevant within academia. At the present time, academic plagiarism is actively suppressed by: scientists, whose efforts were misused, turning to the editorial boards of journals and publishers to report the facts of plagiarism; higher education institutions which formulate regulations on prevention of plagiarism and implement special programmes to detect plagiarism in scholarly papers; ordinary citizens who reveal the facts of plagiarism and report these facts by posting the relevant information mainly on the Internet.

Moreover, there are special open access programmes on the internet which allow to detect plagiarism in scientific papers. Computer programs have advantages and disadvantages: the difficulty may be that the programme detects all matches, however not all of them are plagiarism. Therefore, all plagiarized texts must be highlighted. These programmes, however, detect and report the cases of illicit borrowing and authorship misappropriation.

Full versions of scientific articles and dissertations which are posted on the official websites of academic journals and libraries not only allow to leverage scientific achievements when writing research papers, but also reveal cases of misuse of any material.

Thirdly, intellectual property is created in order to ensure the functioning of the Internet. Intellectual property becomes a subject of infringement and misappropriation of authorship.

Plagiarism of web page content is an extensive violation of intellectual property rights. 
From a legal point of view, websites have certain elements which are safeguarded, however their legal regulation and protection may differ. First of all, attention should be given to a program that provides core functions of the site. As a framework of a website includes its design, fonts, data placement layout, textual and graphical information, audio-video data, a website should be regarded as a database. In addition, websites can host different intellectual property which is protected by the rule of applicable legislation. Consequently, a website or its elements are the subjects of intellectual property. Scholars offer to protect certain elements of the web page as different kinds of intellectual property, for instance: the executive program and original selection of material should be protected as copyright, however its design and page layout should be protected as an industrial design.

Plagiarism of the site content is the misuse of the texts, photos and videos published without the consent of an author, right holder and an active reference to the source, which should be placed on each page.

A plagiarist misappropriates intellectual property and its elements, for that reason the determination of protectability of borrowed elements is of significant importance in the context of plagiarism.

In accordance with the article 9 of the Law of Ukraine „On Copyright and Related Rights", the part of a work that can be used independently, including the original title of a work, shall be considered a work and shall be protected. The conditions for legal safeguard of the part of a work are based on the following provisions of the Law: creative nature and objective expression (as the principal provisions of protectabibility of a piece of work); feasibility of independent using; originality of the title.

When it comes to the assessment of a part of work which may have been plagiarized, following aspects should be considered.

Firstly, it should be determined whether a piece of work belongs to the category of intellectual property which is not a subject to legal protection or not.

Secondly, if the disputable fragment is included in the list of protectable objects, then it is determined whether the part of work meets the criteria of protection prescribed by the Law. It is necessary to apply two criteria in the course of detection of plagiarism: volume of the work and essential content of the borrowed fragment. These two criteria should be accounted simultaneously, in view of the fact that each object of copyright has its peculiarities, structure and content.

Any verbatim reproduction of someone's text with more than 15 words or 100 characters, which is represented improperly (when an author is 
not contributed) without an active hyperlink, is regarded as plagiarism of web content. Additionally, playback of any video which is longer than 15 seconds (when an author is not contributed) is regarded as plagiarism of web content. Minor site content plagiarism is called paraphrase (in Greek-Paraphrasis). That is rewording of someone's text through the substitution of words and phrases without altering the semantic content of the borrowed text? ${ }^{7}$.

Such on-line services as copyscape.com and antiplagiat.ru provide free check and detection for unique content. ${ }^{8}$

Misappropriation of promotional materials on the Internet is distributing rapidly.

It should be noted that advertising as intellectual property may consist of different results of creative activity. Typically, advertising is a combination of different objects of copyright such as music, art and literature. In addition, the brand identity is an essential part of advertising which is protected as intellectual property.

Advertising as a complex product is a combination of heterogeneous results of creative and intellectual activity (music, songs, poems; objects of related rights; objects of industrial property-trademarks, geographical indications) which are interrelated and constitute an integrated object of the intellectual property.

The restriction on misappropriation of promotional materials is provided by several statutes. Consequently, in accordance with article 8 of the Law of Ukraine „On Advertising”, it is prohibited to imitate or copy the texts, images, music or sound effects used in advertising of other goods unless otherwise is provided for by laws of Ukraine in the field of intellectual property.

Specialists, rights holders and users may find a lot of information on identical advertising. However, the problem of plagiarism in advertising is frequently mentioned. In this regard, the question arises: whether the action of borrowing of promotional materials may be qualified as plagiarism?

Actually, remarkable ideas and concepts of advertising may bring profit. In most cases, any advertising campaign requires an advance approval of promotional material. As a result, the risk of unfair acts occurs on the part of an advertising customer. If the customer is aware of materials, then he or she may repudiate the advertising contract and apply the promotional materials in one's own use without any permission.

\footnotetext{
7 Ответственность за плагиат контента сайта /сайт Веб-студии „Антула”. - [Электронный ресурс]: - Режим доступа: http://www.antula.ru/patent- 2.htm.

8 Щукин П. Обзор сервисов для проверки контента на уникальность (плагиат) [Электронный ресурс]: - Режим доступа: http://mexboy.su/?p=43.
} 
Therefore, it is necessary to specify that any concepts, ideas, and materials that may be known to the customer, are a trade secret and belong to the advertiser. This provision ensures the rights and interests of advertisers when concluding a contract.

The advertising plagiarism and sabotage are considered in the context of Internet plagiarism. Advertising plagiarism is intended to attract customers or visitors through the misuse of headings or keywords, as well as popular names or titles that have nothing in common with the plagiarist's website. Sabotage is a kind of deliberate plagiarism as well. It pursues the same purpose as advertising plagiarism, however, it includes headings, keywords and names of those sites which are antipodes of the site and, therefore, are able to show well-known people or popular websites in a bad light. Some plagiarists use special techniques allowing not to leave the website. Moreover, that can make harm to a computer ${ }^{9}$.

As it happens, that use of well-known names may not always be regarded as plagiarism. If any advertisement, which is aimed to attract consumer's attention, cites the names of famous people without their permission, this case should be regarded as a violation of moral right - the right to the name which is not associated with intellectual property. However, any misuse of the advertising fragment, which includes the name or image of a famous person, may be considered plagiarized advertising.

As a result, misappropriation of advertising material has the following signs of plagiarism: use of promotional material without permission of the copyright owner; use of promotional materials on behalf of the person to whom the copyright belongs to. The issue of violation of moral rights, when promotional materials are copied improperly, is becoming more challenging. Therefore, any misuse of promotional material may primarily harm the advertising customer.

From this perspective, the matter of protection of both advertising customer's and author's interests arises. Misappropriation of promotional materials cannot be regarded as plagiarism along the lines of the definition, represented by legislation, as the author of advertising is not indicated. Advertisement is released on behalf of the customer, but not the author. However, any misuse of advertising materials is essentially plagiarism.

Replication and rewriting are new forms of misuse of the results of creative activity which may conceal the fact of borrowing the information materials.

9 Поис А. Особое мнение. Нестандартная точка зрения. Ответы на вопросы: Сборник статей [Электронный ресурс]: /А. Поис //2005-2008. - С. 4. - Режим доступа: www.pois.ru/ vo/osm.doc 
Rewriting and replication are administered by the internet media. These methods of borrowing allow saving money and time.

Replication is regarded as a kind of plagiarism in the internet media. According to the Wikipedia, replication (in other words, copying) involves sharing information so as to ensure consistency between the redundant resources. However, sometimes replication may lead to the distribution of mistakes, which had been made for certain reasons. That gives rise to misleading information ${ }^{10}$.

Rewriting is the other way to use the information on the Internet that involves informational and meaningful paraphrasing of someone's materials. Actually, rewriting is plagiarism, as misappropriation takes places, though it is inconspicious.

Despite the fact that rewriting may not be recognized as fair use of information materials, it is not provided as a violation of intellectual property. Moreover, it is very difficult to establish a fact of rephrasing, especially when it comes to current events and well-known facts that may be acquired from open sources of information and news. To the date, rewriting is a kind of „professional” activity. Many websites offer professional rewriting services.

There are two basic types of rewriting: plain and complex.

In the first case, the words from authentic text are substituted with their synonyms. Synonimyzer is a special software which is used for rewriting. This program hastens the creation of promotional materials. Search engines regard these texts as unique, however the original text may be still recognized and a reader may notice that if he had already read it somewhere else.

Complex rewriting in its turn, which is provided for serious sites or publications, is in the mould of copywriting. However, the principle of copywriting and rewriting is the same - rewriter does not alter the meaning of the text ${ }^{11}$.

In conclusion, the development of technologies and Internet has resulted in new challenges and opportunities for intellectual property. The new methods of misuse and misappropriation of intellectual property necessitate the identification of new approaches to the legal regulation of relations in this area.

10 Панасенко А.Р. Явище плагіату в українській інтернет-журналістиці // International Scientific and Practical Conference „WORLD SCIENCE” № 4(4), Vol.4, December 2015.

11 Давиденко O.A. Рерайтинг интернет-текста: прийомы T принципы URL: http://naub.oa.edu.ua/2012/rerajtynh-internet-tekstu-pryjomy-ta-pryntsypy/ 


\section{LEGAL LIABILITY FOR INTERNET COPYRIGHT INFRINGEMENT}

One of the effects of the modern world of globalization and informatization, the rapid development of information and communication technologies, including the Internet has resulted in its regulation as a necessary condition for the development of every democratic legal state.

Intellectual property protection is essential guarantees provided by ch. 1, Art. 41, ch. 1.2 Art. 54 of the Constitution of Ukraine. It's very important to ensure their implementation through the adoption of new regulations and bringing changes to existing ones in terms of regulating the relations concerning copyright on the Internet.

To ensure effective protection of copyright when using the corresponding objects in the network there should be required the opportunities of prosecution of various subject categories who are responsible for the creation of conditions for fair use of copyrighted works.

Considering these issues, we note that a complex legal act regulating relations concerning Internet copyright does not exist. However, according to Art. 1 of the Law of Ukraine "On Copyright and Related Rights" and explanations provided in the Resolution of the Plenum of the Supreme Commercial Court of Ukraine "On Certain Issues of Disputes Related to the Protection of Intellectual Property", placing the pieces of works on the internet accessible for public use is their reproduction. If in connection with the deployment the property rights of copyright holders are violated by Art. 15 of the Act it gives rise to legal protection of the copyright.

Paragraph 3 of the above said Regulation states that the responsibility for violation of intellectual property rights in the form of damages caused to the subject of the law can only occur at simultaneous presence of the following conditions: 1) the fact of the wrongful conduct of the defendant (including nonconformity of the copyright conditions, licensing agreements, the use of intellectual property without authorization holder); 2) damage to an intellectual property rights holder; 3) a causal link between the unlawful behavior of individuals and prescribed damage; the fault of the person who caused the damage.

Analyzing the above sources and works of scientists we can conclude that the legal responsibility for copyright and related rights can be understood as statutory kind and extent of forced deprivation of any personal, organizational and property nature benefits for an offense in the field of copyright and related rights. The qualifying features of the legal liability for 
copyright infringement on the Internet are as follows: 1) the place of this type of crime is a global network - the Internet; 2) subjects of copyright offenses in the global network are always the persons who are its users.

According to Art. 432 of CC of Ukraine everyone has the right to go to court to protect their intellectual property in accordance with Art. 16 of the Code.

According to the requirements of Art. 52 of the Law of Ukraine "On Copyright and Related Rights" the court may decide on: a) compensation for moral (non-property) damage caused by infringement of copyright and (or) related rights with the defining of compensation; b) damages for infringement of copyright and (or) related rights; c) recover from the infringer of copyright and (or) related rights of income derived from the violation; d) payment of compensation determined by the court ranging from 10 to 50,000 minimum wages instead of compensation or recovery of income; e) the ban for the publication of works, their performances or productions, issue of phonograms copies, their notification, termination of their distribution, withdrawal (confiscation) of counterfeit copies of works, phonograms or broadcast programs, equipment and materials for the production and reproduction, publication in the press of information about the violations etc. if in course of the trial it is proved to be a violation of copyright and (or) related rights or the existence of actions that threaten the violation of these rights; e) require from persons who violate the copyright and (or) related rights of the plaintiff information regarding the third parties involved in the production and distribution of counterfeit copies of works and objects of related rights, circumvention of technical means and channels of distribution.

In determining the amount of damages to be recovered to the person whose rights have been violated as well as for non-pecuniary (nonproprietary) damages the court must proceed from the nature of violations, property and moral damage caused by the person holding the copyright and (or) related rights as well as the possible income that the person could get. In the amount of damage caused to a person whose rights are violated the costs and expenses incurred by that person as well as the costs associated with the payment of a lawyer may additionally be included.

If the subject whose rights have been violated did not submit reasoned losses or profits in $90 \%$ of cases for compensation the court appoints the compensation of 10 minimum wages i.e. minimum amount regardless of the number of offense objects.

To be of great scientific interest is such kind of legal protection of copyright on the web as a claim for compensation as referred to in paragraph 
9 of Part 2 of Art. 16 of the Civil Code of Ukraine. In the case of an authorized person's claim for compensation the court may decide to pay compensation in the amount of 10 to 50,000 minimum wages instead of compensation or income collection. As follows from the content of the rule and confirmed by judicial practice in dealing with such cases compensation is payable in case of the proof of violation of property rights of the subject of copyright rather than the size of the losses?.

The institute for copyright compensation infringement is relatively new in the civil science. But despite its novelty this method of copyright protection has gained quite considerable popularity because the plaintiff is not required to justify either availability of any damages or compensation claimed as it is within the jurisdiction of the court ${ }^{2}$.

The recovery of compensation for copyright infringement seems to be the measure of civil liability (similar to a penalty considered as a means of ensuring commitment and penalty as a degree of responsibility) ${ }^{3}$.

The institute for copyright compensation infringement is borrowed from the Anglo-American legal system where it is known as statutory damages. In particular the US statutory penalty of loss is one of judicial civil legal ways of copyright protection provided by $\S 504$ (c) of the Copyright Act of the USA 19. 10. 1976 ${ }^{4}$. However, the Supreme Court denying Germany under reservation of public order in recognition of the decision of the American court concerning the recovery of punitive damages stated that the German private law provides reparation as a legal consequence of illegal actions rather than enriching of the victim. EU Directive number 2004/48/EC provides for financial compensation if the violation of intellectual property has been committed without fault. If there is a fault of the offender, he must compensate the damage 5 .

Moreover, despite the position of the European Court of Human Rights the case for compensation for copyright infringement should be regarded as criminal in compliance with all the rules of criminal procedure justice (presumption of innocence, interpreting of all doubts in favor of the accused

1 Філик Н.В., Троцюк Н.В. Специфіка судового захисту авторських прав на об'єкти розміщені в мережі Інтернет: порівняльно-правовий аналіз // Науково-практичний журнал „Судова апеляція". - 2012. - № 2(27). - С. 47-54.

2 Кохановська О.В. Правове регулювання у сфері інформаційних відносин. - К. Національна академія внутрішніх справ України, 2001. - 212 с.

3 Гонгало Б.М. Обеспечение исполнения обязательств. - М. : Спарк, 1999. - 152 с.

4 Мирзоян С. Гражданско-правовые способы защиты авторских прав: законодательство, доктрина и судебная практика // Авторское право и смежные права. - 2003. - № 7. - С. 42-67.

5 Фелицына С. Б., Антипина И. Г. Директива Европейского Союза о защите прав / Подобщей ред. С.Б. Фелицына // Изобретательство. - 1994. - № 13. - С. 10, 64. 
etc.). The failure to comply with these rules may become the grounds for challenging the relevant decision of the European Court of Human Rights for breach of the European Declaration of Human Rights ${ }^{6}$. Article 67 of the Law of the Republic of Lithuania „On Copyright and Related Rights” includes the right of copyright holders to demand reparation instead of compensation the amount of which is calculated from the price of the legitimate sale of the works or objects of related rights with an increase by 200 percent, in case of the intention of the offender up to 300 percent $^{7}$. The actual implementation of copyright protection in the global network seems problematic due to the international nature of the offenses. Thus, according to P.A. Kalenychenko neither the Law of Ukraine „On International Private Law” nor other regulations concerning this issue do not give a clear answer to the question of the possibility of considering disputes in the Ukrainian courts in terms of protecting the rights of Ukrainian copyright holders or related rights violated as a result of the unlawful posting on the Internet the works or objects of related rights of foreign citizens or legal persons. The author notes that "the possibility of further consideration of these cases is questionable seeing that the procedural rules require the proof of the defendant notification on the opening of proceedings, the time and place of hearings etc. and to submit such evidence in practice does not always seem possible as the court requires clear evidence of the location of the defendant, his registration in the commercial register etc." 8 .

The confirmation of a copyright violation due to the requirements of Art. 33 of the Civil Code of Ukraine the parties are obliged to provide evidence to the court. The plaintiff must prove the copyright belongs to him and the usage of these rights data by the defendant thus in case of claiming for the reimbursement of damage - the damage and the causal link between the damage and the actions of the defendant. The defendant must prove compliance with the requirements of the Civil Code and the Law of Ukraine „On Copyright and Related Rights” by using its work and to refute the presumed perpetrator of harm according to the civil law (art. 614, 1166 of CC of Ukraine).

In accordance with the provisions of Resolution of the Plenum of the Supreme Commercial Court of Ukraine „On Certain Issues of Disputes Related to the Protection of Intellectual Property Rights" in this category of

6 Староженецкий В.О. О природе компенсаций за нарушение исключительных прав // Авторское право и смежные права. - 2003. - № 8. - С. 21-33.

7 Підопригора О.А., Святоцький О.Д., Мельник О.М. та ін. Право інтелектуальної власності: Підручник для студентів вищих навч. Закладів. - К. : Ін Юре, 2002. - 624 С.

8 Калениченко П.А. Проблеми охорони авторського і суміжних прав в мережі Інтернет // Часопис Київського університету права. - 2009. - № 2. - С. 192-199. 
cases the data regarding the web site owner can be obtained in accordance with paragraph 4. 65, p. 38 Ukraine CPC from the administrator of the registration system of domain names and addresses of Ukrainian segment of the network. Web pages are electronic documents ${ }^{9}$ that cannot be delivered to the court but on the basis of Art. 32, Part 1 of Art. of 36 of CPC of Ukraine may conduct the review and investigation of the evidence in their location with fixing appropriate proceedings in the minutes which must meet the requirements of Art. 811 of CPC of Ukraine. Besides the current legislation provides for the use of video, audio recording process research by any interested party of the site regarding which there is evidence of its use in violation of copyright. The written evidence may also be the notes received from network providers and search services. Web pages printouts themselves cannot serve as evidence in the case. But if documents issued or certified be the agency or authorized person within its jurisdiction in the prescribed form and stitched with the official seal in one of the countries of the Commonwealth of Independent States, according to Art. 6 of the agreement procedure for resolving disputes related to economic activity from 20.03.1992 they are on the territory of Ukraine of probative value ${ }^{10}$.

Domestic legislation provides for the appointment of judicial examination according to the requirements of the Plenum of the Supreme Economic Court of Ukraine of 23.03.2012 Number 4 „On Certain Issues of a Judicial Expertise” and „On Certain Issues of Appointment of Judicial Examination in Cases of Disputes Related to Protection Intellectual Property Rights" from 23.03.2012 № 5 .

The issues regarding definition of the entity responsible for counterfeiting in the global network attract certain attention. The defendants in this category of cases can be both physical and legal persons. Persons who have committed acts that violate copyrights are recognized as copyright infringers.

Quite controversial is the question of liability of ISPs. According to p. 4. Art. 40 of the Law of Ukraine „On Telecommunications" telecommunication operators and service providers are not responsible for the content of information transmitted via their networks ${ }^{11}$. In accordance with the

9 Про електронні документи та електронний документообіг: закон України від 22.5.2003 № 851-IV // Відомості Верховної Ради України -2003. - № 36. - Ст. 275.

10 Про деякі питання практики вирішення спорів, пов'язаних із захистом прав інтелектуальної власності : постанова Пленуму Вищого Господарського Суду України. - Режим доступу: http://zakon2.rada.gov.ua/laws/show/v0012600-12.

11 Про телекомунікації : Закон України від 18.11.2003 № 1280-IV// Відомості Верховної Ради України. - 2004. - N 12. - Ст. 155. 
decree of the Cabinet of Ministers of Ukraine "On Approval of Rules of Telecommunication Services Provision and Receipt" ${ }^{12}$ an operator or a provider is not responsible for the content of information transmitted (delivered) by the consumer.

Deserves support a position concerning the Internet counterfeiting according to which in many cases the court can draw a host, a provider, an operator of Internet resources as a third party to establish the facts of the case $^{13}$.

Since the legislation of Ukraine exempts providers from liability for the content of the information used in communication systems of their clients, regulation of relations provider-client and provider-holder is mainly on contractual and pretentious level ${ }^{14}$.

Noting the important role of civil responsibility in the protection of authors' rights on the Internet at the same time it should be noted that in Ukraine the role of administrative responsibility as a hard way to combat infringements of intellectual property rights has significantly increased. However, the problem of administrative responsibility for infringement of copyrighted works as part of intellectual property rights which in today's environment requires special analysis still needs to be explored.

The literature rightly states that the imposition of administrative penalties occupies a special place in coercive measures. The peculiarity of administrative penalties is that they have a pronounced "sanction character" and that are different from other types of coercive measures ${ }^{15}$.

Administrative responsibility for violation of rights to object of intellectual property rights inherent in a number of specific features that allow you to separate it from other types of liability. They are connected with the basis of its origin, the nature of activities of its influence and the application procedure.

The main reason for the existence of an independent administrative liability for copyright infringement is a public danger especially in terms of Internet offenses. It is encroachment on the established order of property

12 Про затвердження Правил надання та отримання телекомунікаційних послуг: постанова Кабінету Міністрів України від 11.04.2012 № 295. - Режим доступу: http://zakon0.rada.gov.ua/laws/show/295-2012-\%D0\%BF.

13 Філик Н.В., Троцюк Н.В. Специфіка судового захисту авторських прав на об'єкти розміщені в мережі Інтернет: порівняльно-правовий аналіз // Науково-практичний журнал „Судова апеляція". - 2012. - № 2 (27). - С. 47-54.

14 Рекомендації для Інтернет-провайдерів, контент-провайдерів та користувачів файлообмінних мереж та інших веб-сервісів щодо правомірного використання об'єктів авторського права і суміжних прав у мережі Інтернет / Рекомендації державної служби інтелектуальної власності України. - Режим доступу: http://sips.gov.ua/ua/ip.html.

15 Матіос А.В. Адміністративна відповідальність посадових осіб : навчал. посібн. - К. : Знання, 2007. - 223 С. 
rights use and the availability of objective necessity of a special allocation of administrative and legal protection of these relations ${ }^{16}$.

Based on the characteristics of copyright infringement on the Internet it can be concluded that the administrative responsibility is the existence of special legal norms enshrined in law and decisions authorized by the authorities to bring the perpetrator to administrative liability for copyright infringement on the Internet.

The legislation of Ukraine like many other countries establishes administrative responsibility for violation of copyright and related rights. Administrative measures to combat offenses in this area are effective means of influence on offenders. Advantages of some administrative sanctions lie in the simplicity and speed of their implementations.

The main act regulating administrative responsibility for copyright is the Code of Ukraine on Administrative Offenses (CUAO) ${ }^{17}$.

Thus, illegal use of intellectual property (literary or artistic works, their performance, phonogram, broadcasting organization's transmission, computer programs, databases and scientific discovery, invention, utility model, industrial design, trademark, topographies of integrated circuits, innovations, plant varieties etc.) assigning of authorship on such objects or another intentional infringement of intellectual property rights object is protected by law thus entails a fine ranging from ten to two hundred of the income tax exemption with seizure of illegally manufactured products and equipment and materials for their production (Art. 512 CUAO).

However, some authors believe that the rate of this article is not sufficient to establish full administrative responsibility for violation of intellectual property rights including copyrights. For example, according H.V.Korchevnoho p. $51^{2} \mathrm{CUAO}$ cannot be applied to violations of the moral rights of the author which leads to the need for a separate article responsibility for violation of moral rights of the authors ${ }^{18}$. According to Art. 52 of the Law of Ukraine „On Copyright and Related Rights" the court may impose on the infringer of copyright or related rights a penalty of $10 \%$ of the amount awarded by the court in favor of the plaintiff. The withdrawn amount of the fine passes in the prescribed manner to the State Budget of Ukraine. Above said authorization which has

16 Гладун 3.С. Адміністративне право України : навчал. посібн. - Тернопіль : Юридична література, 2004. - С. 53.

17 Кодекс України про адміністративні правопорушення : Закон України від07.12.1984 № 8073-Х // Відомості Верховної Ради Української РСР. - 1984. - додаток до № 51. - СТ. 1122.

18 Корчевный Г.В. Административная ответственность за нарушение авторских и смежных прав : дисс. ... канд. юрид. наук : 12.00.07. - Одесса, 2002. - С. 230. 
administrative and legal nature is an additional means of punitive effect on offenders whose actions violate the property interests of copyright holders. Courts do not use it alone but only together with damages in one of the forms permitted by law and it depends on the size of the sums awarded to the claimant ${ }^{19}$.

The code of Ukraine on Administrative Offenses contains a number of articles dealing with issues of administrative responsibility for violation

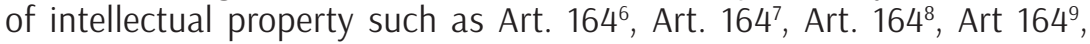
Art. $164^{13}$. However each of these items in the disposition comprises provisions for the presence or absence of a state certificate for distribution and demonstration movies. The Cabinet of Ministers of Ukraine "On Approval of the State Certificate for Distribution and Demonstration of Films" from 17.08.1998 the right to distribute the film and the right of the film screening applies only to cinema theatre law, public commercial video and television rights.

Thus, we can conclude that the application of the provisions of Articles century. $164^{6}$, Art. $164^{7}$, Art. $164^{8}$, Art. $164^{9}$, Art. $164^{13}$ of the Code of Administrative Procedure of Ukraine to copyright infringement on the Internet is impossible.

According to the Single State Register there is a small amount of court decisions in administrative proceedings concerning the copyright on the web ${ }^{20}$. However, the analysis of judicial practice in cases of administrative violations of intellectual property suggests that judges do not always correctly set the object of illegal encroachment in the cases under Art. 51- 2 CAO of Ukraine thus taking judicial decisions and assigning confiscation of items that are not manufactured illegally and do not belong to the equipment and materials used in the illicit manufacture of products. As evidence of this we'd like to give an example. Kyiv district court of Kharkiv by the order dated 26.05.2003 drew to administrative responsibility for offenses whose crime under Art. 51-2 CAO Ukraine with the imposition of penalties in the form of a fine of ten non-taxable minimum incomes of citizens and the state confiscation of the system unit on a processor AMD ATLON HDD at total cost of 3 thousand UAH. Analyzing the materials of the case there has been found out that citizen $S$. was fined for using two computer software system unit „Windows XP" which documents of acquisition and its registration number were

19 Дроб'язко В.С. Адміністративна та кримінальна відповідальність в Україні за контрафакцію і піратство у сфері авторського права й суміжних прав // Теорія і практика інтелектуальної власності. - 2013. - № 3. - С. 48.

20 Єдиний державний реєстр судових рішень. - Режим доступу: www.reyestr.court.gov.ua. 
missing. Having qualified correctly the offender's action in accordance with the Art. 51-2 CAO the court incorrectly applied the confiscation of the above equipment as the object of intellectual property rights of company "Microsoft” is only the computer program "Windows XP" which is copyrighted but not the device to which it is set ${ }^{21}$.

The above seems to be indicating that the specific violations of copyright on the web necessitates the improvement of the position of the legislator on this issue. The best solution to this problem would be the unification of the rules of the Code of Ukraine on Administrative Offenses and other regulations on liability for copyright Internet infringement.

In addition to civil and administrative liability for copyright Internet infringement should be criminal responsibility.

TRIPS Agreement requires from States belonging to the WTO the provision of criminal penalties for copyright infringement (Art. 61) in their national laws ${ }^{22}$. The duty to provide responsibility for the illegal manufacture and sale of objects of copyright or related rights also relies on the Parties to the Convention „On Protection of Producers of Phonograms Against Unauthorized Duplication of their Phonograms” from 29.10.1971 (Art. 2) and Berne Convention „On Protection of Literary and Artistic Works" from 09.09.1886 (Art. 16).

According to Art. 176 of the Criminal Code of Ukraine of 05.04.2001 (Hereinafter - the Criminal Code of Ukraine) the criminally offensive are deliberate illegal reproduction, distribution of copyrighted works if it caused damage in significant, large or extremely large scale ${ }^{23}$. The crime provides for the punishment in the form of fines, corrective labor or imprisonment with confiscation and destruction of all copies of works, material media with computer software, databases.

In Part 1 of Art. 176 Criminal Code of Ukraine stipulates four forms of commission of the offense: 1) illegal reproduction of works of science, literature and art, computer programs, databases, performances, phonograms and broadcasts; 2) illegal distribution of works of science, literature and art, computer programs, databases, performances, phonograms and broadcasts; 3) illegal copying and distribution of performances, phonograms and broadcasts on audio and video cassettes, floppy disks and other storage media; 4) other willful infringement of copyright and related rights.

21 Колесніков М.А. Узагальнення застосування судами законодавства у справах про адміністративні правопорушення у сфері інтелектуальної власності. - Режим доступу: http://www.justinian.com.ua/article.php?id=3249.

22 Implicationsofthe TRIPS AgreementonTreatiesadministeredby WIPO. - Reprint. ed. Geneva: WIPO publ., 2011. - 83 p.

23 Кримінальний кодекс України : Закон України від 05.04.2001 № 2341-ІІІ // Відомості Верховної Ради України. - 2001. - N 25-26. - Ст. 131. 
Sanctions for seen by the Art. 176 of the Criminal Code of Ukraine provide for alternative penalties (fines, correctional work, arrest, restraint, imprisonment) which is the general trend of the Criminal Code of Ukraine. This article also contains a note that material damage will be considered on a significant scale if its size twenty or more times exceeds the nontaxable minimum of citizens' incomes, on a large scale if its amount equals or exceeds income tax exemption and inflicted on an extremely large scale if its size a thousand and more times exceeds the untaxed minimum incomes.

Scientists emphasize that a significant reason which leads to inefficient use of above said rules is insufficient scientific study of the mechanism of criminal law protection of copyright and related rights. Thus, according to M.I. Korzhanskoho infringement of copyright and related rights are committed only intentionally, any error in the use of copyright and (or) related rights does not form a crime. S.O. Dovgiy believes that the subjective side „of copyright and related rights" is characterized by the intent. This means that the offender is aware of the danger of his actions (or inaction), provides its socially dangerous consequences and wishes or knowingly allows their occurrence ${ }^{24}$.

The commission of actions out of negligence referred to in Art. 176 CC of Ukraine does not constitute a crime and does not entail criminal liability. It should be noted that in the law enforcement practice there are certain difficulties due to the fact that the disposition of Part 1 of Art. 176 of the CC of Ukraine criminalized violation of copyright and related rights is recognized only intentional violation of these rights. Some scientists expressed proposal concerning the feasibility for exclusion from the disposition of Part 1 of Art. 176 of the Criminal Code of Ukraine of the word „intentional" and criminalize both intentional and inadvertent breach of copyright and related rights ${ }^{25}$. It's very difficult to agree with these proposals. Since criminal liability is the most severe type of legal responsibility it is advisable to use other types of liability (civil, administrative).

According to M. Melnikov lawmakers should increase the level of penalties for criminal offenses in this area taking into account the level of danger to society ${ }^{26}$.

An interesting idea of $A$. Stephan regarding the fact that although criminal liability for copyright infringement occurs only in case of a violation

24 Коваль А.М. Історико-правові аспекти кримінальної відповідальності за порушення авторського права в Україні // Адвокат. - № 2. - 2005. - С. 12.

25 Коваль А. Порушення авторського права і суміжних прав: кримінально-правові проблеми, які потребують свого вирішення // Юридична газета. - 2005. - № 15. - С. 6.

26 Мельников М. Піратство як злочин у галузі авторського права і суміжних прав: погляд на проблему // Право України. - 2003. - № 4. - С. 72-75. 
of property rights, however the norm of Art. 176 of the Criminal Code of Ukraine is in section $\mathrm{V}$ - Offenses against electoral, labor and other personal rights and freedoms ${ }^{27}$. The author supports the position that the object of the crime in question is the exclusive property rights of authors, performers, producers of phonograms and videograms, broadcasting organizations since the responsibility occurs for illegal set of actions due to the exclusive right to authorize or prohibit such use. Offers concerning dissemination of criminal protection for the moral rights of intellectual property ${ }^{28}$, in our opinion, is not quite correct, because part 1 of the art. 11 of the Criminal Code of Ukraine recognizes a crime as an act which is characterized by a high degree of public danger and the violation of the moral rights of the author are not always likewise. An important argument against the position of A. Nersesian is that the main reason for criminalization of copyright infringement problem is substantial damage to property interests of copyright.

The researchers have also no consensus as to what can be considered a generic object of this category of crime. Some believe that is the target of copyright and related rights ${ }^{29}$. Others recognize social relations as the generic object crimes in the area of copyright and related rights protected by the criminal law that arise due to the implementation of individual fundamental rights and freedoms. This object of the specified crime is called public relations arising from constitutional rights and freedoms of the citizens ${ }^{30}$. There is also a perception that generic object of crimes forseen in Chapter $\mathrm{V}$ of the Special Part of the Criminal Code of Ukraine including Art. 176 of the Criminal Code are constitutional rights and freedoms of man and citizen.

However, we believe that epy generic object of crime according to the Art. 176 of the Criminal Code of Ukraine is an intellectual property right and therefore it is advisable to merge the specified norm and art. 177, 2031, 229, 231, 232 and 2321 of the Criminal Code of Ukraine in a separate section of the Special Part of the Code, calling it "Crimes against Intellectual Property” and placing between sections VI „Crimes against property” and VII „Crimes in the Sphere of Economic Activity|. The immediate object of the crime under

27 Штефан А.О. Кримінально-правова охорона авторського права і суміжних прав: актуальні питання // Теорія і практика інтелектуальної власності. - 2011. - №1. - С. 37-45.

28 Нерсесян А.С. Кримінально-правова охорона прав інтелектуальної власності: автореф. дис. канд. юрид. наук // Ін-т держави і права ім. В.М. Корецького. - К., 2008. - 22 с.

29 Мельник М.І. Науково-практичний коментар Кримінального кодексу України від 5 квітня 2001 року зі змінами та доп. / За ред. М.І. Мельника, М.І. Хавронюка. - К. : Каннон, A.C.K., 2010. - 1104 C.

30 Святоцький О.Д. Інтелектуальна власність в Україні: правові засади та практика: наук. практ. вид.: у 4-х т. / За заг. ред. О.Д. Святоцького. - Т. 1.; Право інтелектуальної власності / С.О. Довгий, В.С. Дроб'язко, В.О. Жаров та ін.; За ред. М.В. Литвина, С.О. Довгого. - К., 1999. C. $21-24$. 
Art. 176 of the Criminal Code of Ukraine is property rights of copyright and related rights in the form of exclusive rights to authorize or prohibit the use of the works, computer programs, databases, performances, phonograms and broadcasts. Mens rea in accordance with the Art. 176 of the Criminal Code of Ukraine is characterized by deliberate form of fault as a direct or indirect intent. It should be noted that the subject of the crime can be any sane individual who has reached sixteen years to the day of the crime including the author of the product creativity in case of violation of previously alienated property to another person the right to work, the computer program, database, sound recording, videohram, program broadcasting.

Actus reus in accordance with the Art. 176 of the Criminal Code of Ukraine is committing illegal reproduction or distribution of copyright and related rights and other intentional violations of property rights of the author's works, computer programs, databases, phonogram, videogram, broadcasting organization in accordance with the Art. 15, 39-41 of the Law of Ukraine „On Copyright and Related Rights" and material damage as a mandatory feature of actus reus under Art. 176 of the Criminal Code of Ukraine is the damage caused only by a violation of property rights of copyright and related rights.

We conclude that the current norm today on criminal liability for infringement of copyright and related rights the material injury must be understood as the value of impaired property rights of authors, performers, phonogram, videogram, broadcasting organization. The lack of content definition by a legislator of the expression "material harm" is not conducive to the proper application of Art. 176 of the Criminal Code of Ukraine by the pre-trial and trial ${ }^{31}$.

Studying the situation with the spread of counterfeit products online indicates that the application to offenders only criminal sanctions doesn't allow to make operational impact on Internet sites that distribute counterfeit products. Therefore in our opinion the most effective way to combat copyright infringement on the Web is the application to the respective owners of Internet sites of administrative influence disabling and blocking websites that distribute counterfeit products on Internet access.

31 Гулкевич В.Д. Кримінально-правова охорона авторського права і суміжних прав : автореф. дис. ... канд. юрид. наук : 12.00.08. - Львів. -2008. - 20 с. 


\section{COMPENSATION OF DAMAGES FOR COPYRIGHT INFRINGEMENT IT-SPHERE}

The information and telecommunications network has become an integral part of life for millions of people. Anonymity and practically uncontrolled access to the network led to the fact that one of the most acute problems on the Internet was the problem of violation of copyright and related rights. Proceeding from this, the issue of distribution of responsibility between direct offenders and providers that provide the possibility of committing offenses, establishing subjects, further commitment to compensate losses to the victims, as well as establishing an order of compensation for property (non-property) harm for offenses in the network became urgent.

So, Article 16 of the Civil Code of Ukraine guarantees each person the right to apply to the court to protect his property or personal non-property right and interest. Protection of civil rights, including copyright, by the court is carried out in accordance with the established procedure by: recognition of law; the recognition of the transaction as invalid; termination of the infringing right; restoration of the situation that existed before the violation; compulsory performance of duties in kind; change in legal relations; termination of legal relations; compensation for damages and other ways of reimbursing property damage; compensation of moral (non-property) harm; recognition of illegal decisions, acts or omissions of the central executive authority and local government.

In addition, the possibility of civil-law protection of copyright is established art. 432 of the Civil Code of Ukraine, according to which every person has the right to apply to the court for the protection of his intellectual property right under art.16 of the Civil Code of Ukraine.

Article 52 of the Law of Ukraine „On Copyright and Neighboring Rights” establishes that if any person violates copyrights and related rights, noncompliance with the terms of use of works and other objects of copyright and related rights specified by the agreement, as well as other violations of personal rights

Non-property and property rights holders of copyright, in particular, have the right:

- file claims for compensation for moral (non-property) harm;

- file claims for damages (pecuniary damage), including lost profits or collection of income received by the violator as a result of a violation of copyright, or payment of compensation'.

Про авторське право і суміжні права: Закон України від 23.12.1993 р. // Відомості Верховної Ради України. - 1994. - № 13. - Ст. 64. 
The most effective ways to protect copyrights are compensation of damages, recovery from the infringer of illegally obtained income or payment of compensation to them. In this case, the property interest of the victim is satisfied at the expense of monetary compensation for property damage caused to him. Such compensation may be either directly related to the amount of damage caused (compensation of damages), or is associated with it only indirectly (collection of illegal income), or in general is relatively independent of it (payment of compensation). The current legislation provides for recovery from the infringer of losses in full. In addition, the victim has the right to choose the most expedient way of compensation for harm, which contributes to the effectiveness of protection of his affected property interests. At last the right to compensation of losses can be used by all owners of copyrights, including the persons acquiring these rights under contracts².

It should be noted that the concept of compensation for harm during the last decade has undergone significant changes. If the previous civil law was oriented to determining the consequences of "causing, causing harm," the consequences of a civil offense, now the first priority is clearly the harm reduction task. The fulfillment of this task is at the center of attention regardless of what was caused by the occurrence of harm: an offense, the actions of the victim himself or objective factors of the surrounding reality (events of a spontaneous or social nature, etc.) ${ }^{3}$.

According to Article 52 of the Law of Ukraine „On Copyright and Neighboring Rights", the main form of compensation for damage caused to the victim is compensation for damages. Losses are understood as expenses related to a person whose rights are violated, loss or damage to his property (real damage), as well as non-receipt of income that a person could receive under normal conditions of civil turnover, had his rights not been violated (loss of profit). As a general rule, losses are reimbursed to a certain extent. The costs of legal assistance in the protection of violated copyright are also subject to reimbursement.

The victim has to justify the amount of damage caused. He also accounts for the very fact of his copyright infringement, as well as the causal connection between the violation of his rights and the losses incurred. As for the subjective condition of liability, the violator of copyright is convicted until proven otherwise. At the same time, Article 52 of the Law provides

\footnotetext{
Тимофеенко Л. П.Охрана прав на интеллектуальную собственность. - К., 2004 - С. 100.

3 Ківалова Т. С. Проблемні питання встановлення співвідношення наслідків порушення договору та зобов'язань відшкодування шкоди // Часопис цивілістики. Науково-практичний журнал. - 2008. - № 6. - С. 14.
} 
that when determining the amount of loss, moral (non-property) harm, the court must proceed from the nature of the violation, property and moral harm caused to a person having copyright and (or) related rights, as well as from a possible Income that this person could receive. This statement of the question, of course, deserves respect, but in practice it is extremely difficult to apply and sometimes impossible $e^{4}$.

The criteria provided by the Law of Ukraine „On Copyright and Related Rights", which are taken into account in determining the amount of damages to be reimbursed to a person whose rights are violated, are of a general nature and do not allow the full restoration of violated copyrights. In connection with this, the following special criteria are formulated, which are determined by the specifics of copyrights, must be taken into account when determining the damage caused by their misuse: the time and method of misuse of copyright objects; rights, violated (property and non-property) circle of persons who were able to use the work as a result of its illegal distribution; a person who is harmed (author, his successors).

As a general rule, losses are collected in cash. At the same time, one should keep in mind that the current legislation allows transfer of counterfeit copies of a work to the owner of copyright in accordance with his demand, at the expense of which the losses incurred can be fully or partially covered.

The damage to the author can be caused both in the presence of the contract and in its absence. In our opinion, in the first case there are no noticeable features of harm recovery in the IT sphere.

But it is worth noting that at the present stage of the development of the state, information warfare has a significant impact, which can be defined as a phenomenon in which a comprehensive impact on the information sphere is carried out, aimed at creating conditions for information warfare, or acts as an independent factor that forces the conflicting parties to refuse From the planned political, economic or other purposes. At the same time, due to virus attacks, as one of the methods of information warfare, not aimed at a certain circle of people, but more often aimed at mass effects, are characterized by causing significant material and moral harm to a wide range of persons. Such harm arises from an insurmountable event and the subject's issues are obliged to compensate the damage inflicted to the affected parties, in such cases, remains unclear.

As for property non-contractual harm, it is most often in the IT field it is inflicted by piracy and plagiarism, the consequences of which were discussed in the previous chapters of this monograph. Therefore, we will

4 Вінаєва К. Авторські та суміжні права: аспекти цивільно-правового захисту. - Режим доступа: http://www.yur-gazeta.com/article/1172/ 
only recall the general principles of compensation for harm under the rules of Chapter 82 of the Civil Code of Ukraine, and we will only dwell on the specifics of compensation for extra-contractual harm in this area.

So, the main principles of compensation for property damage are:

1) the occurrence of property damage;

2) property damage is subject to compensation in full by the offender;

3) only those damages caused by unlawful and guilty actions shall be compensated for the losses caused;

4) between the unlawful conduct and the harm of the come-on, there must be a causal relationship.

The most problematic and most important is the compensation of moral (non-property) harm.

This is due to the fact that at the present stage of development of the world community the problem of human rights and freedoms is one of the most urgent. In this direction, a number of international regulatory and legal acts have been adopted that define a person as the highest value of society, and the proper provision of his rights and freedoms is the main duty of a democratic state. It is not for nothing that the Preamble to the Universal Declaration of Human Rights states that the recognition of the inherent dignity of all members of the human family and their equal and inalienable rights is the foundation of freedom, justice and universal peace, and the Preamble to the International Covenant on Economic, Social and Cultural Rights Proclaims that all human rights „flow from the inherent dignity of the human person”.

Similar ideas are reflected in the Constitution of Ukraine, which grants citizens the right to compensation for moral (non-property) harm.

Compensation of moral (non-material) harm according to the norms of the Constitution of Ukraine, as norms of direct action (Article 8), determines the main principle of state policy on the priority of universal values, protection of rights and legitimate interests of legal entities of all forms of ownership. The novelty of this principle is that the legislation of the Ukrainian SSR and the former USSR did not provide for compensation for moral (non-material) harm. Currently, this legal institution is being formed in Ukraine, and it becomes the focus of attention among the obligations on compensation for harm, since the problem of its reimbursement concerns, first of all, the protection of the absolute rights of individuals and legal entities that form the basis of civil legal relationships.

The problem of compensation of moral (non-property) harm, as one of the types of harm that can be inflicted on an individual or legal entity, exists long ago and in all countries. For its solution, as a rule, three variants were proposed: 
Full denial of compensation for moral (non-property) harm;

Compensation only in certain cases determined by law;

Compensation in all cases without exception.

In the current Civil Code of Ukraine there is no definition of the concept of moral (non-proprietary) harm. It is believed that this is correct, since every approach (scientific and legislative) with the aim of its disclosure will be incomplete. So, it would be incomplete and the definition of such a concept in the same Code. According to Article 23 of the Civil Code of Ukraine, moral harm can be manifested in: 1) the physical pain and suffering that an individual experienced in connection with an injury or other damage to health; 2 ) in mental suffering that an individual has experienced in connection with unlawful conduct in relation to himself, members of his family or close relatives; 3) in mental suffering that an individual has experienced in connection with the destruction or damage to his property; 4 ) in the humiliation of the honor and dignity of an individual, as well as the business reputation of an individual or legal entity.

From the above provisions, we can conclude that „moral (non-property) harm is physical or mental suffering caused to an individual by unlawful decisions, actions or omissions (Part 1, Article 1167 of the Civil Code), which violate her personal non-property rights or encroach on the proper To an individual a property, as well as a humiliation of honor, dignity, business reputation of an individual or a legal entity.

Therefore, the compensation of moral (non-property) harm is the commission of a person who has suffered harm, actions aimed at removing from her negative feelings (physical suffering) or feelings (mental suffering) caused by humiliation of his dignity, honor and business reputation.

The application of this method of protection of civil rights (clause 9, part 2, article 16 of the Civil Code of Ukraine) is aimed at the full restoration or weakening of negative feelings.

Full-fledged protection of the rights of everyone to compensation for moral (non-material) harm at the level of the competent courts of Ukraine is ensured, and after using all national remedies - by international judicial institutions or relevant bodies of international organizations, of which our state is a member or participant 5 (Article 55 of the Constitution of Ukraine) ${ }^{5}$.

Compensation for moral harm is relatively new and at the same time one of the most effective ways to protect civil rights. Compensation for moral harm has a number of peculiarities, which, first of all, consist in clearly defined unlawful behavior.

5 Паліюк В. П. Міжнародні судові установи і захист прав людини та основних свобод. [навчально-практичний посібник]. - Миколаїв: Атол, 2006. - С. 25-81. 
For many years in the domestic civilization it was considered that non-property damage can not be estimated, therefore it is not subject to reimbursement.

Moral damage is understood as moral and physical suffering caused to a citizen as a result of infringement of intangible goods (life, health, honor, dignity, business reputation, inviolability of private life, etc.) belonging to him from birth or by law. ${ }^{6}$.

The peculiarity of moral harm lies in the fact that it has non-property character and can be the physical pain and / or suffering of an individual, as well as other negative consequences of non-property nature, was caused by the humiliation of honor, dignity of a physical person and business reputation of a physical and legal person, As well as other unlawful acts. A specific specificity is in the fault of the causer. As a general rule, the moral damage caused is compensated in the presence of the fault of the causer. However, compensation for moral damage can be carried out and regardless of the guilt of the person who caused it.

Specificity of compensation for moral harm in non-contractual relations is that it comes as a consequence of the violation of the absolute legal relationship and is therefore regulated, in addition to general provisions of civil law, by norms, specifically refer to compensation for losses in the field of intellectual property. At the same time, compensation for moral harm is a guaranteed minimum of protection of rights and obligations of subjects of civil law relations. The contract may increase the liability of the causer of moral (non-property) harm in comparison with the tort. This circumstance is caused by the fact that contractual liability is the responsibility for the violation of the existing obligation, that is, existing between the parties.

For the emergence of obligations to compensate for the moral (nonproperty) harm arising from tort, it is necessary to combine the following conditions: 1. The existence of moral (non-property) harm. 2. The wrongfulness of the actions of the causer of moral (non-material) harm. 3. Causal connection between the wrongful conduct of the causer and moral (non-material) harm. 4. Wines in causing moral (non-property) harm.

The totality of the above conditions and forms a common ground for imposing civil liability for causing moral (non-property) harm. They are called generic, since for the emergence of obligations from causing this type of harm their presence is necessary in all cases, and unless otherwise established by a special law.

As a general rule, moral damage is compensated to the person who has the right to demand such compensation. However, in cases directly provided

6 Заїка Ю. О. Українське цивільне право: навч. посіб. - К. : Істина, 2005. - 312 с. 
by law, the perpetrator of moral harm and the person responsible for it may not coincide. In the countries of Europe, the United Kingdom and the United States, the rights holder is increasingly demanding responsibility for hosting providers in connection with violation of copyrights and related rights carried out by his clients. The position of responsibility on the provider would speed up the process of identifying and suppressing illicit activities in the network, including by denying access to offenders. At the same time, bringing providers to account for non-material harm caused by providers would reduce procedural costs, compared with the costs of making claims against individual offenders-users of the network. But, the imposition of responsibility for violation of copyright and related rights on the Internet to the provider in full is impractical, because often it is only an indirect relation to the offense.

Persons entitled to compensation for moral (non-proprietary) harm also include „subjects of copyright”. The last are the persons who own subjective copyright in respect of the work: citizens of Ukraine and foreign citizens, their heirs or successors, legal entities, as well as the state of Ukraine as a whole. Legislation of Ukraine distinguishes between primary and derivative copyright. The creators of the work - „author" and „co-author" are valid carriers of the primary copyright.

In accordance with Art. 44 of the Law of Ukraine „On Copyright and Related Rights” violator of copyright is obliged to compensate moral (nonproperty) harm to the owners of copyright and related rights.

Only the owners of personal non-property rights, that is, the authors themselves, can claim moral compensation as a general rule.

For the emergence of obligations to recover moral (non-property) harm, it is necessary: first, that the actions were illegal, that is, they did not comply with the law or regulations; Secondly, they inflicted moral (non-material) harm to a physical or legal person.

The causal link between wrongful conduct (action or inaction) and moral (non-material) harm is an important condition for liability for the harm done. And this is not accidental, since the absence of causation excludes the responsibility of the causer. Moreover, the absence of a causal link means that moral (non-property) harm is a consequence not of its unlawful behavior, but is caused by some other reasons.

When deciding whether to bring a person to civil liability for causing moral (non-proprietary) harm, great importance is given not only to the fault of the causer, but also to the fault of the victim. At the same time, the legislation of Ukraine provides the victim with a number of procedural and material advantages to the causer of moral (non-property) harm. The most important of them is the presumption of guilt, the causer, whereas 
the fault of the victim must be brought by the defendant. Similarly, the law differently assesses the consequences of the behavior of the causer of moral (non-property) harm and the victim. In particular, to impose responsibility on the perpetrator of this harm, as a general rule, his guilt is sufficient to any extent. The fault of the victim is expressed in the form of simple negligence and never affects the decision of the issue of the conditions of liability for the moral (non-material) harm caused.

In practice, there are often issues related to the amount of compensation for moral damage. Unfortunately, the Civil Code of Ukraine leaves the issue of determining the amount of compensation for moral harm without proper legal regulation. It is stipulated that moral damage is compensated by money, other property or other means. It is stipulated that moral damage is compensated by money, other property or other means. By the amount of monetary compensation for moral damage, the legislator notes that it is determined by the court depending on the nature of the offense, the depth of physical and mental suffering, the deterioration of the ability of the victim or depriving him of the possibility of their implementation, the degree of guilt of the person who caused moral damage if the fault is the basis for reimbursement, and also taking into account other circumstances of significant importance. And this means that when determining the size of such compensation, neither the court nor the parties will have any legislative prerequisites for its determination.

In Ukraine, it is not only not established clear methods for calculating the amount of moral damage, but also the lower or upper limit, as benchmarks, and causes the court to take into account the requirements of reasonableness and justice when determining the amount of compensation for moral harm. Moral harm is compensated regardless of property damage, subject to reimbursement, and is not related to the amount of this compensation. As a general rule, the calculated amount of moral damage is reimbursed at a time, unless otherwise established by the contract or law?

If the gross negligence of the victim himself contributed to the emergence or increase of the moral (moral) harm caused to him, then depending on the degree of the fault of the victim (and if the fault of the injurer - and depending on the degree of his guilt), the amount of compensation, unless otherwise provided by law, should to be reduced or to compensate for harm should be denied.

The amount of property damage is objectively expressed as the price of a thing or the amount of income. However, the legislator refused to regulate

7 Цивільне право України: навч. посіб. [ Ю. В. Білоусов, М. Л. Митрас, С. Д. Гринько та ін.]; за ред. Р. О. Стефанчука. - К. : Правова єдність, 2009. - С. 457. 
the volume (size) of the moral (non-material) harm by granting this right of the court. It follows that there is no compensation for moral (non-property) harm until the court has determined it, depending on the depth of the physical and mental suffering of the victim, the deterioration of the ability of the victim or the deprivation of his ability to implement them, the degree of guilt of the offender Copyright, property status of the harm-bearer, and also taking into account other circumstances of significant importance. When determining the amount of compensation, the requirements of reasonableness and fairness are taken into account. Naturally, such a determination of the amount of compensation is not unambiguous.

Moral damage can not be compensated in full, because there are (and can not be) exact criteria for the material expression of spiritual pain, tranquility, honor, and dignity of the individual. Any compensation of a moral school can not be adequate to actual suffering, therefore any size of it can have a purely conditional expression, especially if such compensation concerns a legal entity. However, in any case, the amount of compensation should be adequately caused to moral damage, and the requirements of reasonableness and fairness must be taken into account.

When determining the amount of moral damage to be reimbursed, it is necessary to be guided firstly by general criteria to which it is possible to refer: universal values. On the one hand, these are the criteria that determine the subjective feelings of the victim, for example, honor, dignity, authority. They are evaluated only by the victim, the degree of his perception of the trauma and its consequences. On the other hand, these are the criteria that characterize the external manifestation of the consequences of health damage. Here, moral harm is expressed in violation of the habitual for a particular person lifestyle, caused by an accident. Moral harm can also be expressed in a real loss to victims of the opportunity to communicate normally with friends, acquaintances, live a full life. Essential criteria for determining the amount of moral damage are the special criteria due to the peculiarities of the object and the content of the rights of subjects of intellectual property rights.

Judicial practice shows that a differentiated approach is fair and legally more correct than a complete disregard for the individual characteristics of a person who is morally harmed ${ }^{8}$.

Therefore, in the case of recovery of compensation instead of losses or income received, the court must determine their scale (in other words, indicative losses), and not the exact figure, namely: establish by appropriate means of proof the existence of a lost profit, consisting of a

8 Манукян В. И. Моральный вред: право, практика, опыт. -К. : Истина, 2008. - С. 147. 
possible remuneration for similar use under a license agreement, Which was either established by this right holder under previous transactions, or is an established practice in this field; profit from the sale of copies of the work, which was predicted, but was not received due to the proliferation of counterfeit products.

Given that the law does not establish the minimum and maximum amount of property damage, it is considered necessary to establish at a legislative level the minimum amount of payment of moral damage caused by the misuse of copyright, should be no less than the minimum amount of compensation provided for by the Law of Ukraine „On Copyright and Related rights,,

In the case of manufacturers of technical devices, providers who serve their users for infringement of copyrights of third parties, such principles as participation in violation and responsibility for the activities of other persons are taken into account in accordance with US common law.

The principle of "complicity in violation” is based on bringing to justice the one who supports third parties in the implementation of illegal actions, despite the fact that he knows that this is not legal. When prosecuted on the principle of "responsibility for the activities of other persons" it is not necessary that such a person should know that the actions performed by third parties are unlawful. But at the same time, it will be enough here already that such a person can be monitored and the actions of the infringer of rights are monitored, as the financial benefit of committed unlawful acts can be obtained, as in the case of the Internet service liability that was mentioned above.

Summarizing the above, we should pay attention to the fact that the Law of Ukraine „On Copyright and Neighboring Rights” provides for the possibility, instead of compensation for damages, to demand payment of one-time compensation. The advantages of compensation are: there is a minimum amount that can be guaranteed to be paid to a subject whose rights have been violated; secondly, it is necessary to bring only the fact of copyright infringement. However, the negative point is the lack of clear criteria on the basis of which the court determines the amount of compensation. Unlike compensation for compensation of damages, a person whose rights are used improperly must prove both the fact of causing losses and their size. 


\section{List of Authors:}

Kharytonova Olena Ivanivna - Doctor of Law, Professor, Corresponding member of the National Academy of Legal Sciences of Ukraine, Honored Worker of Scienceand Technics of Ukraine, Head of the Department of Intellectual Property Law and Corporate Law of the National University "Odessa Law Academy": Section 1 (co-authorship with Kharitonov E.O.), Section 9 (co-authorship with Pozova D.D.)

Kharytonov Yevhen Olehovych - Doctor of Law, Professor, Corresponding Member of the National Academy of Legal Sciences of Ukraine, Honored Worker of Scienceand Technics of Ukraine, Head of the Department of Civil Law of the National University "Odessa Law Academy": Section 1 (co-authorship with Kharitonova O.I.), Section 7 (co-authorship with Sukha Yu.S. and Heyko M.O.);

Ulyanova Halyna Oleksiyivna - Doctor of Law, Associate Professor, Vicerector for Scientific Work, Professor of the Department of Intellectual Property Law and Corporate Law of the National University "Odessa Law Academy": Section 13.

Baadzhy Nataliya Pylypivna - Candidate of Legal Sciences, Associate Professor, Associate Professor of the Department of Intellectual Property Law and Corporate Law of the National University "Odessa Law Academy": Section 13(co-authorship with Spasova K.I.);

Bernaz-Lukavetska Olena Mykhaylivna - Candidate of Legal Sciences, Associate Professor, Associate Professor of the Department of Civil Law of the National University "Odessa Law Academy": Section 11 (co-authorship with Podsyadlo R.P.);

Heyko Myroslava Olehivna - Section 7 (co-authorship with Kharitonov E.O. and Sukha Yu. S.);

Hrihoryants Halyna Ihorivna - Candidate of Legal Sciences, Assistant Professor of the Department of Intellectual Property Law and Corporate Law of the National University "Odessa Law Academy": Section 12;

Davydova Iryna Vitaliyivna - Candidate of Legal Sciences, Associate Professor of the Department of Civil Law of the National University "Odessa Law Academy": Section 8;

Kyrylyuk Alla Volodymyrivna - Candidate of Legal Sciences, Associate Professor, Associate Professor of the Department of Intellectual Property Law and Corporate Law of the National University "Odessa Law Academy": Section 14;

Mykhaylyuk Halyna Olehivna - Candidate of Legal Sciences, Assistant Professor of the Department of International Law and Special Legal Disciplines of the National University of "Kyiv-Mohyla Academy": Section 5; 
Omelchuk Oleksandr Serhiyovych - Candidate of Legal Sciences, Associate Professor, Associate Professor of the Department of Civil Law of the National University "Odessa Law Academy": Section 2;

Pozova Dina Dmytrivna - Candidate of Legal Sciences, Assistant Professorof the Department of Intellectual Property Law and Corporate Law of the National University "Odessa Law Academy": Section 3; Section 9 (co-authorship with Kharitonova O.I.);

Sukha Yuliya Serhiyivna - Candidate of Legal Sciences, Associate Professor of the Department of Civil Law of the National University "Odessa Law Academy": Section 7 (co-authorship with Heyko M.O., Kharitonov E.O.);

Fedorov Valentyn Andriyovych - Candidate of Legal Sciences, Associate Professor of the Department of General Theoretical Jurisprudence of the National University "Odessa Law Academy": Section 6;

Spasova Kateryna Ivanivna - Post-graduate student of the Department of Civil Law of the National University "Odessa Law Academy": Section 13(co-authorship with Baadzhy N.P.);

Fasiy Bohdan Volodymyrovych - Post-graduate student of the Department of Civil Law of the National University "Odessa Law Academy": Section 4, Section 10 (co-authorship with Tolmachevska Yu.O.);

Podsyadlo Roksolana Petrivna - Master's Student of the Faculty of Civil and Commercial Justice of the National University "Odessa Law Academy" Section 11 (co-authorship with Bernaz-Lukavetska O. M.);

Tolmachevska Yuliya Olehivna - Student of the Faculty of Civil and Commercial Justice of the National University "Odessa Law Academy" - Section 10 (co-authorship with Fasiy B.V.). 
Izdevnieciiba "Baltija Publishing"

Valdeku iela 62 - 156, Rīga, LV-1058 www.baltijapublishing.lv

lespiests tipogrāfijā SIA "Izdevniecỉba "Baltija Publishing" Parakstīts iespiešanai: 2017. gada 21. aprilī Tirāža 100 eks. 